\title{
An Environmental Plan for Lagos, Nigeria
}

\author{
David J. Edelman (Corresponding author) \\ School of Planning, University of Cincinnati \\ PO Box 210016, Cincinnati, OH 45221-0016, USA
}

Tel: 1-513-556-2378Ｅ-mail: david.edelman@uc.edu

Received: February 24, 2015 Accepted: March 12, 2015 Published: March 25, 2015

doi:10.5296/ijssr.v3i1.7157～URL: http://dx.doi.org/10.5296/ijssr.v3i1.7157

\begin{abstract}
This paper focuses on the practice of Urban Environmental Management (UEM) in developing countries, which both face more immediate problems than the developed world and have fewer resources to deal with them. It is the report of a graduate level workshop that took place at the School of Planning, College of Design, Architecture, Art and Planning, University of Cincinnati, USA from August through December 2014. The objective of the workshop was to prepare students to work overseas in data-poor environments as professional consulting planners. Several lectures were given to set the framework for the class of 14 students to operate in sector-level working groups or teams preparing a 5-year plan to help solve the urban environmental problems of Lagos, Nigeria, the largest, most environmentally complex metropolitan area in Africa, utilizing a real-world data base and a limited budget. This project culminated in the preparation of a professional quality plan. The instructor, who has over thirty years of planning experience in developing countries, including Nigeria, attempted to create an atmosphere within the project that duplicates the actual conditions of carrying out such a consultancy.
\end{abstract}

Keywords: Urban environmental management, UEM, environmental planning, planning for development, Lagos

\section{Introduction}

This paper is a case study of Urban Environmental Management (UEM) in developing countries that summarizes the report of a graduate level workshop that took place at the School of Planning, College of Design, Architecture, Art and Planning, University of Cincinnati, USA from August through December 2014. The objective of the workshop was to prepare students to work overseas in data-poor environments as professional consulting planners. Several lectures were given to set the framework for the class of 14 students to 
operate in sector-level working groups or teams preparing a 5-year plan to help solve the urban environmental problems of Lagos, Nigeria, the largest, most environmentally complex metropolitan area in Africa, utilizing a real-world data base and a limited budget. The 7 working groups or sectoral teams (Poverty Alleviation, Industry, Sewage and Solid Waste, Transportation, Energy, Water and Finance) conducted intensive internet and library research and wrote sectoral reports, which were combined to form the Environmental Plan for Lagos, the largest, most environmentally complex metropolitan area in Africa at 21 million inhabitants (Campbell, 2012).

\section{Poverty Alleviation}

\subsection{Introduction}

Lagos is one of the fastest growing economies in the developing world, with many tech companies and large industries choosing to locate new facilities within the city. However, despite its economic vibrancy and increasing wealth, poverty remains a major issue. This city has 11 identified slums, with populations ranging from approximately 15,000 to 633,000 inhabitants (Selvanavagam, 2012). While the city's most recent housing plan includes creation and management of affordable housing for its underserved poor populations, their needs are still not being met. New development is receiving priority within the slums because some of them are located upon prime real estate, and many residents are being ousted from their homes. The major impediments facing the process of poverty alleviation in Lagos include: lack of formal financial services for the poor, fluctuating food prices, natural disasters, and violent conflicts between multiple socioeconomic groups. Nigeria is the African country with the largest urban population, and has a significantly large percentage of that population living in slums (GRID - Arendal, 2011). Because Lagos is the largest city within Nigeria, it is clear that it is a major contributor to the entire continent's slum population, and that poverty and housing conditions are a major issue within the city itself.

The National Planning Commission of Nigeria has identified multiple variables that contribute to the significant percentage and continuity of issues of poverty within the country. One factor greatly affecting the amount of poverty within the country is the widening income gap. Many government policies do not support redistribution of wealth, therefore making the rich richer and the poor poorer. This also can contribute to a decrease in the standard of living, particularly for those who fall into lower-income brackets. Some other key issues contributing to poverty within Nigeria include: government corruption, social conflicts, gender inequality and indebtedness to multiple countries (NPC, 2004).

\subsection{State of Housing Conditions in Lagos}

A major obstacle to sustainable housing and urban development in most developing countries is the spontaneous urbanization of rural - urban migration, which makes the high grade and properly managed housing ideal for sustainable communities infeasible. A large percentage of Nigeria's population lives in poverty-stricken conditions, and the current supply of housing in Lagos is simply not sufficient to provide for its continuously increasing population. Thus, housing remains a social responsibility of the Lagos government, and increasingly, the health 
of Nigeria, and the prosperity of it citizens will depend on the level of success in improving the housing sector.

\subsection{Programs for Poverty Alleviation}

\subsubsection{Land Titling Program}

A problem that currently plagues most Lagos residents living in poverty is that they lack legal ownership of their land. In many cases, those living within the slums have been on the land for a number of years, never gaining legitimate property rights. Many of the city's largest slums are located on land that is considered prime real estate for new developments, and the government has forced families out and demolished homes in order to make economic advances. If these citizens are given a more efficient and accessible system in terms of property ownership, they may have a stronger defense against these government interventions. In order to tackle the issue of poverty in the city, it is essential that all people are given opportunities to gain these rights and establish legal holdings.

Lagos can turn to the Philippines for a successful example of a land-titling program geared towards slum dwellers. The Philippine government established the Land Acquisition and Management Project (LAMP2) in order to provide those in poverty with equal opportunities for land ownership. The goals of this project were to secure land tenure and property rights for people who had been illegally occupying land within the country for over a year's time. By making the process of titling easier, more people would be inclined to secure their land and to maintain and improve it as well. The legal process was made simpler, so that the average person living within the Philippines would be able to understand and follow it, and the process was also made quicker and more efficient. Many people had foregone land titling previously because the process had been plagued by red tape and took a significant amount of time. The program received initial funding through the World Bank, and technical assistance from AusAID. Upon recent assessment, the majority of municipalities within the country now have $70-85 \%$ of their land registered and titled (World Bank, 2013).

It is proposed that the government of Lagos follow this model for an initial 5-year period to put in place policies that will provide adequate support for simple and accessible land management services. In these first 5 years, the government would need to create a governing board, and develop a framework that will prioritize legislation and regulations to guide the development and land adjudication processes. This governing body should formulate a plan that will guide it in future policy implementation and creation for up to 15 years. This plan should have support from all representatives and affected stakeholders.

Following the generation of an institutional framework and management plan, Lagos' focus should be on improving tenure security. This can be done by increasing communication between the government and stakeholders, and by raising community awareness about the changing land titling process. The governing body should establish a program that increases this public education and acts as a forum for community discussion, allowing the needs and concerns of the population to be addressed appropriately. Along with a public awareness campaign, it is essential that the governing body remain up to date on the mapping of 
available properties and surveying of the land. During the initial phase of this program, it is necessary that surveys be conducted to allow for accurate adjudication of property rights.

The goal within the first 5 years would be to have $40 \%$ of the Lagos slum population gain titles and property rights to their land. By implementing city wide policies and governing bodies to streamline the process of adjudication, it is expected that most residents who are currently informally occupying land within the slums will be interested in, and apply for, titles to the land, which they have occupied for years. This will give them more responsibilities and rights as landowners, which can help to reduce the number of families living in poverty within the city.

\subsubsection{Tiny Abod Temporary Homes}

There is an established type of affordable housing, which can help a vast number of people in a limited amount of time. The Chairman of the Board of BSB Design, Doug Sharp, has stated, "Abod is the opportunity for us to give something back to society. It is time to realize our dream of making the world a better place in which to live (TinyHouseTalk, 2010).” These shelters are lightweight and composed of corrugated metal and translucent plastic panels, which can be used for establishing light. Natural lighting is helpful in areas, which don't have good access to electricity. The Tiny Abod shelters will have gutters to aid in directing rainwater away from the homes. The shelters are very portable and can be shipped anywhere on this planet. Tiny Abod structures are sustainable and can be customized to fit an individual's needs. All the essentials that can be found in an average sized home can be found in these Tiny Abod structures. These shelters have toilets, which will help in sanitation, as well as kitchens and opportunities for end walls, loft expansion, etc. Special doors can also be added to the core structures. The unique design allows individuals to have their own bed and room to maneuver.

\subsubsection{Stakeholders and NGOs}

Funding for the project is proposed to come from the United Nations (UN), the University of Nigeria, as well as NLE Architects of Lagos. These organizations together will provide the expertise and resources so that the Tiny Abod structures can be fully implemented. The UN is constantly supporting efforts to combat poverty on various levels, and a core UN focus is to provide higher standards of living through education, full employment and social progress through development. Around $70 \%$ of the work, which the UN contributes, is geared towards accomplishing such efforts. UN agencies provide technical support and other forms of functional help to countries around the world. Thus, it is suggested to ask United Nations Habitat in Nairobi for approximately 80 million dollars for the 5-year start up program. Ultimately, the monies from the UN will aid in the primary cost of purchasing the Tiny Abod prototypes from BSB design (un.org, 2014). Working with the UN would also allow for sufficient publicity and show Lagos in a positive light through national advocacy.

It is worthwhile to have involved an academic institution such as the University of Nigeria, which can foster learning, as well as provide human resources for this project and help generate funds. It is of note that the program of the University of Nigeria that would be 
involved comes from research in the decision theory of human behavioral patterns. While, architects currently dominate the building industry, the idea is to work with students and faculty of the University of Nigeria, as well as the residents of the Iwaya community and volunteers, to form a group with the ability to work cohesively together.

It is also necessary, of, course, to work with experts as facilitators, as well as to provide design alternatives and expertise. Founded by Kunle Edeyemi, NLE Architects specialize in architectural design and planning. This firm would be a suitable designer and NGO for this project because of its prior experience with designing housing structures for slum development. NLE has also designed a water community project. Thus, NLE could help develop the most strategic way to implement the Tiny Abods which would suit the element of water (NLE, 2012).

\subsubsection{Original Abod Design Set Up}

Exhibit 1 below illustrates the Tiny Abod structure's construction, which is very easy and usually takes no more than a day for one installation. As mentioned previously, this program will be conducted in collaboration with BSB design, which currently has units available for shipment from South Africa.

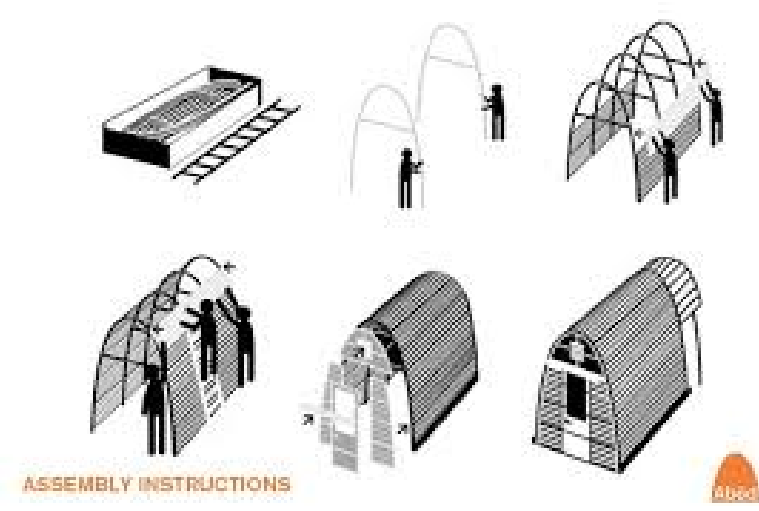

\section{Exhibit 1. Abod Home Construction}

Source: Laylin, 2012.

\subsubsection{Build Change - Resilient Structures}

While the Tiny Abod homes are a quick solution to the housing issue within Lagos' slums, the population will also need structures that are more durable and resilient, particularly in Makoko, where water is everywhere, and flooding is often a concern. Build Change, a U.S. based non-profit organization works with developing communities to build resilient buildings out of sustainable, durable higher-quality materials. They have worked in areas that are prone to hurricanes, earthquakes, flooding and other natural environmental challenges. Their services also extend into education, i.e., training the local people to create durable construction materials and build the structures themselves. They emphasize the education of women and encourage their interests in engineering and architecture.

One example of the work that Build Change has done in developing countries can be seen in 
the Philippines (Build Change Philippines, 2014). Following the crushing impacts of its many earthquakes and typhoons, the country has experienced great damage to homes and other buildings. Build Change has addressed this issue by working with locals to rebuild their towns. They used two models, one made of brick and mortar and one of wood, which were built in a more sustainable and durable way that would better handle any future natural disasters. The models were explained and demonstrated to local community members, who could then use them for future developments. By teaching the community how to construct their own buildings and how to create and use higher quality building materials, Build Change was able to reduce the costs of construction and labor, as well as provide residents with a resilience strategy.

In the case of Lagos, this project would first focus on community buildings, such as schools and hospitals, which are located within the smallest slum of Iwaya. This would be carried out concurrently with fabricating the Tiny Abod homes, which would be quick to construct and would be used temporarily until the funding and resources for more durable homes were to become available. Following the 5-year period, and depending upon the success of the initial phase of the program, Lagos could begin replacing the Tiny Abod homes with these resilient structures within Iwaya, and begin creating new schools, hospital and community buildings within other slightly larger slums. The initial construction should be done following Build Change's wood construction practices.

\subsubsection{Mobile Community Micro-financing Services}

A major factor contributing to poverty within the city of Lagos is the lack of financial services offered to the poor. This also plays a role in property ownership and maintenance, due to the inability of this entire sector of the population to acquire loans. Many low-income Lagos residents do not have the ability to save money because they are not supported by a bank, and, therefore, handle most of their transactions with cash, which often creates a situation that is conducive to increased spending. By establishing financial services through Community Micro-financing Institutions, people with limited financial resources will have the opportunity to take out small loans, create savings accounts and utilize mobile transfer and payment services, allowing for the creation of a more stable financial system within the slums.

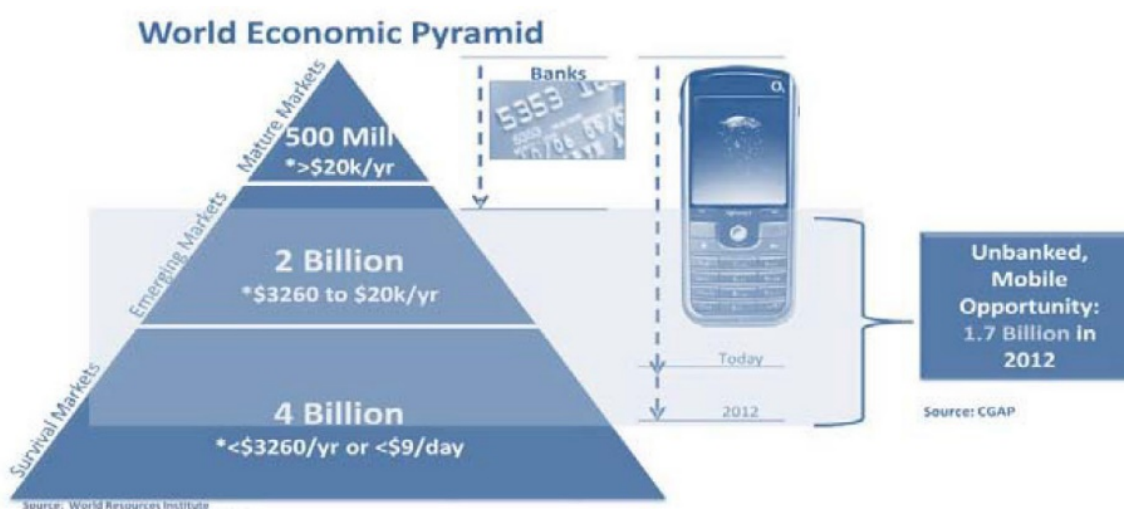

Exhibit 2. World Economic Pyramid

Source: Grameen Foundation Best Practices in Mobile Microfinance, 2013. 
In Exhibit 2, the Grameen Foundation graphically represents the distribution of the world's economic markets, and indicates its untouched population. Many of Lagos' inhabitants fall into the 1.7 billion people at the far right of the graphic who do not currently belong to a bank and could potentially be brought into the pyramid through mobile financial services.

Successful examples of micro-finance implementation can be found at this foundation, which was founded in Bangladesh. It is a non-profit organization that works on projects related to improving the lives of the world's poorest populations through financial services and education. The foundation places an emphasis on mobile services due to the widespread use of cellular phones within the developing world. The lack of financing and infrastructure for land lines makes it essential for people living in the slums of Lagos to own and use cell phones; therefore, making banking services accessible through mobile devices would be the best way to improve the financial situation of the people.

Another focus area of the Grameen Foundation is savings. It works with existing micro-finance institutions, commercial banks and telecommunication providers to develop a framework and set of tools to promote increased savings by the poor. These savings programs should be safe, reliable and convenient to the population, and information should be provided on how to use them. They empower the people by giving them the opportunity to save for the future and make their own decisions about personal financial needs (Grameen Foundation, 2013).

The best example of the Grameen Foundation's work in combining both savings and mobile services can be seen in their partnership with the micro- finance institution, Cashpor, located in Varanasi, India. The 2 organizations combined efforts to provide financial services to low-income women, allowing them to open savings accounts for the equivalent of US \$100. Transactions could be conducted via mobile device, since the Indian government did not allow micro-financing institutions to handle them on the ground within the country. Each transaction would cost the user $\$ 0.03$, or they were given the option to pay a yearly fee of $\$ 0.84$ for unlimited transactions. By adding a cost for transactions, the bank wished to reduce the interaction of the people and their money, allowing them to save more. The deposit to withdrawal ratio for the savings services in the pilot program was 9:1, which demonstrated how the accounts were being properly utilized and achieving the results that the foundation had intended (Ibid.).

It is recommended that Lagos follow the example that is provided by the Grameen Foundation's work with Cashpor. This would not require the establishment of brick-and-mortar financial institutions, but would instead create a mobile banking system. Thus, the city would not have to invest much money in infrastructure and construction, and would instead be able to channel these funds into further loans.

Lagos' mobile financial services could be managed by the well-established and successful NGO, the Cooperative for Assistance and Relief Everywhere (CARE). It currently works in a variety of developing countries on projects that are most often connected to empowering women. The focus on getting women involved in micro-finance programs is due to 1) the fact that women are underserved in the financial market and rarely have bank accounts of their 
own, and 2) the fact that women are considered more reliable when it comes to paying back loans and managing their savings. In many developing countries, the women are often the ones who informally manage the family's finances, controlling how much money is spent by the members of the family, based on need. One related example of CARE's work can be seen in Kenya, where the organization has helped connect the poor with micro-finance institutions, and helped them save over $\$ 120,000$. CARE's main goal is to encourage the use of self-sustaining business models within poor communities, and to link the currently existing informal financial systems within these communities to newer, safer formal systems (CARE, 2012).

The initial phase of Lagos' mobile micro-financing services would require an educational campaign. Because most of the city's poor population has never had access to formal financial institutions, it is essential that CARE staff work with communities to increase awareness about the services that will be provided, how to access them through the use of mobile devices, and their options when it comes to saving and borrowing money. If the program is to work effectively at increasing saving capacity and creating a sense of ownership over accounts and property, the people must fully understand what they are entering into and the benefits they can receive.

Once an initial awareness campaign is established, CARE and Grameen staff may begin the process of starting accounts for those who wish to become involved. These participants must have access to cellular devices in order to conduct financial transactions. Due to the cost of owning a landline and the installation of necessary infrastructure, most of the population of Nigeria utilizes only cellular devices, making these banking services possible. Those who open accounts will be able to make deposits and check balances via mobile devices. Kiosks should be created within slum communities that will allow for withdrawals and deposits from these mobile accounts.

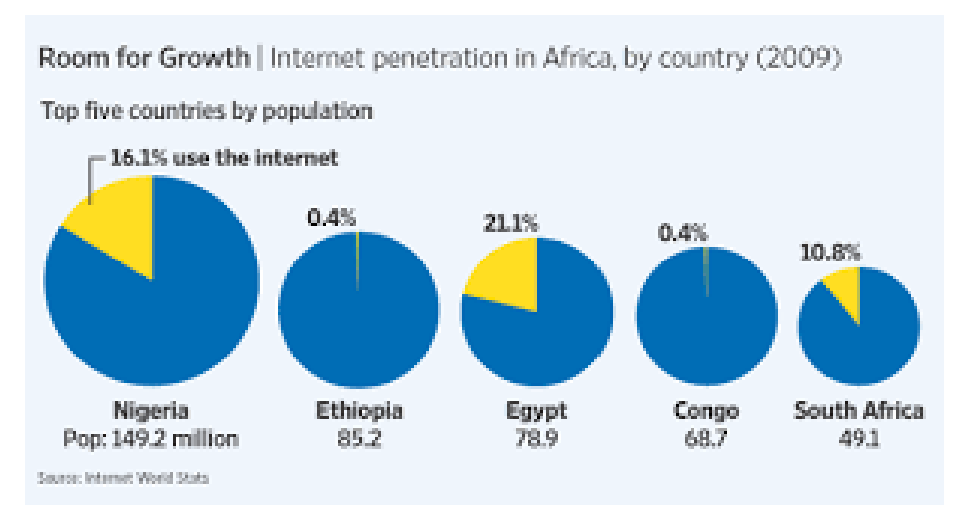

Exhibit 3. Internet Usage in African Countries, 2009

Source: Wall Street Journal Online, 2010.

By providing a formal financial system for the underserved poor population within Lagos, the city will experience an increased sense of responsibility for the preservation and upkeep of 


\section{Macrothink}

the often neglected slum areas. Giving the people an option to save their money, build credit and take out loans will increase their involvement in the local economic market, which will benefit the city as a whole, as well as possibly pull some out of poverty. Increased investment in slums may positively affect property values, thereby benefiting the community and the individual.

\subsection{Project Financing and Implementation}

\begin{tabular}{llllll}
\hline Program & Year 1 & Year 2 & Year 3 & Year 4 & Year 5 \\
\hline $\begin{array}{l}\text { Land } \\
\text { Titling }\end{array}$ & $2,000,000$ & 750,000 & 750,000 & 750,000 & 750,000 \\
$\begin{array}{l}\text { Abod } \\
\text { Homes }\end{array}$ & $20,000,000$ & $20,000,000$ & $20,000,000$ & $20,000,000$ & $15,000,000$ \\
$\begin{array}{l}\text { Build } \\
\text { Change } \\
\text { Mobile }\end{array}$ & $1,000,000$ & 250,000 & 250,000 & 250,000 & 250,000 \\
Finance & $3,000,000$ & $2,000,000$ & $1,000,000$ & $1,000,000$ & $1,000,000$ \\
\hline
\end{tabular}

\section{Exhibit 4. 5 Year Financing of Programs (in US Dollars)}

Source: Chapter authors.

For the initial 5-year period of all of the aforementioned programs, financing has been broken down into yearly increments, displayed in Exhibit 4 above. Because of the land-titling program's emphasis on policy and the involvement of government departments, this program will need to be funded primarily through public sources. Exhibit 5 below shows the breakdown of initial investments made in the LAMP2 project. The city should contribute 3 million dollars for foundational investments, and the World Bank should be willing to provide money to cover the remaining costs of the program.

\begin{tabular}{|l|l|}
\hline Initial Commitment & Amount in US Dollars \\
\hline Borrower & 3 Mil \\
\hline World Bank & 20 Mil \\
\hline
\end{tabular}

Exhibit 5. Land Titling Program Financing

Source: Chapter authors.

As seen in Exhibit 4, the Build Change Program requires the least investment of the 4 
projects being recommended. However, the initial costs are significantly higher than those of the following 4 years due to project start-up. This will cover building materials and labor costs for Build Change employees. Due to the educational component of the program, the residents of the slums of Lagos will be able to construct buildings on their own accord, allowing a large reduction in the need for funds for the program after the initial phase.

\begin{tabular}{|l|l|} 
Costs & Amount in US Dollars \\
\hline Contributions/Grants & $15 \mathrm{Mil}$ \\
\hline Program Revenues & $2 \mathrm{Mil}$ \\
\hline Initial Microfinance Expenses & $4 \mathrm{Mil}$ \\
\hline
\end{tabular}

Exhibit 6. Micro-finance Financial Breakdown

Source: Chapter authors.

Exhibit 6 shows the breakdown of initial finance required for the Mobile Micro-financing Program and the revenue to be brought in by the program itself. One organization that invests significant money for the creation of financial programs in developing countries is the Bill and Melinda Gates Foundation. The foundation has a specific interest in programs that utilize technological innovation, particularly mobile services. With the financial support of the Gates Foundation, public funding would not be necessary, and the city could use the money saved for other, smaller projects.

\section{Industry}

\subsection{Context: Nigerian Industry}

\subsubsection{Existing Economic Conditions}

Today, Lagos' main central business district is located on Lagos Island's southwestern shore. The area is known as Lagos' epicenter for commerce, finance, administration, and education (Encyclopedia Britannica, 2014). The primary industries in the city include automobile and radio assembly, food and beverage processing, metalwork, and the production of paints and soaps. Other industries that play an important role in the Lagos economy include textiles, cosmetics and pharmaceutical manufacturing. The fishing industry is also an important component of the Lagos economy (Ibid.). Apapa Quay, Lagos' most important port and primary outlet for Nigerian exports, is located on the mainland.

After years of limited growth and political corruption and ineptitude, Nigeria is poised to become a mjor force in the international economy as investors from Asia, India, Europe and the Americas begin to increase their efforts in Africa. Nigeria, Africa's largest economy, is 
dominated by crude oil and petroleum abstracted from the Niger Delta's sedimentary basin, making it one of the world's most renowned and profitable oil provinces. A member of the Organization of Petroleum Exporting Countries (OPEC) since 1971, Nigeria is responsible for approximately 6\% of OPEC's annual oil production (Nigeria Economic Report, 2014), and it relies on a high oil price. Crude oil is its biggest source of income, accounting for about $75 \%$ or $\$ 50$ billion, of the Nigerian government's total annual revenue, according to a report by analysts at Deutsche Bank (Hjelmgaard, 2014). However, despite having a strong petroleum footprint, Nigeria still imports more than $80 \%$ of its refined petroleum products to service the country because of insufficient domestic refining capacity (Business Day, 2014).

There is no question petroleum and oil is a very lucrative industry in Nigeria with plenty of potential and improvement still possible. However, there has been a growing concern in recent years with regards to Nigeria's economic dependence on the oil sector over the last 3 decades. If Nigeria intends to create a sustainable and progressive economy, it must diversify its economic portfolio and begin to promote and invest in different industries such as agriculture, manufacturing, technology and entrepreneurship. Just recently, the Minister of Finance, Ngozi Okonjo-Iweala, stated that Nigeria is "too dependent on oil and we must help businesses set up in other sectors, such as manufacturing and agriculture (Premium Times, 2014)." In recent years, Nigeria has invested more in the agriculture, service and trade industries, but it must continue to improve on this momentum. A key reason for these philosophical changes regarding the economy are the strategies developed in the 2020 Vision and the Transformation Agenda. A goal of these initiatives is to improve competiveness and productivity in order to contend with China and India on a global scale. One component of the Transformation Agenda includes policies designed to promote economic diversification via increased power supply and enhancing the value-chain of agricultural manufacturing. In particular, an analysis of the existing tariff and non-tariff structure concerning increasing import protection for a variety of agricultural products is being conducted (International Monetary Fund Report for Nigeria, 2014).

\subsubsection{Economic Outlook}

Despite the effects of the global recession from 2008-2012, Nigeria seems to be showing slight signs of economic improvement as real GDP grew 6.8\% in Q3 of 2013. However, GDP growth for 2011, 2012 and 2013 was 5.3\%, 4.2\%, and 5.5\% respectively (Nigeria Economic Report, 2014). This was largely the result of growth in the non-oil sector industries that consisted primarily of agriculture, services, and trade (International Monetary Fund, 2014). However, oil production, despite slight improvement, remained below capacity as a result of continued losses from theft and damage and has brought down the overall GDP growth over the last 3 years. Inflation continued to decline in 2013 as food and utility prices trended lower. However, principal inflation rose from May 2013 until the end of 2013 because of increased prices for imports (Ibid.). Moreover, with the rapid fall in oil prices in the second half of 2014 and early 2015 from over \$100/barrel, Nigeria’s revenues from crude oil have declined, and any long-term price stabilization at the mid-January 2015 level (c. \$50/barrel) would be very damaging to the economy. 
In contrast, the plastics and rubber industry posted annual growth rates over $30 \%$ from 2011-2013. This industry has been an important source of exports other than oil and gas (Nigerian Economic Report, 2014). However, the trade and transportation industries have experienced erratic behavior over the last 3 years. The trade industry has been affected by higher transportation costs and challenges in 2012 that consisted of a national strike, severe flooding through many regions and increased security challenges. The erratic GDP growth in agriculture is believed to be correlated to the slow progress in poverty reduction throughout Nigeria (Ibid.). Nevertheless, growth was expected to increase from $6.4 \%$ in 2013 to $7.3 \%$ in 2014, under the assumption that oil production and agriculture would improve under new reforms.

\subsection{Proposed Projects}

\subsubsection{Pharmaceuticals}

Project 1: Develop and promote conventional medicine products by increasing medical knowledge through research.

The plan is to educate the community on complementary and alternative medicine (CAM) and to develop and promote conventional medicine products. Physicians should initiate discussions on the use of CAM during clinic visits or phone calls. This will aid parents/patients to make correct decisions about using CAM. Clinical trials on CAM products should be done to ensure these remedies are safe.

The use of CAM is increasing globally. Nigeria is one of those countries that uses CAM for chronic illnesses due to poverty and lack of knowledge. $80 \%$ of the population in developing countries is dependent upon traditional healing methods (World Health Organization, 2002). It is known that herbal medicines are the first line of treatment for $60 \%$ of children with high fever in Nigeria (World Health Organization, 2003). Only 20\% of all herbal medicines are registered with the National Agency for Food and Drug Control. Within this 20\%, most of the medicines are imported. The other $80 \%$ are available for purchase in open markets. The danger of this is that misleading information could be given and put a life at risk (Obi et al., 2006). According to Oshikoya et al. (2008), the average cost per month of using CAM every day is $\$ 70.10$. The side effects of using CAM are unknown, as are those for using CAM and conventional medicines at the same time. Thus, being able to research or educate could save lives. Most of the facilities in Lagos are old and need to be modernized. Laboratory equipment needs to be updated for this research to take place due to the fact that the pharmaceutical industry is always changing.

Developing and getting a new drug to the market costs, on average, \$350 million. This cost is covered mostly by grants or deals with large pharmaceutical partners. Another way for smaller companies is by adopting drugs that were abandoned by other companies (Desmond-Hellman, 2013). Developing a new drug will have to take place in a research environment. An example for the cost of a new pharmaceutical facility is the one being built in Algeria for \$32 million (Pharmaceutical Business Review, 2012). To acquire these buildings and have up to date equipment, the Nigerian government will be required to help. 


\subsubsection{Petrochemicals}

Project 2: Attract petrochemical refineries to the new industrial estates.

There is a need to develop new petrochemical refineries in Nigeria. Petrochemicals are found in a lot of items. These include medicines, cosmetics, gas and oil products, etc. Nigeria is one of the leading countries importing most of these items. For example, Nigeria obtains most of its conventional medicines from India, the US, Germany, etc. (Chiejina, 2014). Given this situation, if Nigeria developed its own petrochemical refineries, the country would start to develop more of its own industries and put their revenues back into Nigeria. This is the rationale for the new Dakote petrochemical chemical plant in the Lekki Free Trade Zone mentioned previously. According to Ugbodaga, only 35\% of its products will be kept in Nigeria while the rest will be exported. The refinery will be a major selling point for further development in this zone, and it has the potential to have an impact for the better on the Nigerian economy (Ugbodaga, 2014).

Developing this petrochemical refinery will cost $\$ 700$ million, but Alhaji Aliko Dangote is investing over N1.5 trillion ( $\$ 9$ billion) to establish the Lekki Free Trade Zone. The project is already beginning to take shape. Other individuals are starting to help build the zone by constructing tank farms and other refineries. Lagos Governor Babtunde Fashola is also involved in financing the Lekki Free Trade Zone (Ibid.).

\subsubsection{Agriculture}

Project 3: Continue Lagos' momentum in the agriculture sector by attracting Unilever to develop a palm oil processing plant.

The agriculture industry is seen as one of the largest growth sectors in Nigeria. The country has several crops that have significant export potential, including rice, cassava, sorghum, palm oil, cocoa and cotton (Nigeria International Monetary Fund, 2014). Therefore, the development of a processing plant to the west of Apapa would also provide 2,000 acres of land for palm oil cultivation and be a convenient location for transporting the palm oil to Lagos port.

The construction of a large palm oil manufacturing plant is essential in order to stimulate Lagos' economy via the creation of thousands of jobs and substantial export revenue. Unilever is a major international player in the processing of palm oil across the globe, and the company currently has several palm oil processing plants in Indonesia and Malaysia. Unilever has made great strides to improve its extraction of palm oil in an eco-friendly manner. This has set the firm apart from other companies and illustrates its commitment to the environment. Unilever made a pledge to source $100 \%$ of the palm oil it uses by 2015 . The company accomplished this goal with its first fully traceable sustainable palm oil plant in 2013 when it broke ground on its Indonesian plant (Unilever Press Release, 2013).

The implementation and development of a plant in Lagos will also attract other companies and lead to more opportunities for job creation throughout Lagos and the rest of Nigeria for palm oil and other processing plants. In addition to providing economic benefits, the 
processing of palm oil will have an impact on human rights by providing inputs to the local manufacture of such products as soap, detergent, shampoo, lotion and more.

The majority of the funding to develop a palm oil manufacturing plant would be provided through private investment. A company such as Unilever is the most desirable option because of its financial capabilities and expertise on a global scale, and Lagos is a logical location for expansion into Africa. The total cost of the project, including land acquisition for the plantation area and construction of the facility, is estimated to be $\$ 130$ million. Lagos may choose to offset a portion of the total cost through tax breaks or incentives in order to ensure Unilever's investment (Suzuki, 2014).

\subsubsection{Job Training and Education}

Project 4: Increase labor production and entrepreneurship through the expansion of job training and skill-learning programs.

These programs in Lagos include teaching skills in farming, carpentry, concrete, etc. and providing capital for the infrastructure and materials necessary for these programs (e.g., farmland, wood, tools and a shop for carpenters). The job training and trade skills that are developed from these expanded programs will allow the people of Lagos to improve their financial and social capabilities because they will be more qualified for job opportunities. Furthermore, increased investment in trade programs for youth will keep them from crime and social temptation. Enabling them to learn skills at an early age may help some to one day open their own businesses.

Recently, a strong program called “Agric-YES,” was started to increase entrepreneurship and develop trade skills in Lagos' youth. The goal of the plan suggested here is to use this program as a starting point to develop more programs of a similar nature. Originating in 2009, Agric-YES aims to develop new generations of agro-entrepreneurs in poultry, fish farming, bee-keeping and vegetable farming by targeting Nigeria's youth (Eteghe, 2014). The students who enter this program go through 6 months of rigorous training and spend time at an internship before they are left on their own (Ibid.). After the training and internship period, each student is given start-up money to carry out his or her business venture. This funding is provided by the government and includes both cash and plots of land to assist the students (Ibid.). The plan suggested here would be designed to not only teach students about different trades, but also place a strong emphasis on practical business skills. The selection process would include an application and interview process, but also target specific areas where economic prosperity is struggling. The program developed by this plan will also include monthly checkups to ensure that the participants' businesses are performing well and running smoothly or if there is any further need for assistance.

Job training and entrepreneurship programs are essential in order for Lagos to further expand into different industries. Lagos must invest in rigorous job training and entrepreneurship programs that will enable its citizens to obtain the new jobs that are created in the country. Lagos should also invest in further developing apprenticeships and internships for its youth so that it can build a solid foundation of trade and service industries. The only way startups 
will be able to succeed is if Nigeria invests the capital to help these entrepreneurs learn and develop the skills that are required to run a sustainable business. Developing a rigorous job training platform will help improve existing company production and make the transition for new companies relocating to Lagos much easier. For example, implementing a strict job training platform before construction of the proposed palm oil processing plant is complete will make the employee hiring and selection process more competitive and operations more efficient once it opens. As more citizens learn and develop skills, they will have opportunities to start their own businesses, hire more employees and thus further improve the overall economy in Lagos.

The estimated costs to fund training and entrepreneurship programs are very hard to calculate. However, there are funding sources available to help mitigate the startup costs for these programs. For example, the Agricultural Transformation Agenda (ATA) was launched in 2012 to help Nigeria become a global power in agriculture. This campaign has set aside millions of dollars for investment in agriculture and manufacturing facilities. Another potential source of funding is the Bill and Melinda Gates Foundation, which has a track record for donating millions of dollars for agricultural development in Africa.

\subsubsection{Automobiles}

Project 5: Attract Toyota and train locals to use its manufacturing equipment.

Nigeria is a major and growing automotive market in Africa. If Nigeria would open a manufacturing company, it would allow revenues to be kept in the country and allow Nigeria to industrialize further. Opening and operating an automobile assembly plant would create thousands of new jobs. According to Business Day, "It is expected that when fully operational the new vehicle manufacturing industry will create 70,000 skilled and semi-skilled jobs along with 210,000 indirect jobs in small and medium sized enterprises (SMEs) that will supply the assembly plants (Business Day, 2014)." This would decrease the amount of poverty in Nigeria and also allow more families to have an automobile for travel. Opening a factory has other benefits as well. As stated by Vanguard, "It would save them the trouble of going abroad to seal such business deals and most importantly it will bring these foreign companies into the country, resulting in increased activities in the sector, more production and increased products lines and quality, which will in both the short and long runs rub off positively on the sector (Vanguard, 2014).” Automobiles could then start to be made in Nigeria and exported. Toyota should be the first assembly plant to open. A recent article published in Nigeria stated that, "50 percent of the vehicles on the road in Nigeria are made by the world's biggest automobile company Toyota (ThisDayLive, 2014).” It is known that Nigeria spent \$3,451 billion on 400,000 imported vehicles in 2012. It seems that Toyota would benefit greatly in the African automotive market by entering Nigeria.

The capital cost for Toyota to establish an assembly line in in Lagos will be about $\$ 1.7$ billion, which would be largely self-financed. 


\subsection{Timing}

2015:

- Establish research on CAM; develop and test three alternative medicines from the list and educate the public on conventional versus alternatives medicines;

- The first 6 months would be used to conduct research on which petrochemical facilities would thrive in Lagos and Nigeria; then a plan would be implemented to construct the facilities, and upfront costs would be applied to start construction;

- Negotiate with the Lagos government and/or local farmers regarding land ownership, and

- Secure funding for training and entrepreneurship programs.

2016:

- Continue testing the 3 alternative medicines;

- Continue building the petrochemical facilities;

- Acquire 5,000 acres of land for a palm oil tree plantation and the construction of a sustainable/LEED certified processing facility; begin initial planning and permitting;

- Acquire land for farming and manufacturing training and entrepreneurial programs; begin land procurement and construction of structures to be used for the programs, and

- Get Toyota to recalculate their statistics on the African automobile industry.

2017:

- Continue testing the 3 alternative medicines;

- Wrap up the construction of the first petrochemical facilities;

- Begin the first phase of land preparation for the palm oil tree plantation and break ground for the first phase of the construction of the processing facility, and

- Create a filtering and selection process for individuals to participate in entrepreneurship and training programs; admit individuals into these programs.

2018:

- Continue testing the 3 alternative medicines;

- Start refining at the petrochemical facilities, and

- Finish interior construction features of the palm oil processing facility including chemical, mechanical, lighting and HVAC systems. 
2019:

- Continue testing the 3 alternative medicines, and

- Relocate, move and/or hire management personnel for the new facilities; begin the search/hiring process for employees from the local population.

\section{Sewage and Solid Waste}

\subsection{Background}

A combination of neglect, political corruption and rapid population growth, along with uncontrolled urban sprawl, has led to the decay of the existing sanitary infrastructure within Lagos State (World Bank, 2006). The Lagos government has constructed sewage treatment plants in some housing estates, but due to the electricity demand of the waste treatment equipment and the spotty availability of electrical power in the region, most of these treatment plants are non-functioning (Iwuga et al., 2003). Existing infrastructure in the region suffers from poor planning, where it is common that drinking water piping passes through open drainage pits containing human waste.

The vast majority of inner-city residents rely on sanitation practices such as open defecation, defecation in plastic bags, various types of latrine, pour-flush toilets discharging to open drains and pour-flush toilets discharging to septic tanks. The Sewage and Water Department of the State Ministry has yet to devise an efficient system to deal with septage from septic tanks or sewage spillways (Ibid.). Canals have been constructed to aid in the transport of human waste water out of slum areas, mainly draining into lagoons or other water bodies surrounding the city. Trash that has been improperly discarded commonly clogs these systems, and with no formal maintenance in place, many of these drainage canals are clogged with refuse, rendering them non-functional. Without access to hygienic toilets or human waste collection/sanitation systems in place, people are forced to discharge fecal waste directly to the environment; without adequate treatment, these practices have detrimental impacts on the disease burden and the quality of life of resident populations (Hutton et al., 2007).

Similarly, 10,000 tons of waste per day are generated in Lagos (De Comarmond, 2014), but a sufficient and successful solid waste collection service has yet to be implemented throughout the low-income communities. This lack of an operational infrastructure yields a myriad of problems for the majority of the city's population, the most significant being critical environmental and health issues.

While the city does, in fact, have a state-funded waste collection service provided by the Lagos State Management Authority (LAWMA), a significant lack of current resources and funding means that only about $40 \%$ to $50 \%$ of the city's waste is being collected (Ojo \& Bowen, 2014). This, in combination with various other factors, including poor public awareness and education, lack of incentives for participation and fear of government manipulation, has led to an overwhelming amount of solid waste littered throughout the city.

To date, no effective solid waste collection or treatment plans have been implemented in Lagos. Scholars and politicians alike have attempted to remedy the problem, but due to 
budget and resource restrictions, most plans have gone unexecuted or have been unsuccessful. Moreover, due to the incessant nature of the issue, the longer it remains unaddressed and unsolved, the worse the conditions will become, causing further damage to the environment and greater obstruction to future treatment. Thus, in regard to an effective development plan, a comprehensive approach needs to be taken. It is vital to consider not only the functionality of the strategy, but also to address the feasibility, including the fundamental issue of public acceptance and engagement.

\subsection{Selected Projects}

\subsubsection{Selected Projects for the Sewage Sector}

The following projects, focused on the Iwaya slum, are deemed a priority for implementation to supply sanitation needs of Lagos inner-city slum populations.

Project 1: This project is aimed at reducing current disposal practices of human waste (open defecation and littering) by providing facilities that can collect and dispose of this waste in a clean and sustainable manner.

In order to serve the dense inner city populations of Lagos and to alleviate current human waste disposal practices (open defecation), the construction of communal toilet facilities is recommended. Research conducted in Nairobi, Kenya concluded that communal sanitation facilities are a viable and appropriate alternative for sanitation in slum areas (Schouten \& Mathenge, 2010). For rapidly growing cities such as Lagos, proper sanitation is critical for the societal and economic advancement of the population.

Communal sanitation facilities have the ability to serve large populations. Depending on design complexity, communal sanitation facilities can be built in a cost-effective and environmentally friendly manner. Materials for construction constitute the largest expense; however, this can be avoided by sourcing local materials. Currently, thick layers of discarded rubbish cover the ground in Lagos slum areas, blocking the existing sewage drainage ditches and impeding the access of transportation within those areas. It is recommended that discarded trash be collected and compressed for use as building blocks for the communal sanitation facilities (Kriscenski, 2007) as well as residential housing.

To make these facilities energy efficient, it is suggested that several "green" technologies be employed. Roof rain-catchment devices can supply sufficient water for toilet flushing, showers and laundry stations within the facility. Sanitation systems such as pour-flush toilets are recommended since they use only the necessary amount of water per flush, in turn creating less wastewater requiring treatment. The sun's energy can be harvested to light and heat the facility as well. Lighting can be supplied by using low-grade recycled glass for ceiling tiles to allow for natural lighting within the sanitation facility. Hot water can be provided by simply using heat absorbent black plastic rain-water collection containers.

Various designs of communal sanitation facilities exist and are dependent on the geographical location of their installation. For Lagos, indigenous African urban forms must be considered in designing these facilities to ensure community acceptance and use of the facilities 
(Asomani-Boateng, 2011). Traditional designs will allow for facilities that will not only be visually appealing, but will also serve the function of promoting proper sanitation to the residents of Lagos slums. If planned appropriately, these facilities can double as communal gathering sites and educational centers in hopes of strengthen community ties while promoting land stewardship through education.

Project 2: Proper sewage treatment is a necessity for dense inner-city populations in Lagos. Using low cost, low maintenance wastewater treatment systems such as wetlands, human waste can be properly treated and disinfected prior to release into environmental water bodies.

Constructed wetland treatment systems are engineered systems designed and constructed to utilize natural processes to assist in treating wastewater (USEPA, 2000). Many studies have provided evidence that wetlands can be an efficient environmentally friendly option for wastewater treatment (Adeniran et al., 2014; Kopec, 2007). For more than 2 decades, wetland wastewater treatment systems have been successfully implemented in other developing countries (Zhang et al., 2012). Researchers have demonstrated that wetlands have the ability to treat wastewater to levels comparable to that of traditional wastewater treatment plants and have been recommended for use in Lagos (Adeniran et al., 2014; Zhang et al., 2012). Constructed wetlands are a cost-effective, low maintenance approach to wastewater treatment compared to expensive and maintenance intensive wastewater treatment plants, while having the flexibility to handle varying wastewater fluctuations. Aside from wastewater treatment, wetlands have the capability of treating agricultural wastes, industrial waste and urban drainage (Hammer, 1989).

Project 3: Educate inner-city Lagos residents about the importance and benefits of proper sanitation. Through education, it is hoped that community members will utilize communal sanitation facilities to dispose of human wastes properly.

Project 4: Institute a management system to ensure that sanitation facilities are clean and operational to promote their use. Maintenance will be financed through the collection of small usage fees. Usage fees will be used to fund cleaning attendants as well as a maintenance crew that is capable of performing repairs as needed.

\subsubsection{Selected Projects for the Solid Waste Sector}

Project 1: Reduce generation of waste with the establishment and implementation of best practices for individual solid waste management through awareness and education campaigns.

An essential component of developing successful solid waste management is overcoming the barriers of public disapproval and rejection. In regard to a lack of participation on behalf of Lagos citizens, various explanations have been identified. It is apparent that a significant restriction is the lack of existing or effective recycling education, with a considerable $40 \%$ of the results related to lack of awareness or education. Additionally, 20\% of interviewed individuals shared that they had "no interest" in recycling practices. Together, these factors create constraints that need to be addressed before any successful development plan can be 


\section{Macrothink}

International Journal of Social Science Research

ISSN 2327-5510

2015, Vol. 3, No. 1

enacted (Otitoju, 2014). Therefore, it is proposed that solid waste management best practices be established through ongoing awareness campaigns that include an applicable educational aspect. Campaign events are to be held at the expected communal sanitation facilities, with a specific emphasis on healthy sanitation practices and the myriad benefits such practices yield.

Project 2: Expand local recycling collection services.

An effective waste collection service is a necessity for any solid waste management plan. Wecyclers, a small, Lagos-based enterprise that began in 2012, serves as the ideological foundation for the expansion of recycling programs and services throughout the city. The company utilizes cargo bicycles to maneuver the littered streets of the city and to collect recyclable material from households. Lagos' citizens are incentivized to participate in the program, as Wecyclers offers redeemable points for various weights of recycled material. The program is partially funded by the Lagos State Government, which enables the public's mistrust of the government to be effectively addressed. Through the Wecyclers initiative, individuals are educated on the best practices of solid waste management, encouraged to participate in recycling programs, and engaged in improving their own communities.

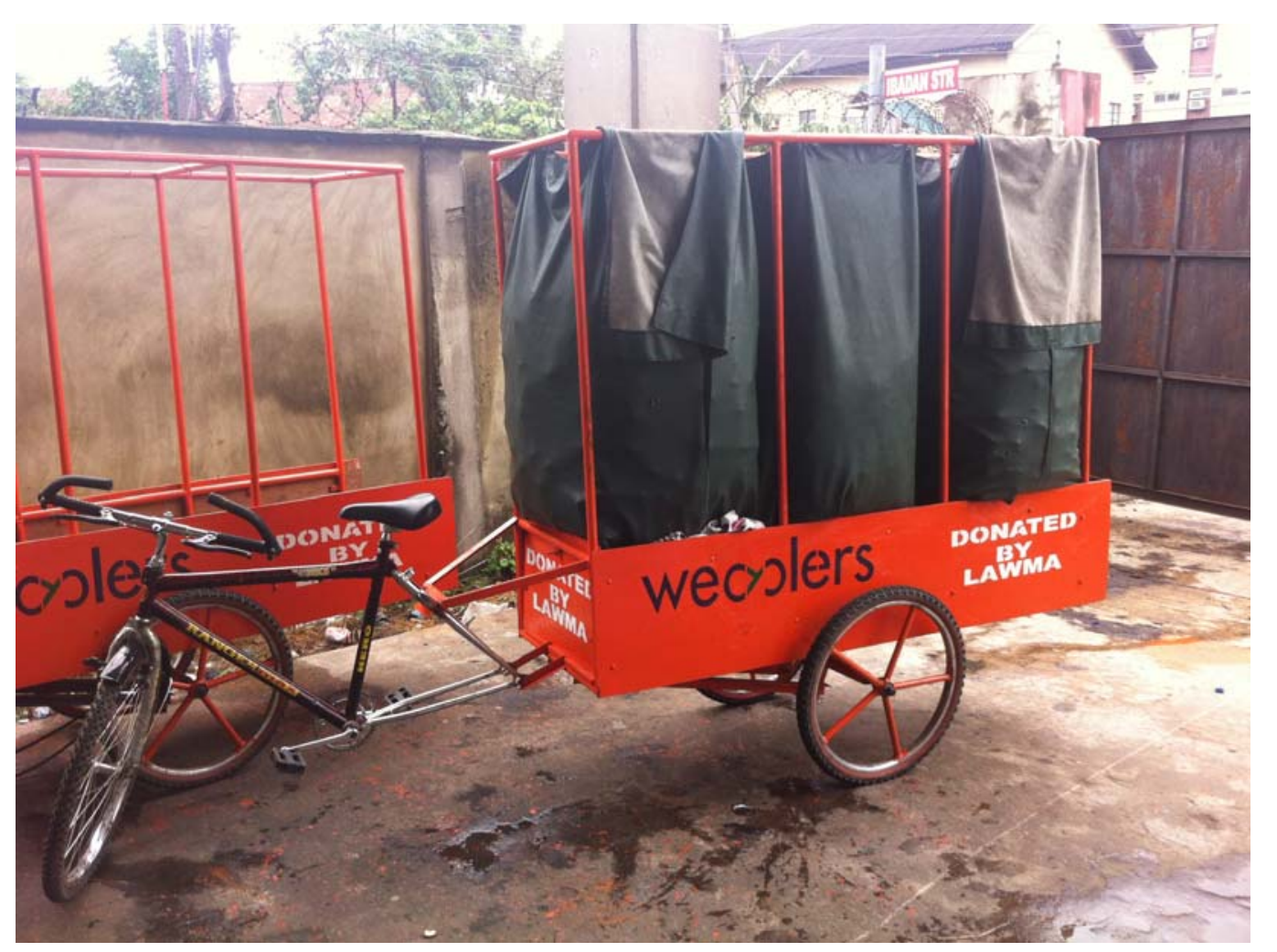

Exhibit 7. Wecycle Cargo Bicycle

Source: Co-Creation Hub Nigeria, 2014.

Currently, the Wecyclers program has 30 operational cargo bikes, with which it services 5000 households throughout Lagos (Kermeliotis and Ellis, 2014). An expansion of the service across all of Lagos is the end goal; however, the focus of the initial 5-year plan is the Iwaya 
community. To expand the Wecyclers recycling collection service to address the needs of this community, a total of 18 new cargo bicycles are required. These additional resources will enable the collection of recyclable goods from the entire Iwaya population of 15,100 . When collected, these goods will be temporarily stored at the constructed communal sanitation centers until they can be distributed to regional facilities.

Project 3: Create decentralized solid waste collection, storage and sorting centers.

To supplement the expansion of local collection services, the accessibility of waste storage and sorting centers will need to be increased. Through partnerships with the Lagos State Government, facilities will be established regionally. Current non-operational landfill sites of the Lagos State Waste Management Authority (LAWMA), including those in Isolo, Olusosun, and Abule-Egba, are to be converted into the necessary facilities. Over the first 5 years of development, the aim is to complete the conversion of the former Olusosun landfill site. This resource will be the main collection, storage and sorting facility for the recyclable material collected throughout the Iwaya community.

To transport the recyclable material from Iwaya to the Olusosun facility, LAWMA "dinasseur" trucks will be used. Based on the population of Iwaya, it has been determined that two dinasseur trucks will be needed and will operate bi-weekly to transfer the material. Once the material arrives at the regional facility, it will be sorted and either reserved to be upcycled or sold to recycling processors. The profit made from such transactions will be used to cover operational costs of the program.

Project 4: Utilize existing solid waste to construct localized communal sanitation facilities.

The construction of localized communal sanitation facilities in Lagos is currently a large expense of the sewage and solid waste development sector. To alleviate this budget constraint, useable waste materials will be collected and rehabilitated into practical resources for the production of the facilities.

Project 5: Establish a hierarchy of implementation through regional actors and NGOs.

A key component of successful solid waste management is public acceptance and contribution. To address this vital element, it is recommended that a hierarchy of implementation be established. Such a structure would include pre-established actors, including the regional nongovernmental organization, the Social and Economic Rights Action Center (SERAC) of Lagos, who currently run a "Right to City" campaign where it works with local leaders to raise awareness and facilitate education of significant issues (Projects, 2014). Additionally, the model would include the Lagos Marginalized Community Forum (LAMCOFOR), which is a local actor, composed of Lagos community representatives who act as the middlemen between organizations like SERAC and the general population. When operational, recycling initiatives and campaigns would initially be proposed to SERAC, and, if accepted, SERAC would then introduce the ideas to the representatives of LAMCOFOR, who would encourage individual communities, such as Iwaya, to contribute to the initiatives.

This approach to implementation overcomes many barriers to public participation in 
recycling ventures, and is effective in facilitating educational and awareness campaigns. Moreover, it allows the initiatives to be driven by the community, not forced by the Lagos State Government. Combined, these factors will yield greater public support and participation, thus enhancing the impact of solid waste management development.

\subsection{Capital Costs}

\subsubsection{Capital Costs for Sewage Projects}

Exhibit 8 below outlines the total cost estimates for the construction of sanitation facilities and wetland areas. Sanitation project implementation will focus on the Iwaya slum from mid-2015 to 2020. Total capital costs required for construction will total $\$ 535,000$. For the 10 remaining Lagos inner-city slums sanitation implementation will cost $\$ 84,465,000$; these projects will span 2020 to 2025.

\begin{tabular}{|c|c|c|c|c|c|c|c|}
\hline Slum & Population & $\begin{array}{l}\text { Toilet } \\
\text { Facilities }^{1} \text { Required }^{1}\end{array}$ & $\begin{array}{l}\text { Sewage } \\
\text { Produced } \\
\text { Gal./Day }^{2}\end{array}$ & $\begin{array}{l}\text { Land } \\
\text { Req. } \\
\text { (Acre) }^{3}\end{array}$ & $\begin{array}{l}\text { Land } \\
\text { Price } \\
\text { (\$US) }\end{array}$ & $\begin{array}{l}\text { Construct } \\
\text { Sanitation } \\
\text { Facilities } \\
(\$ \mathrm{US})^{4}\end{array}$ & $\begin{array}{l}\text { Wetland } \\
\text { Const. } \\
(\$ \mathrm{US})^{5}\end{array}$ \\
\hline Mushin & 633,120 & 264 & 835,718 & 8.4 & $20 \mathrm{M}$ & $12 \mathrm{M}$ & $613 \mathrm{~K}$ \\
\hline Agege & 459,939 & 192 & 607,119 & 6.1 & $4 \mathrm{M}$ & $9 \mathrm{M}$ & $445 \mathrm{~K}$ \\
\hline Shomolu & 402,673 & 168 & 531,528 & 5.3 & $7 \mathrm{M}$ & $8 \mathrm{M}$ & $387 \mathrm{~K}$ \\
\hline Ijora/Badia & 118,500 & 48 & 156,420 & 1.6 & $4 \mathrm{M}$ & $2 \mathrm{M}$ & $117 \mathrm{~K}$ \\
\hline Makoko & 85,840 & 36 & 113,308 & 1.1 & $3 \mathrm{M}$ & $2 \mathrm{M}$ & $80 \mathrm{~K}$ \\
\hline Oworonshoki & 78,786 & 33 & 103,997 & 1 & $1 \mathrm{M}$ & $1 \mathrm{M}$ & $73 K$ \\
\hline Ajegunle & 55,200 & 24 & 72,864 & 0.73 & $2 \mathrm{M}$ & $1 \mathrm{M}$ & $53 \mathrm{~K}$ \\
\hline Amukoko & 50,080 & 21 & 66,106 & 0.66 & $2 \mathrm{M}$ & $1 \mathrm{M}$ & $48 \mathrm{~K}$ \\
\hline $\begin{array}{l}\text { Sari } \\
\text { Iganmu/Orile }\end{array}$ & 43,500 & 18 & 57,420 & 0.57 & $1 \mathrm{M}$ & $800 \mathrm{~K}$ & $42 \mathrm{~K}$ \\
\hline Ilaje/Bariga & 20,100 & 9 & 26,532 & 0.27 & $.5 \mathrm{M}$ & $400 \mathrm{~K}$ & $20 \mathrm{~K}$ \\
\hline Iwaya & 15,100 & 6 & 19,932 & 0.2 & $.25 \mathrm{M}$ & $270 \mathrm{~K}$ & $15 \mathrm{~K}$ \\
\hline \multicolumn{5}{|c|}{ Totals: } & $\$ 45 M$ & $\$ 38 \mathrm{M}$ & $\$ 2 \mathbf{M}$ \\
\hline \multicolumn{8}{|c|}{${ }^{1}$ Assuming each toilet serves 100 people, 24 toilets per facility } \\
\hline \multicolumn{8}{|c|}{ ² Assuming 2 flushes/person/day (2.5L/flush) } \\
\hline \multicolumn{8}{|c|}{${ }^{3}$ Calculated acreage needed for 9 day treatment residence time for wastewater } \\
\hline \multicolumn{8}{|c|}{${ }^{4} \$ 45 \mathrm{~K}$ for installation of each sanitation facility, plumbing and septic tank } \\
\hline \multicolumn{8}{|c|}{${ }^{5}$ Price for construction of wetland $\$ 73 \mathrm{~K} /$ acre } \\
\hline
\end{tabular}

\section{Exhibit 8. Capital Costs for Sewage Projects}

Source: Chapter authors.

\subsubsection{Capital Costs for Solid Waste Projects}

Exhibit 9 outlines the total estimated cost of the completion of all selected solid waste projects. Implementation of solid waste management measures in the Iwaya community will 
be accomplished over a 5 year period beginning in 2015 and ending in 2020. The total cost of project implementation in Iwaya will equal \$50,000. Similar solid waste management projects for the 10 remaining inner-city slums of Lagos will be addressed beginning in the year 2020. The total capital cost for implementing designated solid waste projects in the additional 10 communities is $\$ 6,450,000$.

\begin{tabular}{|c|c|c|c|c|c|c|}
\hline Slum & Population & $\begin{array}{l}\text { Total Cargo } \\
\text { Bicycles } \\
\text { Required }^{1}\end{array}$ & $\begin{array}{l}\text { Number } \\
\text { Dinasseur } \\
\text { Trucks } \\
\text { Required }^{2}\end{array}$ & $\begin{array}{l}\text { Cargo } \\
\text { Bike } \\
\text { Price }^{3} \\
\text { (US\$) }\end{array}$ & $\begin{array}{l}\text { Opera- } \\
\text { tional } \\
\text { Cost/Yr } \\
\text { (US\$) }\end{array}$ & $\begin{array}{l}\text { Collection } \\
\text { Transport } \\
\text { Costs/Year }{ }^{5} \\
\text { (US\$) }\end{array}$ \\
\hline Mushin & 633,120 & 760 & 84 & $380 \mathrm{~K}$ & $1 \mathrm{M}$ & $709 \mathrm{~K}$ \\
\hline Agege & 459,939 & 552 & 61 & $276 \mathrm{~K}$ & $730 \mathrm{~K}$ & $515 \mathrm{~K}$ \\
\hline Shomolu & 402,673 & 483 & 53 & $242 K$ & $640 \mathrm{~K}$ & $448 \mathrm{~K}$ \\
\hline Ijora/Badia & 118,500 & 142 & 15 & $71 \mathrm{~K}$ & $188 \mathrm{~K}$ & $127 \mathrm{~K}$ \\
\hline Makoko & 85,840 & 103 & 11 & $52 \mathrm{~K}$ & $136 \mathrm{~K}$ & $93 \mathrm{~K}$ \\
\hline Oworonshoki & 78,786 & 94 & 10 & $47 \mathrm{~K}$ & $125 \mathrm{~K}$ & $85 \mathrm{~K}$ \\
\hline Ajegunle & 55,200 & 66 & 8 & $33 \mathrm{~K}$ & $87 \mathrm{~K}$ & $68 \mathrm{~K}$ \\
\hline Amukoko & 50,080 & 60 & 7 & $30 \mathrm{~K}$ & $80 \mathrm{~K}$ & $60 \mathrm{~K}$ \\
\hline $\begin{array}{l}\text { Sari } \\
\text { Iganmu/Orile }\end{array}$ & 43,500 & 52 & 6 & $26 \mathrm{~K}$ & $69 \mathrm{~K}$ & $50 \mathrm{~K}$ \\
\hline Ilaje/Bariga & 20,100 & 24 & 3 & $12 \mathrm{~K}$ & $31 \mathrm{~K}$ & $25 \mathrm{~K}$ \\
\hline Iwaya & 15,100 & 18 & 2 & $9 \mathrm{~K}$ & $24 \mathrm{~K}$ & $17 \mathrm{~K}$ \\
\hline \multicolumn{4}{|l|}{ Totals: } & $\$ 1.2 \mathrm{M}$ & $\$ 3.1 \mathrm{M}$ & $\$ 2.2 \mathrm{M}$ \\
\hline \multicolumn{7}{|c|}{$\begin{array}{l}{ }^{1} \text { Based on the current } 30 \text { bikes serving } 5000 \text { households, with an average of } 5 \text { people per household } \\
\text { Each bike serves a total of } 833 \text { individuals. }\end{array}$} \\
\hline \multicolumn{7}{|c|}{${ }^{2}$ Based on the assumption that 1 truck will carry the load of 9 tricycles } \\
\hline \multicolumn{7}{|c|}{${ }^{3}$ Based on the average cost to build a tricycle, $\$ 500$ (Recycling as a ramification, 2014) } \\
\hline \multicolumn{7}{|c|}{${ }^{4}$ Based on the current minimum wage of $\$ 1,325$ per year (Labour Threatens, 2014) } \\
\hline \multicolumn{7}{|c|}{$\begin{array}{l}{ }^{5} \text { Based on the given total cost of using a dinasseur truck provided by LAWMA bi-weekly, \$325/tri] } \\
\text { (Standard Tariff, 2011) }\end{array}$} \\
\hline
\end{tabular}

\section{Exhibit 9. Capital Costs for Solid Waste Projects}

Source: Chapter authors.

\subsection{Operation and Maintenance Cost Recovery Plan}

\subsubsection{O\&M Cost Recovery Plan for Sewage Treatment}

In order to properly maintain wastewater treatment systems implemented, an Operation and Maintenance (O\&M) cost recovery plan should be instituted.

- Urban Sewage Infrastructure Maintenance: By implementing low cost, low maintenance systems, this, in turn, will require less funding associated with maintenance of these systems once instituted. To encourage use, it is important to keep sanitation systems clean and in good operational status. These systems, especially toilet facilities, 
will require regular cleaning as well as occasional operational maintenance. Projected funding required for these services can be found in Exhibit 11 above.

- Usage Fees: In order to fund maintenance of communal sanitation facilities, small usage fees will be charged to users on a per family basis. Fee collection schemes will be modeled after those successfully instituted in Bangalore, India, where small usage fees of $\$ 0.02$ per person/per use are used to cover operation and maintenance costs (WSUP, 2011). It is estimated that maintenance costs of $\$ 150$ per toilet seat/year will be required to ensure sanitation facility services are not interrupted. To assist low-income individuals, it is recommended that a credit system be initiated where users can earn toilet facility credits through collection or recycling of solid waste items at the sanitation facility. By encouraging the collection and recycling of solid waste, it is hoped that the community will aid in the cleanup of existing refuse currently clogging drainage canals and impeding transportation efforts in these areas. These strategies are also aimed at promoting the continued, proper disposal of refuse within the slum.

\subsubsection{O\&M Cost Recovery Plan for Solid Waste Management}

The following options are recommended to recover the operation and maintenance costs for solid waste projects.

- Profit Margin Allocation: Funding for O\&M costs will be collected through the profit generated from the selling of accumulated material to recycling processors.

- Industry Sponsorship: Private enterprises will provide funding and resources for the exchange of advertisement. Specifically, sponsors provide cargo bicycles to the initiative that display industry-related adverts. Currently, the Wecyclers initiative has industry sponsors that include the Nigerian Bottle Company, which promotes brands like Coca-Cola, on the side panels of the gifted cargo bicycles (NBC Reassures, 2014).

\subsection{Timing: Implementation Schedule of Projects}

In order to establish sanitation services within low-income areas of Lagos, projects will begin in mid-2015 focusing on the Iwaya slum with a completion date projected in 2020.

The Iwaya slum will be the focus of initial 5-year implementation strategies for both the solid waste and sewage sectors. Focusing on Iwaya will allow for better management and crucial strategies to be refined prior to project implementation in the 10 remaining slums. To assure proper project execution, implementation strategies will consist of three phases; project feasibility studies, project execution and project monitoring (See Exhibits 10 and 11, which follow).

Implementation of sanitation services for the remaining 10 Lagos slum areas will begin in 2020 with construction completion date projected in 2025. 
4.5.1 Implementation Schedules

\begin{tabular}{|c|c|c|c|c|c|c|c|}
\hline \multirow[b]{2}{*}{ Project } & \multicolumn{7}{|c|}{ Year } \\
\hline & 2015 & \multirow[t]{2}{*}{2016} & \multirow[t]{2}{*}{2017} & \multirow[t]{2}{*}{2018} & \multirow[t]{2}{*}{2019} & \multirow[t]{2}{*}{2020} & \multirow[t]{2}{*}{ 2021-2025* } \\
\hline \multicolumn{2}{|l|}{ Provide alternate } & & & & & & \\
\hline \multicolumn{8}{|l|}{ means of } \\
\hline \multicolumn{8}{|l|}{ sewage collection } \\
\hline \multicolumn{8}{|l|}{ Wastewater } \\
\hline \multicolumn{8}{|l|}{ treatment } \\
\hline \multicolumn{8}{|l|}{ Wetland } \\
\hline \multicolumn{8}{|l|}{ Repair } \\
\hline \multicolumn{8}{|l|}{ Existing } \\
\hline \multicolumn{8}{|l|}{ Infrastructure } \\
\hline \multicolumn{8}{|l|}{ Institute sanitation } \\
\hline \multicolumn{8}{|l|}{ operation and } \\
\hline maintenance division & & & & & & & \\
\hline
\end{tabular}

Exhibit 10. Project Implementation Schedule for Sewage Sector

Source: Chapter authors.

Notes:

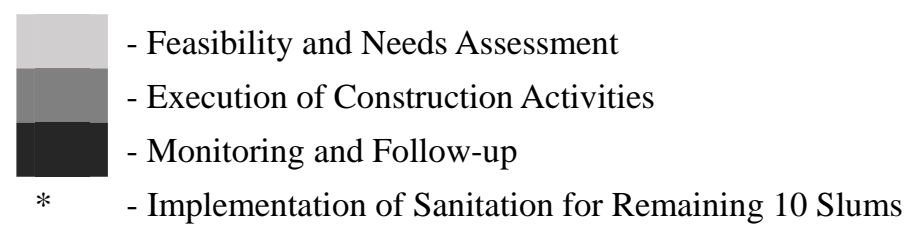




\begin{tabular}{|c|c|c|c|c|c|c|}
\hline \# & 2015 & 2016 & 2017 & 2018 & 2019 & 2020 \\
\hline P1 & $\begin{array}{l}\text { Feasibility } \\
\text { Study }\end{array}$ & $\begin{array}{l}\text { Host local } \\
\text { awareness } \\
\text { campaigns }\end{array}$ & $\begin{array}{l}\text { Host local } \\
\text { awareness } \\
\text { campaigns }\end{array}$ & $\begin{array}{l}\text { Host local } \\
\text { awareness } \\
\text { campaigns }\end{array}$ & $\begin{array}{l}\text { Host local } \\
\text { awareness } \\
\text { campaigns }\end{array}$ & $\begin{array}{l}\text { Host local } \\
\text { awareness } \\
\text { campaigns }\end{array}$ \\
\hline P2 & $\begin{array}{l}\text { Feasibility } \\
\text { Study }\end{array}$ & $\begin{array}{l}\text { +3 Cargo } \\
\text { Bicycles, } \\
\text { + Dinasseur } \\
\text { Truck }\end{array}$ & $\begin{array}{l}\text { +3 Cargo } \\
\text { Bicycles }\end{array}$ & $\begin{array}{l}+3 \text { Cargo } \\
\text { Bicycles,+ } \\
\text { Dinasseur Truck }\end{array}$ & $\begin{array}{l}\text { +3 Cargo } \\
\text { Bicycles }\end{array}$ & $\begin{array}{l}\text { +6 Cargo } \\
\text { Bicycles }\end{array}$ \\
\hline P3 & $\begin{array}{l}\text { Feasibility } \\
\text { Study }\end{array}$ & $\begin{array}{l}\text { Conversion of } \\
\text { Olusosun facility }\end{array}$ & $\begin{array}{l}\text { Monitor } \\
\text { collection, } \\
\text { storage, and } \\
\text { sorting }\end{array}$ & $\begin{array}{l}\text { Monitor } \\
\text { collection, } \\
\text { storage, and } \\
\text { sorting }\end{array}$ & $\begin{array}{l}\text { Monitor } \\
\text { collection, } \\
\text { storage, and } \\
\text { sorting }\end{array}$ & $\begin{array}{l}\text { Monitor } \\
\text { collection, } \\
\text { storage, and } \\
\text { sorting }\end{array}$ \\
\hline P4 & $\begin{array}{l}\text { Feasibility } \\
\text { Study }\end{array}$ & $\begin{array}{l}\text { Useable solid } \\
\text { waste collection, } \\
\text { facility } \\
\text { construction }\end{array}$ & $\begin{array}{l}\text { Waste } \\
\text { collection, } \\
\text { facility } \\
\text { construction }\end{array}$ & $\begin{array}{l}\text { Waste collection, } \\
\text { facility } \\
\text { construction }\end{array}$ & $\begin{array}{l}\text { Waste } \\
\text { collection, } \\
\text { facility } \\
\text { construction }\end{array}$ & $\begin{array}{l}\text { Waste } \\
\text { collection, } \\
\text { facility } \\
\text { construction }\end{array}$ \\
\hline P5 & $\begin{array}{l}\text { Feasibility } \\
\text { Study }\end{array}$ & $\begin{array}{l}\text { Establish } \\
\text { partnership with } \\
\text { SERAC/ } \\
\text { LAMCOFOR }\end{array}$ & $\begin{array}{l}\text { Collaborate } \\
\text { with SERAC/ } \\
\text { LAMCOFOR }\end{array}$ & $\begin{array}{l}\text { Collaborate with } \\
\text { SERAC/ } \\
\text { LAMCOFOR }\end{array}$ & $\begin{array}{l}\text { Collaborate } \\
\text { with SERAC/ } \\
\text { LAMCOFOR }\end{array}$ & $\begin{array}{l}\text { Collaborate } \\
\text { with SERAC/ } \\
\text { LAMCOFOR }\end{array}$ \\
\hline
\end{tabular}

\section{Exhibit 11: Project Implementation Schedule for Solid Waste Sector}

Source: Chapter authors.

Note: $\mathrm{P}=$ Project.

\section{Transportation}

\subsection{Background}

\subsubsection{Lagos Overview}

Lagos is the hub of Nigeria's economic activity. Thus, transportation demand is high, and traffic congestion is a significant and ever more important issue. One of the most influential factors behind the congestion is the geography of Lagos. The financial district of the city is located on an island with few access points. Any disturbances on these main access roads will cause a backup that will affect the entire city. There is a growing need for continued improvement and expansion of the public transportation systems within Lagos in order for it to become less congested. 


\section{MInstitute Macrothink}

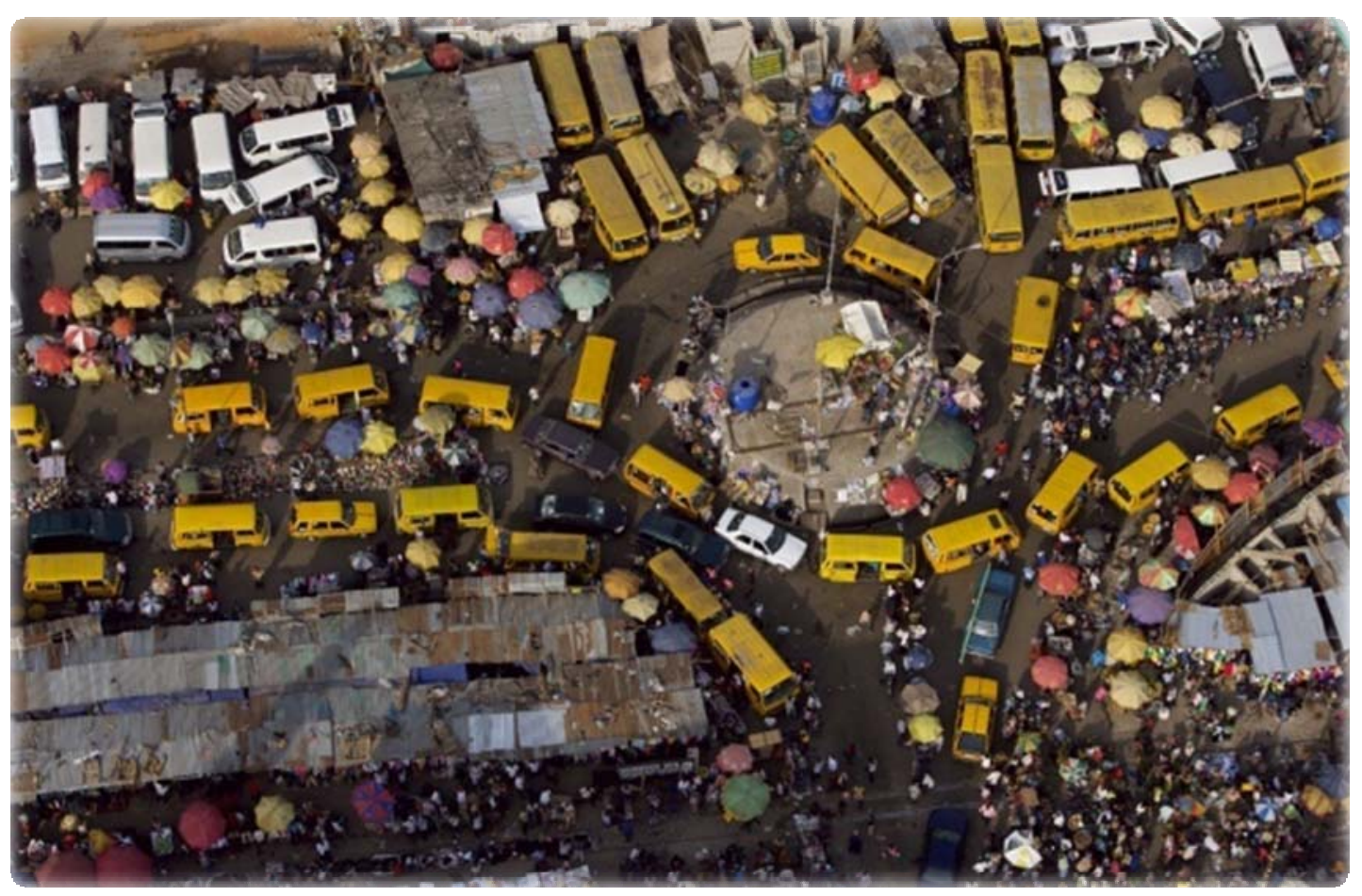

Exhibit 12. Traffic Congestion in Lagos

Source: http://www.archdaily.com/

\subsection{Current LAMATA Projects}

The Lagos Metropolitan Area Transport Authority (LAMATA) is currently implementing 2 transportations plans, LUTP 1 (phase 1) and LUTP 2 (phase 2). LUTP stands for Lagos Urban Transportation Plan. These transportation plans are made up of 5 major components that align with the government transportation strategy: institutional strengthening and capacity building; urban road network efficiency improvement; bus service enhancement; water and non-motorized transport promotion, and rail mass transit.

Within these components, LAMATA plans to strengthen the capacity of the current transportation agencies in order to accommodate future growth. The agency also plans to maximize the capacity of the existing roadways and promote road safety. Within the road network improvements, LAMATA is also focusing efforts on improving the drainage systems in these areas. As it implements these road improvements, the agency is also working on the expansion of the BRT system by adding more BRT lanes to the roadways. Next, LAMATA is promoting alternative modes of transportation that include ferries, bicycles and walking. For these alternative transportation methods, it is encouraging privatization and private sector participation. This idea will help reduce road congestion as well as promote economic development. Finally, LAMATA hopes to increase the amount of rail mass transit within Lagos to decrease travel times and offer a fast, affordable and sustainable mode of transportation. All of these projects are currently being implemented as part of Lagos' 30-year transportation plan. 


\subsubsection{Road Network Improvements}

As part of LAMATA's transportation plans, specific maintenance requirements have been set in place. They are as follows:

\section{Classification of Details of Work} Maintenance

1 Routine

2 Recurrent

3 Periodic

4 Rehabilitation
Work involves drainage clearing to reduce flooding, road sweeping and cleaning, vegetation trimming and haulage of disposable materials.

Work involves filling or sealing of cracks, repair of potholes, treatment of swellings, depressions, etc. on the roads.

Work involves application of asphalt overlays, reconstruction of walkways, road markings and installation of concrete lined drains to control flooding. They also involve some minor Traffic System Measures such as signage and traffic light installation at some junctions.

The rehabilitation work involves reconstruction of pavements and application of an overlay of a 50-millimetre thick hot rolled asphalted wearing course. It also involves the reconstruction of drainage systems, curbs and pedestrian walkways.

\section{Exhibit 13. Road Maintenance Classifications}

Source: LAMATA, 2014.

These maintenance requirements are in place to keep the roadways from deteriorating, as they have in the past. These efforts help in the sustainability and future development of the Lagos road network. 


\section{Macrothink}

\subsubsection{Bus}

The purpose of the Lagos BRT system is to improve transportation accessibility and affordability by facilitating movement along major transportation corridors within the city. There is currently one, $22 \mathrm{~km}$ BRT route in place with more BRT routes planned as part of the master plan for transportation in Lagos. The current route uses 220 buses and moves more than 200,000 passengers a day (LAMATA, 2014) during their hours of operation, i.e., 6:00 am to $10: 00 \mathrm{pm}$. According to LAMATA, the BRT system has been performing respectably since 2008. Since this BRT system has had a higher than expected ridership, LAMATA has been able to reduce fare amounts by $30 \%$. This system has already reduced travel time and waiting time, as well as attracted patrons who generally avoid public transportation, i.e., children, middle-class car owners, the elderly and the disabled.

Along with these positive aspects, the BRT system has provided direct employment for over 1,000 people and indirect employment to over 500,000 people (LAMATA, 2014). Most importantly, this BRT scheme has increased public interest in public transportation and is a key component for future BRT developments.

A map of the BRT routes that are part of Lagos' transportation master plan is shown in Exhibit 14 below.

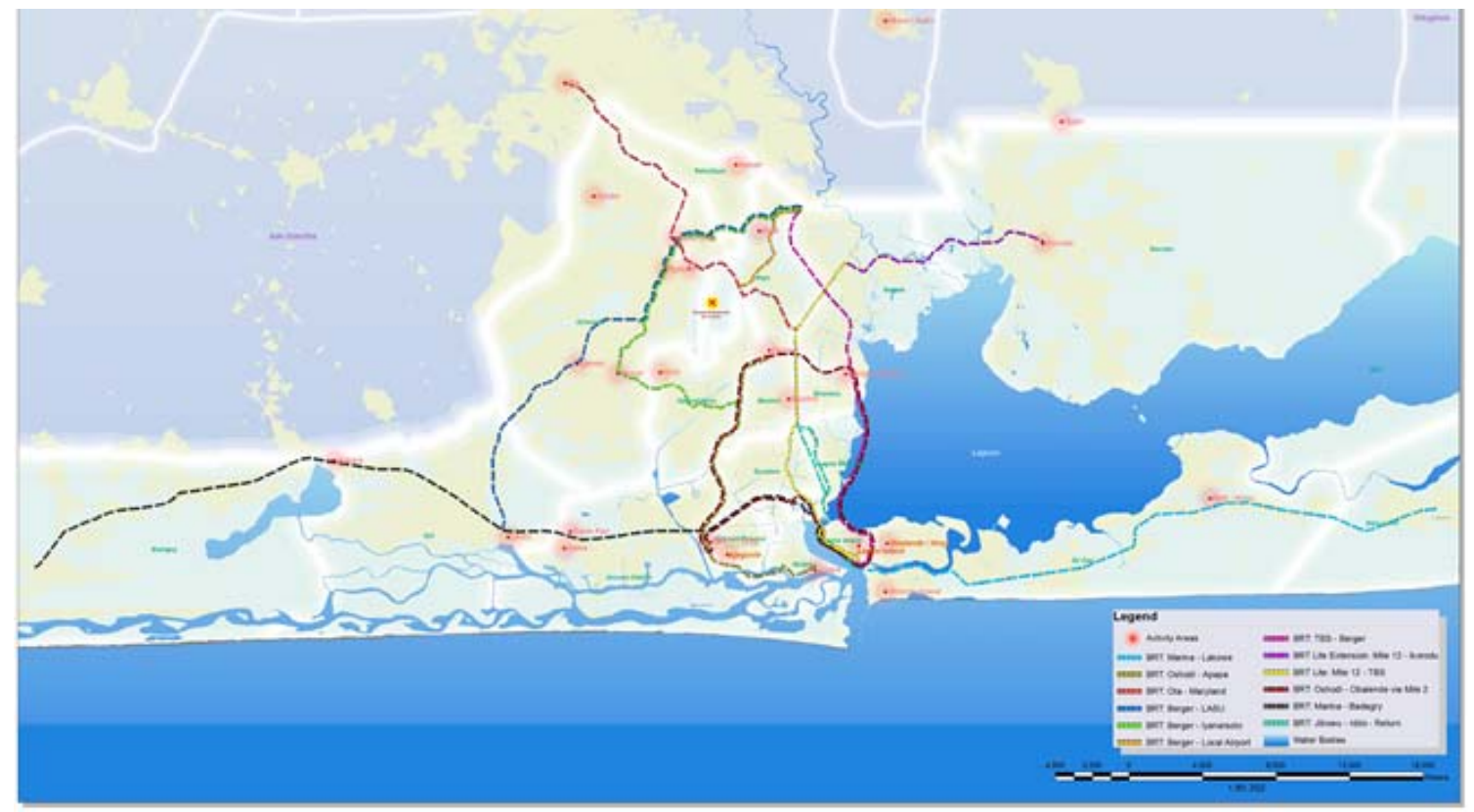

Exhibit 14. Maps of Lagos Bus System

Source: LAMATA, 2014.

\subsubsection{Rail}

The Lagos Urban Rail Network (LURN) is a network of urban rail-based systems within and beyond the Lagos metropolitan area. This network covers 7 major high commuter traffic 


\section{Macrothink}

International Journal of Social Science Research

ISSN 2327-5510

2015, Vol. 3, No. 1

corridors and runs trains that are emission free. Two of the major lines - the red and blue lines - run from high-density urban areas to new developing areas on the outskirts of Lagos. The purpose of these particular rail lines is to accommodate the massive sprawl surrounding the city.

The Blue Line project began in 2009 and is a $27 \mathrm{~km}$ rail line being developed alongside the government-funded 10-lane highway. This plan also includes bus stations and overhead bridges for easy pedestrian access. The China Civil Engineering Construction Company (CCECC), the company that won the "plan poll" and received funding, constructed the Blue Line. According to LAMATA, "CCECC prepared the detailed plan, design and construction workers for the rail infrastructure. These works include stations, roadbed, bridges, permanent way (P-way) tracks works, pedestrian ways and other associated fixed infrastructure (Lagos Rail Mass Transit, 2014).” Exhibit 15 below shows the 7 rail lines in Lagos.

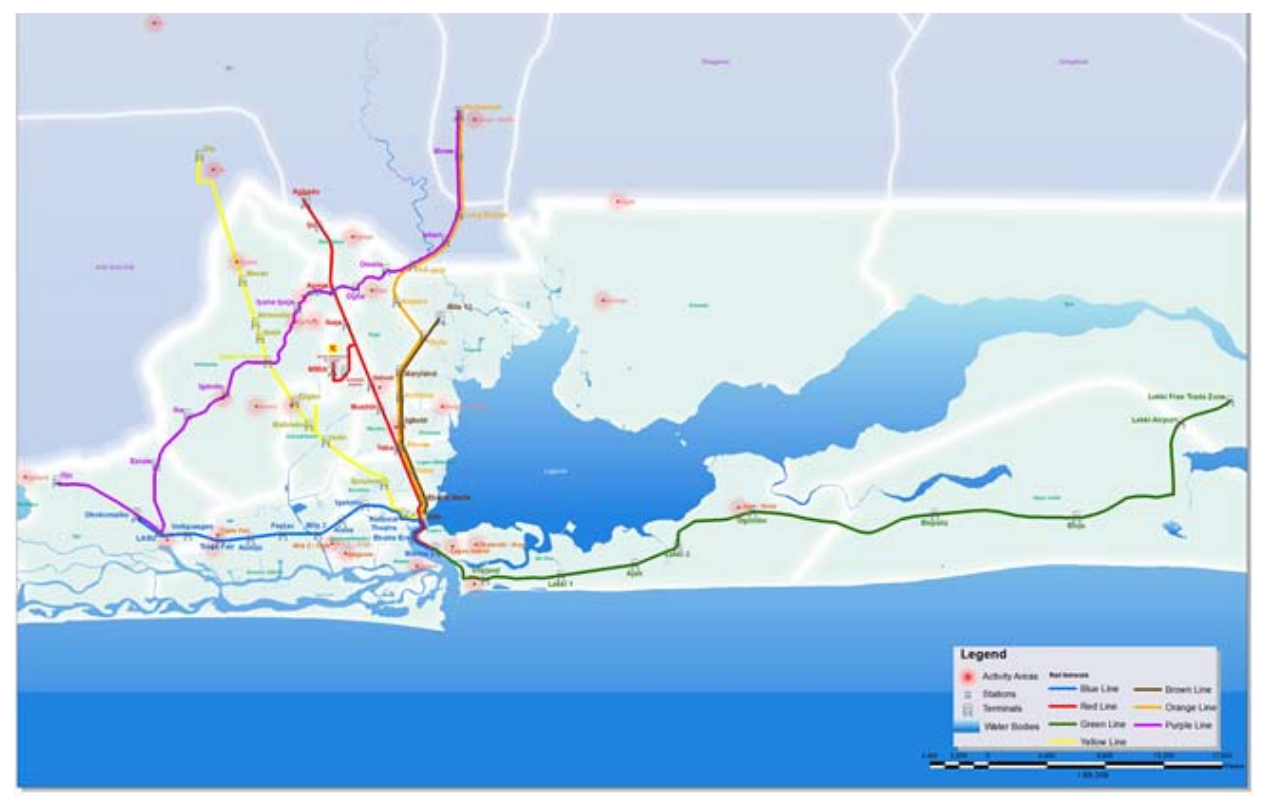

Exhibit 15. Map of Lagos Rail System

Source: LAMATA, 2014.

\subsubsection{Current LagFerry System}

In 2008, LagFerry was granted a license for all ferry routes as defined by the Lagos State Waterways Authority, LASWA (LagFerry, 2014). The hope was that this company would expand and eventually offer a feasible alternate mode of transportation that would minimize traffic congestion on Lagos roadways. Currently, LagFerry has only 3 ferries, i.e., 2 aluminum catamaran ferries and 1 car ferry steel barge with tugboat, which run between 3 locations. These locations include Ikorodu - a local government area, Victoria Island - an affluent neighborhood, and Lagos Mainland - the principal and central governmental area of the Lagos Metropolitan Area. This ferry system is a step in the right direction, but there is 
much room for growth. There are many areas that are not being reached that would benefit from having access to a ferry system.

\subsection{Problem Statement}

Lagos' transportation infrastructure is failing to keep up with the city's rapid population growth. LAMATA has been taking positive steps in dealing with traffic congestion by implementing a 30-year transportation plan, which includes BRT and light rail schemes. However, while Lagos is a port city, the main island is only accessible by 3 bridges. Regardless of the BRT and light rail schemes, there will always be road congestion unless LAMATA implements alternative modes of transportations that are non-land based.

The current ferry system in Lagos is lacking in size and accessibility. The 3-ferry fleet only stops at 3 locations - primarily in wealthier areas. The idea of water transit has great potential in Lagos and could help minimize traffic congestion. This system must be expanded in order to become more accessible and more integrated into the other public transportation systems. This offers potential economic growth and development at the different ports.

\subsection{Recommended Projects}

\subsubsection{Expanding the Ferry System}

The ferry system within Lagos must be expanded in order to help decongest the roadways and offer another affordable mode of transportation. This will be accomplished by constructing 6 new ports, which will integrate with the BRT and light rail systems. Also, 6 new vessels will be added to the current fleet of ferries. These new additions will expand and increase demand for this type of transportation and offer economic development.

\subsubsection{Ports}

As part of the ferry system expansion, 6 new ports are proposed -2 large ports and 4 small ports. Below is a map showing the port locations. The 2 large ports connect 2 high demand areas and will serve as major social and economic hubs. The 4 small ports are placed strategically so as to reach particular points of interest within Lagos. All of these ports will be integrated into the larger transportation system within the city. 


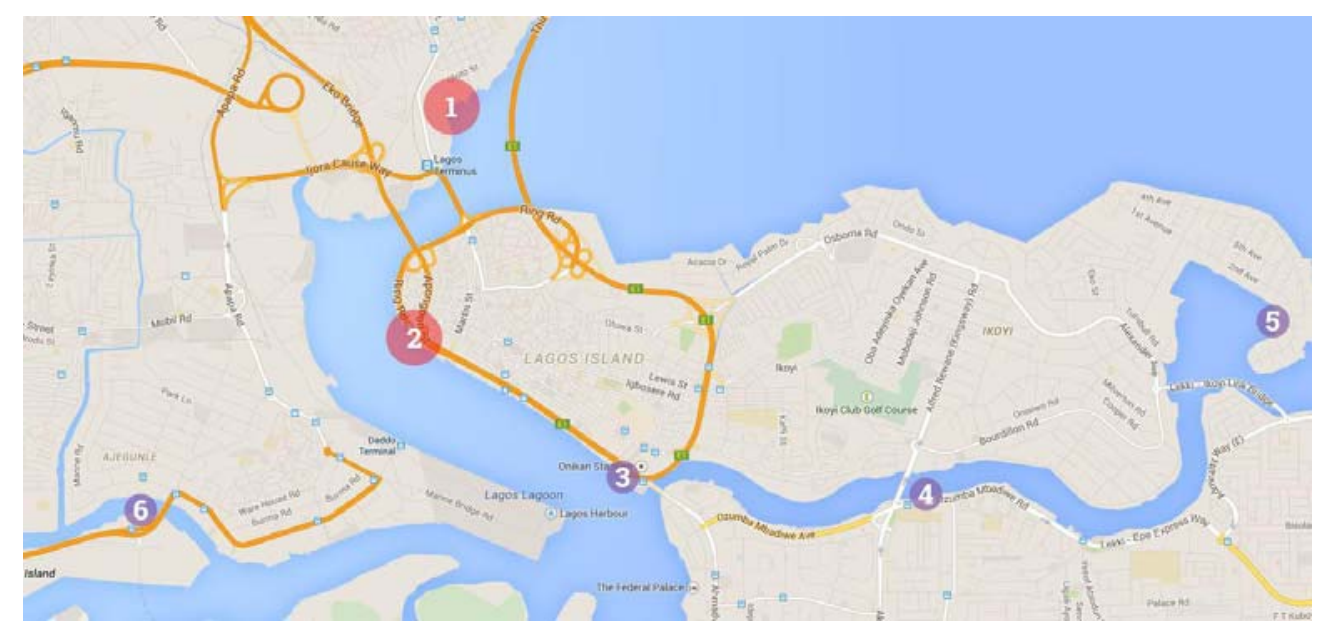

\section{Exhibit 16. Map of Planned Port Locations}

Source: Chapter authors.

\subsubsection{Ferry Fleet}

There are 4 main ferry types, which will be part of the LagFerry fleet: a Fiberglass Passenger Speed Boat, which has 45 seats; an Aluminum Pontoon Water Taxi, which holds 30 passengers; a Steel Ferry, which holds 70 passengers and 11 vehicles, and an Aluminum Catamaran Ferry, which holds 250 passengers and 30 vehicles. As noted above, LagFerry currently has 3 ferries: 2 aluminum catamaran ferries and 1 steel ferry. With the 5-year plan, 6 new ferries will be added to the entire fleet. These include: 1 Fiberglass Passenger Speed Boat; 3 Aluminum Pontoon Water Taxis, and 2 Steel Ferries. Having a range of ferry types will make the ferry system more diverse. There will be ferries that allow for vehicles, which will help attract the middle and upper class residents. There will also be a ferry which can travel at above average speeds, which will draw people in for fast commute times. In the future, more ferries will be added as needed - assuming there is funding available. The ferry system will need to be consistently evaluated to know what types of ferry are in demand.

\subsubsection{Routes}

The proposed routes are as follows:

\begin{tabular}{|l|l|l|l|}
\hline Route & Distance (land miles) & Speed (knots) & Time (min:sec) \\
\hline $1-2$ & 1.9 & 15 & $06: 30$ \\
\hline $1-2-6$ & 6.9 & 20 & $19: 00$ \\
\hline $3-4$ & 2.1 & 20 & $05: 03$ \\
\hline 4.5 & 2.75 & 20 & $07: 00$ \\
\hline
\end{tabular}

Exhibit 17: Proposed Ferry Routes

Source: Chapter authors. 
Route 1-2 will serve primarily as a route for commuters getting to and from work and/or the university area. This route connects to the major downtown area. Route 1-2-6 will also serve primarily as a route for commuters. Ports 2 and 6 are the 2 main hubs for workers so this route will provide a feasible and affordable option to get to and from jobs. Route 3-4 will connect the university area to the cultural center. This will allow students the ability to travel with public transportation, especially since the ferry system will be interconnected to the bus system. Route 4-5 will connect the main tourist area with the cultural center. This will serve as an attractive way for tourist to tour the city and get to all the places they would like to go. All of these routes are connected and will allow users to get to any of the ports, no matter what port their trip is beginning at. As demand increases, new routes will also be considered.

\subsubsection{Connecting to Existing Transportation}

Each of the ports will be connected or in close proximity to a bus station. If there is not a bus station in that area currently, a new bus station will be constructed, and a new bus route will be added. This will allow the ferry system to become integrated into the larger transportation system of Lagos. Having the ferry system part of the whole will help eliminate the number of people on the road. It will provide a feasible mode of transportation — one much faster than any other current mode - that is also connected to all major points within the city.

\subsubsection{Introduce Small Business Opportunities}

Within and around the proposed ports and bus stops, there will be opportunities for vendors and local business owners to have shops to sell goods to those using public transportation. There is also an opportunity to create public/private partnerships with taxis, both on water and land. Since public transportation does not reach every inch of the city, there is an opportunity for private entrepreneurs to begin a taxi service to serve the needs of the population. These taxis would be stationed at the ports and would be in place to take people to their desired locations.

\subsubsection{Costs}

LagFerry, the Lagos Ferry Services Company, estimates that 1.8 million passengers use water transportation each month to get around the city. That is approaching $10 \%$ of the population. With the new ferry system in place, along with improvements in land transit, the use of public transportation is sure to rise and cater to the rapidly growing population of Lagos. Most of the funding will be private because the costs are lower than normal.

\section{Ports}

The proposed ports for Lagos come in 2 different sizes. One is a larger port of 10 thousand square feet and the other a smaller port of 5 thousand square feet. The larger ports will be able to hold 2 ferries (traditionally one larger ferry and one smaller ferry), and the smaller ports will house 1 smaller ferry. The ports will be simply constructed and be made of basic materials and utilize traditional construction methods. The ports are simple covered areas for passengers to wait for a ferry or bus, or where they can buy goods from various vendors around the port. Space inside and around the ports will be rented to vendors to generate more 
revenue for the LagFerry company.

Small Port Costs (USD)

\begin{tabular}{|l|l|}
\hline Materials & $\$ 1,000$ \\
\hline Labor & $\$ 500$ \\
\hline Construction & $\$ 5,000$ \\
\hline Land (\$7 per sq. foot) & $\$ 35,000$ \\
\hline Other Costs & $\$ 8,500$ \\
\hline Total & $\mathbf{\$ 5 0 , 0 0 0}$ \\
\hline
\end{tabular}

Exhibit 18. Small Port Costs

Source: Chapter authors.

\section{Large Port Costs (USD)}

\begin{tabular}{|l|l|}
\hline Materials & $\$ 2,000$ \\
\hline Labor & $\$ 1,000$ \\
\hline Construction & $\$ 10,000$ \\
\hline Land (\$7 per sq. foot) & $\$ 70,000$ \\
\hline Other Costs & $\$ 17,000$ \\
\hline Total & $\mathbf{\$ 1 0 0 , 0 0 0}$ \\
\hline
\end{tabular}

Exhibit 19. Large Port Costs

Source: Chapter authors.

\section{Ferry Boats}

As stated earlier in this section, there are 3 types of ferries for Lagos' new transportation plan. Below is the breakdown of costs, capacity and other important information about each ferry. The boats total over half the cost of the entire project, but they are still affordable for the city and the passengers. Keeping the price of the ferries down will allow for lower fares and cheaper maintenance costs. The ferries are made by a manufacturer and boat vendor called Scruton Marine in Port Dover, Ontario, Canada. All ferry models are built in Canada. 


\begin{tabular}{|l|l|l|l|l|l|}
\hline Type & Capacity & $\begin{array}{l}\text { Max } \\
\text { Speed }\end{array}$ & $\begin{array}{l}\text { Price } \\
\text { (USD) }\end{array}$ & $\begin{array}{l}\text { Proposed } \\
\text { Number }\end{array}$ & Total Cost \\
\hline $\begin{array}{l}\text { Fiberglass } \\
\text { Passenger } \\
\text { Speed } \\
\text { Boat }\end{array}$ & $\begin{array}{l}45 \text { seats, } \\
\text { more space } \\
\text { to stand }\end{array}$ & $\begin{array}{l}22 \\
\text { knots }\end{array}$ & $\$ 350,000$ & 1 & $\$ 350,000$ \\
\hline $\begin{array}{l}\text { Aluminum } \\
\text { Pontoon } \\
\text { Water } \\
\text { Taxi }\end{array}$ & $\begin{array}{l}30 \\
\text { passengers }\end{array}$ & $\begin{array}{l}12 \\
\text { knots }\end{array}$ & $\$ 40,000$ & 3 & $\$ 120,000$ \\
\hline $\begin{array}{l}\text { Steel } \\
\text { Ferry }\end{array}$ & $\begin{array}{l}70 \text { seats, } 11 \\
\text { vehicles }\end{array}$ & & $\$ 85,000$ & 2 & $\$ 170,000$ \\
\hline
\end{tabular}

Exhibit 20. Ferry Types

Source: Scruton Marine, 2014.

The total cost of ferries in this 5-year plan is approximately $\$ 640,000$. This is $60 \%$ of the total amount needed for the project. LagFerry will expand and have private investors to invest in the vessels along with funding from the World Bank. The World Bank has a special window for purchases of Canadian goods and services for use in development projects, which is proposed to be utilized. There are other windows in the bank financed by other developed countries for the purchase of their goods and services on World Bank projects, but the desired vessels here are Canadian.

\section{Bus System}

The goal of the new bus stops is to connect the ferry transportation system with the bus and rail networks. These new bus stops and bus routes will allow for quicker travel times and more options for getting around Lagos. LAMATA has already received new busses as of January 2015, so the only new proposal here is to add new bus stations and expand the routes with LAMATA. Each bus station will cost about \$1,200.

New transportation stations will be built to integrate the ferry system into the land travel system. This integration will allow the ferries to become a feasible option for those who need to reach further inland. In Exhibit 21 below is a simple breakdown of the cost per bus station. 


\begin{tabular}{|l|l|}
\hline Materials & $\$ 700$ \\
\hline Labor & $\$ 470$ \\
\hline Total per Station & $\$ 1,170$ \\
\hline Total for Project & $\$ 7,020$ \\
\hline & \\
\hline
\end{tabular}

\section{Exhibit 21. Cost per Bus Station}

Source: Chapter authors.

The bus stations are simple, much like the small ferry ports. These provide shelter from rain and a place to sit or stand and wait for a bus. Bus stations will be placed within walking distance of each port. Having more options for public transportation increases the probability that more people will use it. Connectivity is one of the most important aspects of planning for a city, especially a city like Lagos that has such a rapidly growing population.

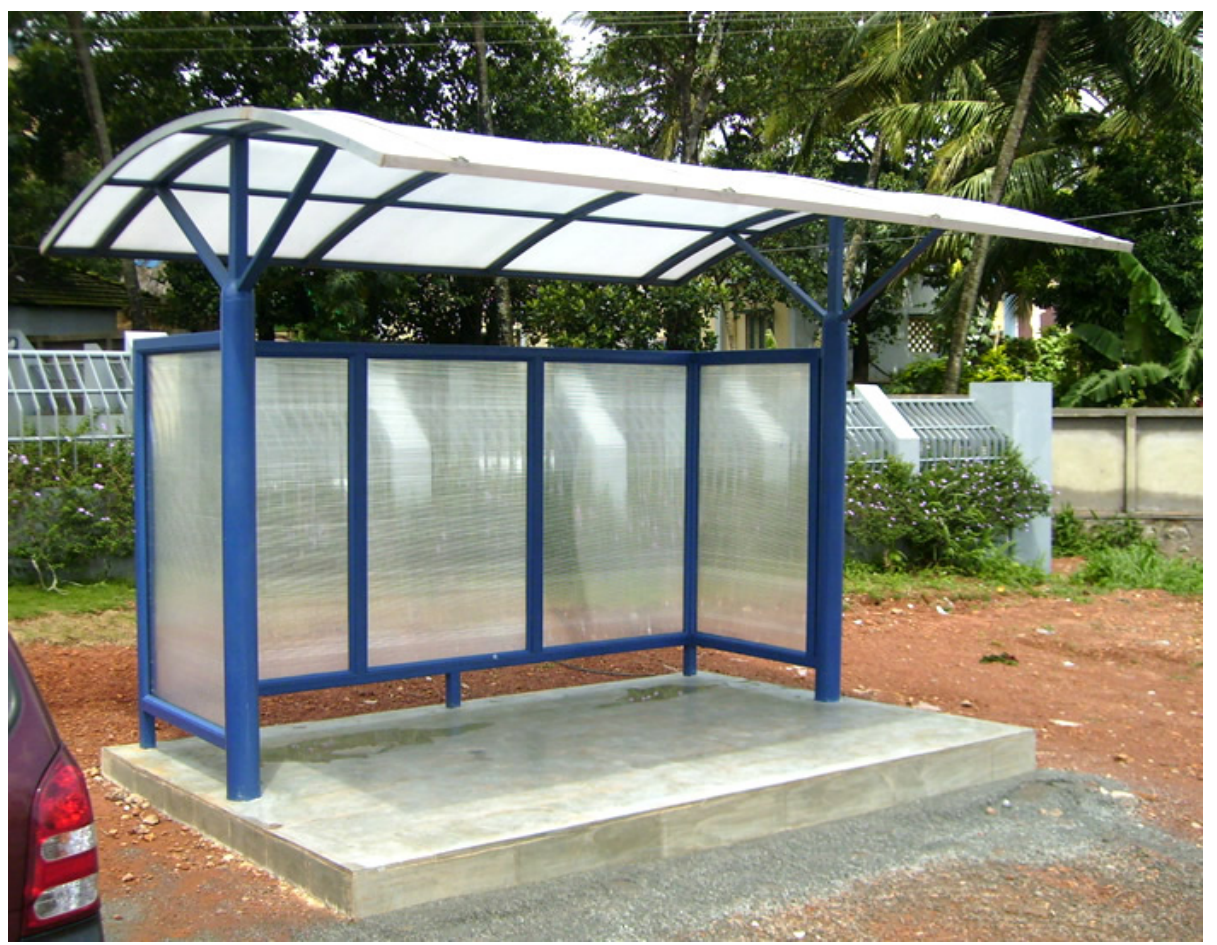

Exhibit 22. Simple Bus Waiting Station

Source: Sherbrooke Architects, India, EMBARQ, 2014.

\subsubsection{Funding and Loans}

The majority of the funding for this project is expected to come from World Bank funds for infrastructure projects, utilizing the bank's Canadian window to assist in the purchase of the 


\section{Macrothink}

Canadian-manufactured ferries. Moreover, private investment should be simple and fast for a relatively small project like this one. LAMATA can invest its own money in the bus waiting stations, or get a local company in Lagos to invest. LagFerry will expand its fleet of ferries and ports under this plan, so it can also invest some of its own money for the ferries as well. The ports are a larger investment, however, and will likely depend on the infrastructure funding of the World Bank. The fares for busses and ferries are expected to pay back the loans in a 10 year period because of the projected number of people using public transportation.

\subsubsection{Maintenance and Fares}

Maintenance fees will be covered by passenger fares. The current fees that LagFerry charges for its ferry service will be reduced to increase popularity and use. In Exhibits 23 and 24 below are the current and proposed fares for LagFerry.

\begin{tabular}{|l|l|l|l|}
\hline Trip & Adult & Student & Child (5 \& under) \\
\hline One Way & N400 & N 00 & Free \\
\hline Round Trip & N700 & N500 & Free \\
\hline
\end{tabular}

Exhibit 23. Current Fares with LagFerry, Lagos.

Source: LagFerry, 2014.

Note: \$1 = N183.4 (January 13, 2015)

\begin{tabular}{|l|l|l|l|}
\hline Trip & Adult & Student & Child (5 \& under) \\
\hline One Way & N100 & N75 & Free \\
\hline Round Trip & N175 & N125 & Free \\
\hline & & & \\
\hline
\end{tabular}

Exhibit 24. Proposed Fares with LagFerry, Lagos

Source: Chapter authors.

Note: \$1 = N183.4 (January 13, 2015)

As can be seen above, the price for a one way adult ticket are proposed to go from approximately $\$ 0.50$ to $\$ 2.25$. This makes the water transit system affordable for almost everyone in the city.

Consequently, if 1.5 million people use water transportation each month, Exhibit 25 below summarizes the payback periods for the ports and ferries. The table assumes that $60 \%$ of users are adults, $30 \%$ are students, and $10 \%$ are children taking only one-way trips. This calculated according to the 5-year plan. 


\begin{tabular}{|l|l|}
\hline $\begin{array}{l}\text { COSTS } \\
\text { Amount Owed: Boats }\end{array}$ & $\$ 640,000$ \\
\hline Amount Owed: Ports & $\$ 400,000$ \\
\hline Total Amount Owed & $\$ 1,040,000$ \\
\hline $\begin{array}{l}1.5 \quad \text { million users } \\
\text { REVENUE }\end{array}$ & $\$ 685,000$ \\
\hline Other costs per month & $\$ 400,000$ \\
\hline Earnings per month & $\$ 285,000$ \\
\hline Payback Period & $\mathbf{4}$ months \\
\hline
\end{tabular}

\section{Exhibit 25. Payback Period for Ports and Ferries}

Source: Chapter authors.

\subsubsection{5-Year Plan Proposal}

This proposed 5-year plan will be implemented according to the following timeline:

\section{Year 1:}

- $\quad$ Build ports 1 and 2;

o Costs: $\$ 100,000 \times 2=\$ 200,000$

- Build bus stations associated with these ports;

o Costs: $\$ 1,170$ x $2=2,340$

- Purchase 1 water taxi, and

o Cost: $\$ 40,000$

- Lease out property of ports to small businesses $\rightarrow$ begin economic development in these areas.

- Total cost for Year 1: $\mathbf{\$ 2 4 2 , 3 4 0}$

Year 2:

- Complete general assessment of the usage of the ferry systems at ports 1 and 2;

- Build ports 3 and 4 o Cost: $\$ 50,000 \times 2=\$ 100,000$

- Build bus stations associated with these ports, and o Cost: $\$ 1,170$ × $2=2,340$

- Purchase two water taxis.

o Cost: $\$ 40,000 \times 2=\$ 80,000$

- Total cost for Year 2: \$182,340

Year 3:

- Assess the demand and usage of ferry system to date;

- Build ports 5 and 6;

o Cost: $\$ 50,000$ × $2=\$ 100,000$

- Build bus stations associated with these ports;

o Cost: $\$ 1,170$ x $2=2,340$ 
- Purchase 1 passenger speed boat, and o Cost: $\$ 350,000$

- Conduct general assessment of the BRT and light rail systems and how effective they have been in the past 3 years since their completion.

- Total cost for Year 3: \$452,340

Year 4:

- Purchase 1 steel ferry; o Cost: $\$ 85,000$

- Assess all ports; begin to expand port space as needed, and

- Assess the small businesses that are located at the ports and evaluate their effectiveness in terms of economic development and future growth.

- Total cost: $\mathbf{\$ 8 5 , 0 0 0}$

Year 5:

- Reach out to private investors with regard to private taxi services, both water and land, which will be integrated into the larger transportation system. This will allow the entire public transportation system to become more interconnected, and

- Assess the ferry system with the bus system; see where there is potential for more routes that would be beneficial to the public.

\section{ENERGY}

\subsection{Background}

As the population of Lagos grows exponentially, energy demand is climbing to new heights. Nigeria's energy production, on the other hand, has struggled to keep up with the growing needs of Lagos and the country as a whole. Nigeria suffers from the peculiar paradox of being an energy rich country in an energy crisis. Oil reserves are the highest in Africa, yet many residents of Lagos do not have reliable electricity in their homes, and industries are challenged with a volatile energy grid. The fate of Lagos rests on its ability to supply reliable energy as demand grows rapidly in the urban area.

\subsection{Lagos's Energy Demands}

In Lagos, total energy demand for residential, commercial and industrial use is estimated to be at least 10,000 MW. Lagos' energy supply from the national electricity grid, however, is optimistically 2,250 MW (Adenikinju, 2013). The stark gap between supply and demand is being met through widespread use of private generators. A recent audit of 13,000 residential, commercial and industrial locations by the Lagos State Electricity Board (LSEB) revealed the presence of 17,000 private generators in use. This suggests that every location in Lagos has at least 1 private generator (MEMR/LSEB, 2013). Private generators run on diesel fuel and are estimated to consume "approximately 162,000 litres of diesel a day, resulting in 178 lbs. of $\mathrm{CO}_{2}$ being emitted per household per day (Ibid.).” Additionally, the cost of private electricity generation, or self-generation, is estimated at 4 times the price of electricity from the national grid.

Although the lack of reliable electricity in Lagos affects the lives of all residents, its greatest 
impact is on industries. A survey of manufacturing firms in Nigeria shows that only $6.2 \%$ rely exclusively on electricity from the national grid (Aliyu, 2013). The remaining 93.8\% supplement their supply through self-generation and experience losses in productivity and output, as well as increased energy expenditures, as a result (Ibid.). Reginald Odia, Chairman of the Infrastructure Committee of the Manufacturers Association of Nigeria, claims that because of the high energy costs in Nigeria, the cost of production is " 9 times that of China and 4 times that of Europe” (Business Day, 2009). The failure of the national grid to supply adequate electricity stifles industrial growth and stunts the economic development of this already struggling country.

Given the scarcity of supply from the national grid and the added environmental and financial costs of private generator use, it is imperative for Lagos to reach its own state-run solution to the electrical energy problems plaguing the city. LSEB has sought to improve Lagos's electricity production with the introduction of several small-scale natural gas-burning independent power plants (IPPs). By the end of 2014, it is expected that 6 IPPs will provide 48.7 MW for Lagos government buildings and services (Bassey, 2014). Although these plants do not provide electricity for consumers, they do help relieve some of the burden currently placed on the national grid.

\subsection{Priorities}

\subsubsection{City-wide Electricity Coverage}

While LSEB has been aggressive in its attempts to fill the gap between supply and demand, the 7,750 MW needed to reach current demand will not materialize overnight. In the meantime, Lagos's demand for electricity will continue to rise. Consequently, public-private partnerships between the local government and independent industrial plants can enable small-sized power plants to provide efficient energy for industries. Additionally, recently developed technology in photovoltaic solar panels allows for affordable solar power for small businesses and low-income communities that cannot access energy from power plants, providing them with reliable and sustainable energy. Utilizing waste items produced locally as an input for energy production has a significant potential for providing the low-income communities with energy, as well as reducing waste and inherent environmental problems.

\subsubsection{End User Efficiency Enhancement}

Efforts towards improving Lagos' energy system must include efficient methods of energy conservation and the maintenance of energy sources. With the rapid development of end user technologies such as passive cooling, illumination, day lighting strategies, mechanical operation and automated systems, energy conservation can be incorporated into public and private buildings. Training individuals or groups from local communities to use and maintain energy sources helps communities and the Lagos State as a whole to sustain their energy needs. While the immediate capital cost requires additional consideration, not only are the profits immense in the long run, but the need for new generation facilities or the search for alternative energy resources can also be eliminated. 


\section{Macrothink}

\subsection{Selected Projects}

This section presents several projects as a means of increasing electrical capacity for industries, residential areas and small commercial enterprises. The options focus on increasing Lagos State's energy independence and security, while also making sure to utilize renewable energy sources and reduce energy usage wherever possible. The following sections present each technical option to be considered, along with details on project costs, proposed funding agents, operation and maintenance expenses, and an implementation timeline.

\section{Project 1: Independent Power Plants for Industries (Highest Priority) (\$76,700,000): Proposed Funding Agent: Fidelity Bank of Nigeria}

Lagos has already built 6 independent power plants that currently provide 48.7 MW of dedicated electricity to government-operated buildings (Bassey, 2014). Using this existing concept, this project will expand IPPs to provide electricity for industries as well. Reliable, dedicated electricity will help attract industries to Lagos, make them more competitive globally, increase their production, eliminate their burden on the national grid, and reduce their dependence on diesel self-generation.

This project is modeled on the Akute Power Plant, shown below in Exhibit 30. Built in 2009, this IPP is fueled by natural gas and currently provides $12.15 \mathrm{MW}$ of power for the Lagos Water Corporation. Akute is a public-private partnership between Lagos Water Corporation and Akute Power Limited, a project company created by Oando Gas \& Power, the developer of much of Nigeria's natural gas pipeline (Akute Power Limited, 2014). The plant was constructed in 12 months at the cost of $\$ 25.5$ million, which was supplied by Fidelity Bank of Nigeria (Again, 2014).

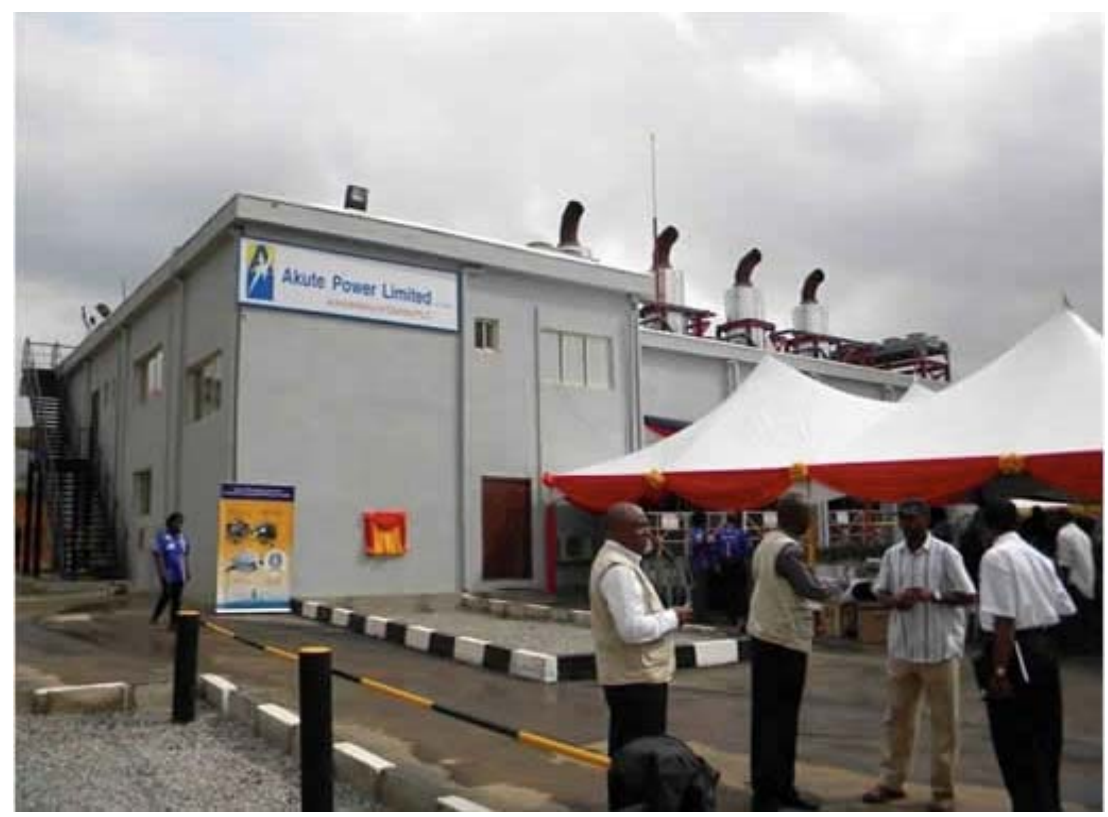

Exhibit 26. Akute Power Plant

Source: Lagos State Public-Private Partnership Office, 2014. 
The construction of 3 new natural gas-fired IPPs, each of which will provide dedicated power to one or more industries, is recommended here. The first will be located in the Lekki Free Trade Zone and provide 12MW of power for the pharmaceutical plant that will be built there (See Section 3: Industry). After the construction of the first plant, 2 site studies will take place to find suitable locations and industrial partnerships for 2 more $12 \mathrm{MW}$ IPPs. Once the locations and partners have been chosen, the plants will be constructed over the next 2 years. This will increase total electrical capacity in Lagos by $36 \mathrm{MW}$ and provide support for at least 3 industries.

Each plant will be a public-private partnership between the Lagos State government (LASG) and the natural gas distribution company, in the case of Lekki Industrial Plant, Oando Gas and Power. The plants will operate on a 5-year build-operate-transfer (BOT) agreement between the 2 partners. For the first 5 years of operation, the gas distribution companies will control the plant and receive all profits. After 5 years, ownership will be transferred to LASG, which will control the plant in perpetuity. Fidelity Bank, the funding agent for the Akute Power Plant and several other IPPs, is expected to provide the funding for this project as well.

\section{Project 2: Landfill Gas to Energy (\$277, 200); Proposed Funding Agents: Federal Ministry of Environment; United Nations Development Programme}

Given that Lagos generates about 9,000 tons of municipal solid waste per day, the excessive amount of waste requires effective management at dumpsites both within and on the outskirts of the city. Communities living in the vicinity of such areas happen to be the low-income class without access to electricity and are exposed to a source of health hazards.

Looking at a smaller scale, the issue can be solved with locally based energy generation from waste in rural areas and low-income neighborhoods. The aim is to establish an integrated waste management strategy to reduce waste, generate energy and improve livelihoods, using a small-scale bio-digester and generator system to convert organic waste into electricity and fertilizer. Each plant has the capacity of $0.001 \mathrm{MW}$, enough to provide efficient and affordable energy to the local communities, as well as help with waste management and environmental improvement. 


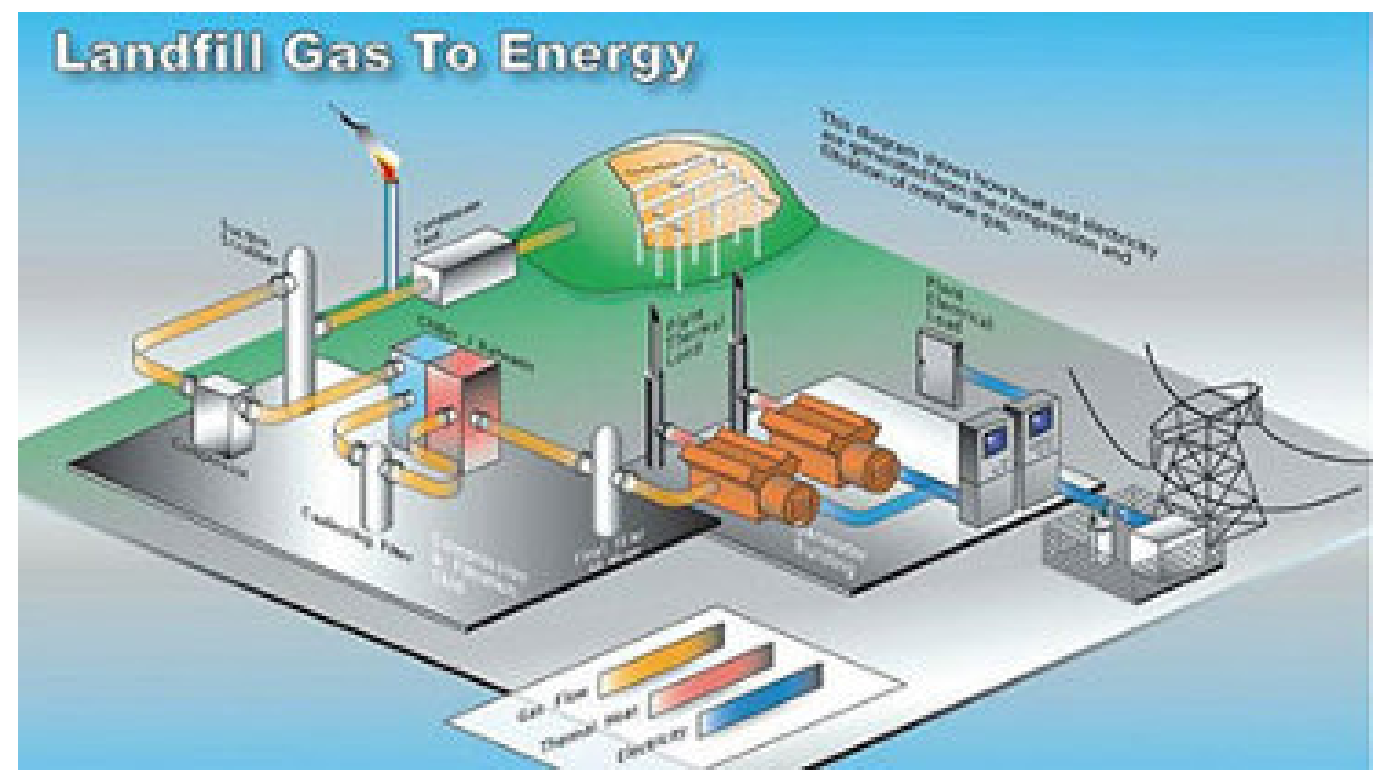

Exhibit 27. Landfill Gas to Energy Diagram

Source: Msimire, 2012.

The first stage is to begin a pilot project in Iwaya and Makoko, 2 of the low-income areas of Lagos, starting with the construction of landfill gas to energy plants at locations close to landfills and wetland areas. The next stage is operation, training a local group of people to run and maintain the facility, following optimization testing. The development stage is then to take place after the initial 5-year plan, aiming to extend the same model to other low-income areas in Lagos.

Project 3: Floating Houses with Solar Panels (\$1,800,000); Proposed Funding Agents: United Nations Development Programme, Federal Ministry of Environment, Heinrich Bold Foundation

Since Lagos is provided with an abundance of intense sunlight throughout the year, the state has an advantage for solar power. This source of energy is the optimal solution to provide electricity to off-grid communities that live on water in Lagos Lagoon. By rebuilding floating houses that include solar panels installed on top of the roof, efficient and independent energy can be provided for the community. 


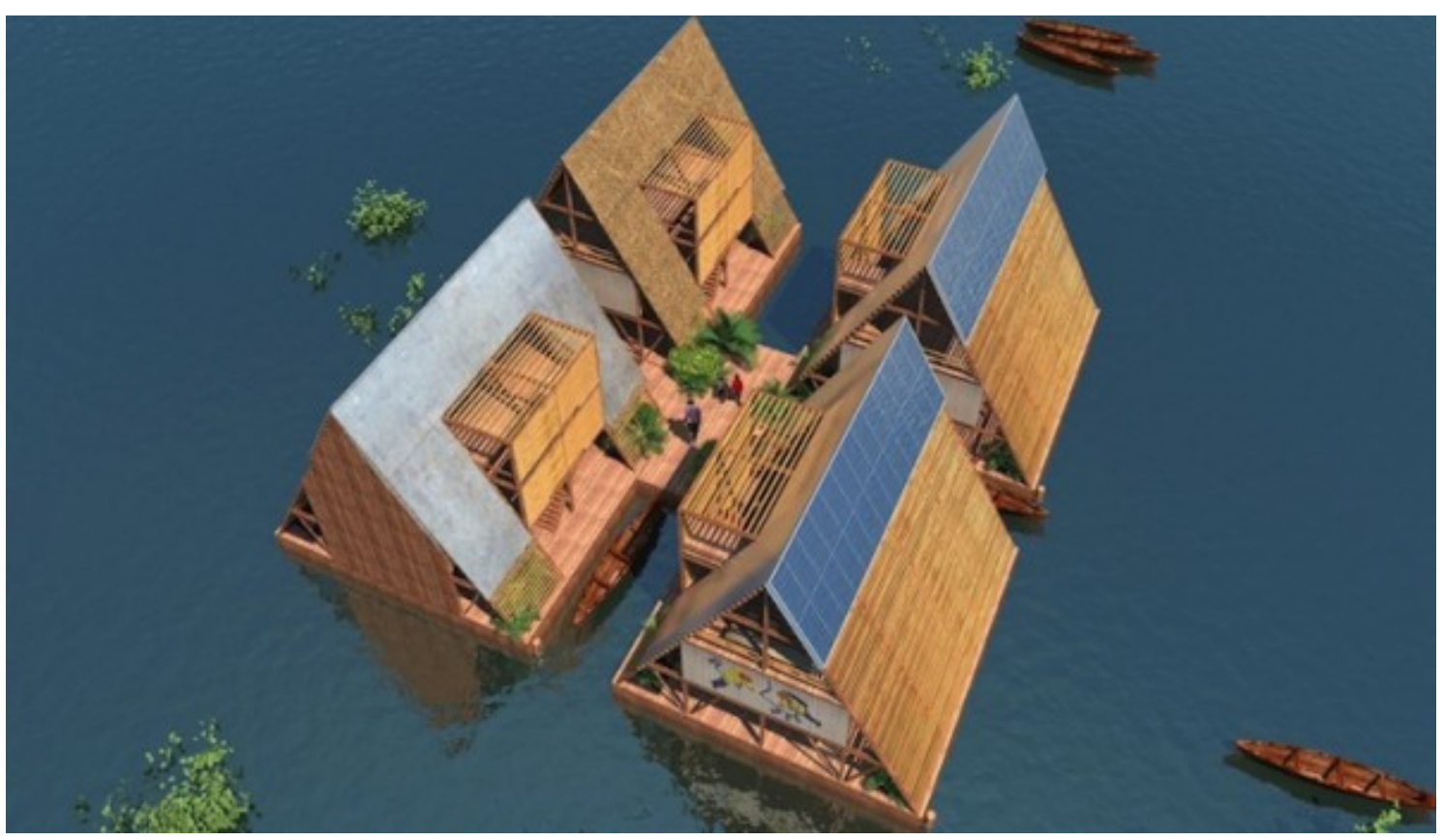

Exhibit 28. Model of Floating Houses with Solar Panels

Source: NLÉ Architects, 2014.

The first stage is to begin a pilot project in Makoko, where the majority of low-income communities live near or on water without access to energy resources. Construction of floating houses from locally made and recycled materials is accompanied with installation of photovoltaic solar panels, also locally produced. Following the first stage is the testing and maintenance within the Makoko community. The project then proceeds to continue building and operating solar floating houses on a city-wide scale.

\section{Project 4: Solar panels for small businesses $\mathbf{( \$ 2 2 , 8 0 0 , 0 0 0 )}$; Proposed Funding Agent: Lagos State Electricity Board}

Solar power provides energy reliability, energy independence, and is economical in the long run; therefore, it is an optimal solution for Lagos small businesses that cannot access energy from the national grid or independent power plants. With new technology recently developed, photovoltaic solar panels now come in pallets of multiple panels, providing economical options for businesses.

It is proposed that Lagos Electricity Board provide subsidies for solar panel installation and operations training for small businesses, in order to create an incentive for solar energy. The project will continue past the 5 year time span, continuously subsidizing solar panels until a desired number of businesses are equipped with solar panels efficient enough for their energy needs. 


\section{Macrothink

Project 5: Incandescent Light Bulb Replacement Program (\$680,000): Proposed Funding Agent: International Development Association

Incandescent light bulbs, in widespread use around Nigeria, are highly inefficient in their energy use, giving off most of their consumed energy in heat instead of light. Compact fluorescent lamps (CFLs) are much more energy efficient, helping to reduce energy used for lighting by $67 \%$. CFLs also last 7 to 10 times as long as incandescent bulbs (Johnson, 2012).

Unfortunately, CFLs also cost more than their incandescent counterparts, and many Nigerians can't justify this initial investment or properly measure the benefits of CFLs. To make the problem worse, there is a proliferation of inexpensive, but low-quality CFLs on the market that break easily and do not last nearly as long as high-quality CFLs (Ibid.). The proliferation of low-quality CFLs has given these bulbs a bad reputation among the public. To help improve the reputation of CFLs and advertise their benefits, this project will launch an incandescent replacement program in several neighborhoods, and use the program as a public relations campaign to promote CFL usage in other neighborhoods.

This project will be overseen by LSEB, and begin with a 6-month survey to find a proper site or sites for the replacement of 100,000 incandescent bulbs with CFLs. The site must have access to electricity and presently have a high-use of incandescent lamps. After site selection, a 2 to 3 month replacement of 100,000 incandescent bulbs with CFL will take place. The replaced bulbs will also be properly disposed of. Next, a 3-year study will take place to assess the benefits such as lower energy use and longer bulb life that were realized through the project. This information will be used to launch a public awareness campaign designed to promote CFLs in other neighborhoods of Lagos. This project is expected to receive funding from the International Development Association, which has provided funding for similar light bulb replacement programs around Africa (World Bank, 2010).

\subsection{Capital Costs}

The estimated prices for the projects are summarized below:

\section{Project 1: Independent Power Plants for Industries}

- $\$ 76,700,000$

o $\$ 76,500,000$ - Construction of 3 IPPs

o $\$ 200,000-2$ site surveys

Project Total: \$76, 700,000

Proposed Funding Agent: Fidelity Bank of Nigeria

\section{Project 2: Landfill Gas to Energy}

- $\$ 6,600$ - Cost per plant, including:

o Locally fabricated bio-digester

o 10vVA generator

o Construction/ Installation costs

o Yearly maintenance

- $\quad$ Number of plants (Iwaya + Makoko): 42

Project Total: $\$ 277,200$ 
Proposed Funding Agents: Federal Ministry of Environment; United Nations Development Programme

\section{Project 3: Floating Houses with Solar Panels}

- \$360,000 - Makoko Community, including:

o 200 \$1,800 individual housing units

- Total number of communities: 5

- Test and maintenance: $\$ 50,000$

Project Total: \$1,850,000

Proposed Funding Agents: United Nations Development Programme; Federal Ministry of Environment; Heinrich Bold Foundation

\section{Project 4: Solar Panels for Small Businesses}

- $\$ 57,000,000-10,000$ small businesses

- $40 \%$ subsidies: $\$ 22,800,000$

Project Total: $\$ 22,800,000 / 5$ years

Proposed Funding Agent: Lagos State Electricity Board

\section{Project 5: Incandescent Light Bulb Replacement Program}

- $\$ 680,000$

$$
\begin{aligned}
& \text { o } \$ 45,000 \text { - Site survey } \\
& \text { o } \$ 250,000 \text { - 100,000 CFLs } \\
& \text { o } \$ 135,000 \text { - 3-year study } \\
& \text { o } \$ 250,000 \text { - Promotional campaign }
\end{aligned}
$$

Proposed Funding Agent: International Development Association

\subsection{Operation and Maintenance Cost Recovery Plan}

\section{Project 1: Independent Power Plants for Industries}

Post-construction operation and maintenance will be provided by the owner, Oando Gas and Power. After the end of the 5-year Build-Operate-Transfer agreement, LASG will assume ownership of the IPPs and assume all operation and maintenance costs. Since each IPP will have a dedicated customer, revenue from the sale of electricity will cover the costs of operation and maintenance for each owner.

\section{Project 2: Landfill Gas to Energy}

The United Nations Development Programme and the Federal Ministry of Environment are expected to assist with installation and the provision of monetary support for purchasing equipment, while local residents are responsible for the construction of landfill gas energy plants. The Federal Ministry of Environment is also required to train the local community to operate and maintain the plants, as well as send technicians to inspect them every 3 months. For the Makoko community, this project is to be developed alongside project 3, with the exception of it beginning 1 year ahead of the construction of the floating houses for project 3 . 


\section{Macrothink \\ International Journal of Social Science Research \\ ISSN 2327-5510 \\ 2015, Vol. 3, No. 1}

\section{Project 3: Floating Houses with Solar Panels}

The Federal Ministry of Environment and the United Nations Development Programme are responsible for monetary funding and management, while the Heinrich Foundation supports technical research and construction assistance for the local residents to build the houses. Local businesses play an important role in providing materials and solar panels for the houses, while the Makoko Water Front Community promotes the project to raise awareness for the surrounding communities. Local residents are responsible for the main construction, operation and maintenance after training. There will be quarterly inspections from the Federal Ministry of Environment. After an optimization test of the pilot project at Makoko, a similar operational process will be applied to other communities in similar conditions.

\section{Project 4: Solar Panels for Small Businesses}

Businesses are responsible for the purchase and installation of solar panels according to their energy needs. The Lagos State Electricity Board is only expected to provide $40 \%$ subsidies for the cost of solar panels for each business over the course of 5 years. After the 5-year plan, the board can decide to increase, decrease or remain the amount and time length of money subsidized according to the energy needs of businesses.

\section{Project 5: Incandescent Light Bulb Replacement Program}

LSEB will oversee this project, providing the trained labor for the 3-year study and the promotional public awareness campaign. After the end of the campaign in the 5th year, there will be no further operating costs.

\subsection{Timing}

\subsubsection{5-Year Plan (2015-2019)}

The overall goal of this energy plan is to provide adequate and reliable energy coverage for important sectors throughout Lagos, as well as to increase energy efficiency and reduce environmental problems as a byproduct of energy production. Each project is independent in terms of operation and timing, with the exception of projects 2 and 3, which are proposed to be on the same timeline while remaining independent in operation. By combining conventional and alternative energy sources from the abundant existing sources in Lagos, as well as raising awareness for saving energy, Lagos will be able to accomplish this goal over the 5-year time frame and adjust accordingly after that. Moreover, due to the lack of energy coverage and serious inefficiency of current energy production and consumption in Lagos, the above mentioned solutions require immediate funding and research in order to begin construction as soon as possible. 


\begin{tabular}{|c|c|c|c|c|c|}
\hline & Yr 1 & Yr 2 & Yr 3 & Yr 4 & Yr 5 \\
\hline Project 1: & $\begin{array}{l}\text { Construction } \\
\text { of Plant \#1: } \\
\$ 25,000,000\end{array}$ & $\begin{array}{ll}2 & \text { Site } \\
\text { Studies: } & \\
\$ 200,000\end{array}$ & $\begin{array}{l}\text { Construction } \\
\text { of Plant \#2: } \\
\$ 25,000,000\end{array}$ & $\begin{array}{l}\text { Construction } \\
\text { of Plant \#3: } \\
\$ 25,000,000\end{array}$ & \\
\hline Project 2: & $\begin{array}{l}\text { Plant } \\
\text { Construction } \\
\text { in Iwaya: } \\
\$ 39,600\end{array}$ & $\begin{array}{l}\text { Plant } \\
\text { Construction } \\
\text { in Makoko: } \\
\$ 237,600\end{array}$ & $\begin{array}{l}\text { Testing \& } \\
\text { Maintenance: } \\
\$ 50,000\end{array}$ & & \\
\hline Project 3: & $\begin{array}{l}\text { Housing } \\
\text { Construction } \\
\text { in Makoko: } \\
\$ 360,000\end{array}$ & $\begin{array}{l}\text { Testing and } \\
\text { Maintenance: } \\
\$ 50,000\end{array}$ & & $\begin{array}{l}\text { City-wide } \\
\text { Operation: } \\
\$ 720,000\end{array}$ & $\begin{array}{l}\text { City-wide } \\
\text { Operation: } \\
\$ 720,000\end{array}$ \\
\hline Project 4: & $\begin{array}{l}\text { Subsidies } \\
\$ 4,560,000\end{array}$ & $\begin{array}{l}\text { Subsidies } \\
\$ 4,560,000\end{array}$ & $\begin{array}{l}\text { Subsidies } \\
\$ 4,560,000\end{array}$ & $\begin{array}{l}\text { Subsidies } \\
\$ 4,560,000\end{array}$ & $\begin{array}{l}\text { Subsidies } \\
\$ 4,560,000\end{array}$ \\
\hline Project 5: & $\begin{array}{l}\text { Site Survey: } \\
\$ 45,000 \\
\text { Distribution } \\
\text { of CFL } \\
\text { Bulbs: } \\
\$ 295,000\end{array}$ & $\begin{array}{l}\text { Study: } \\
\$ 45,000\end{array}$ & $\begin{array}{l}\text { Study: } \\
\$ 45,000\end{array}$ & $\begin{array}{l}\text { Study: } \\
\$ 45,000\end{array}$ & $\begin{array}{l}\text { Awareness } \\
\text { Campaign: } \\
\$ 250,000\end{array}$ \\
\hline $\begin{array}{l}\text { Total } \\
\text { US\$ }\end{array}$ & $\$ 30,254,600$ & $\$ 5,092,000$ & $\$ 29,655,000$ & $\$ 30,325,000$ & $\$ 5,530,000$ \\
\hline
\end{tabular}

Exhibit 29. Summary of 5-Year Plan

Source: Chapter authors.

\section{WATER}

\subsection{Background}

By 2020, Lagos is expected to be the world's $3^{\text {rd }}$ largest megacity after Beijing and Mumbai (Lagos Water Supply Master Plan, 2010). Thus, a high demand for drinking water must be met to sustain this growing population. This seems feasible considering that Lagos is surrounded by water - in fact, there is an abundance of it. Due to its geographical location, the city receives high amounts of rainfall and has a high groundwater table that feeds into the Lagos Lagoon and the Gulf of Guinea. Because of this, the main source for drinking water is supplied by surface water and ground water resources.

\subsection{Major Problems}

\subsubsection{Demand Gap}

In 2010, the Lagos Water Committee (LWC) produced 210 million gallons per day (MGD) 
with waste water treatment plants utilizing surface and ground water resources (Lagos Water Supply Master Plan, 2010). The water demand of this population stands at 540 MGD, meaning that there was a demand gap of 330 MGD. Considering that only $40 \%$ of the population was served in 2010, the Lagos Water Committee (LWC) responded with a Water Master Plan that identifies the implementation of water infrastructure projects in order to bridge the gap by 2020. This plan states that if the population grows to its projected size and the LWC does not improve the availability of water supply, there will be a 535 MGD demand gap. The installation of these water infrastructure projects will close that gap to 12 MGD. Because the population that typically suffers is those individuals without a permanent structure as a home, it can be expected that the poorest communities will be the ones that experience the remaining lack of water. Additionally, the large demand gap of 2010 was reflected in the typical 500\% mark-up of water prices from vendors who receive water from LWC.

In an attempt to avoid this injustice, projects are recommended in this chapter that should be considered to bridge the 12 MGD that will mainly affect the impoverished slum communities in Lagos.

\subsubsection{Lack of Potable Drinking Water}

With Lagos and other cities of developing countries around the world still experiencing problems with a lack of potable drinking water, the United Nations (UN) considers water supply and basic sanitation a thematic priority area. On July 28, 2010, the United Nations established that access to water and sanitation was a human right that is essential to our lives (United Nations, 2010). The UN requested that international organizations and states provide the tools needed to give this basic human right to all people. With Lagos having an abundance of problems, it is a goal here to extend this right to all residents of the city.

\subsection{Selected Projects}

\subsubsection{Rainwater Harvesting}

Rainwater harvesting has been a technique used for collecting and storing rainwater for many centuries. It involves having a catchment system, mostly the use of rooftops, to catch the rainfall and channel it into a cistern or container on the side of a building. This option is exceptionally beneficial because the water obtained can be stored during dry seasons for later use. These systems have low costs that would benefit poor communities; i.e., cheap materials can be used for the construction; construction methods are taken from local techniques; there are low operation and maintenance costs, as well as reduced storm water runoff, pollution and erosion; and, finally, there is immediate access to safe drinking water.

\subsubsection{Model: Waterbanks - PITCHAfrica}

PITCHAfrica is a U.S. based non-profit organization whose main goal is bringing about social change in Africa. It is funded through ATOPIA Research with a main interest in promoting high-yield rainwater harvesting systems that integrate the community. The Waterbanks schools are a new idea brought about by PITCHAfrica and are designed by team 


\section{Macrothink}

members David Turnbull and Jane Harrison (Milshtein, 2014). These schools are built and designed to collect, store and filter rainwater for the community. The design of these schools includes 4 classrooms, gardens for food cultivation and community spaces available for recreation. These schools are built with a 150,000 liter reservoir harvesting capacity under the courtyard, and an integrated water-filtration system using ceramic water filters. The schools' rooftops each have a total harvesting area of 600 square meters, meaning that there is enough capacity for 300 children to have 4 liters of water per day per year.

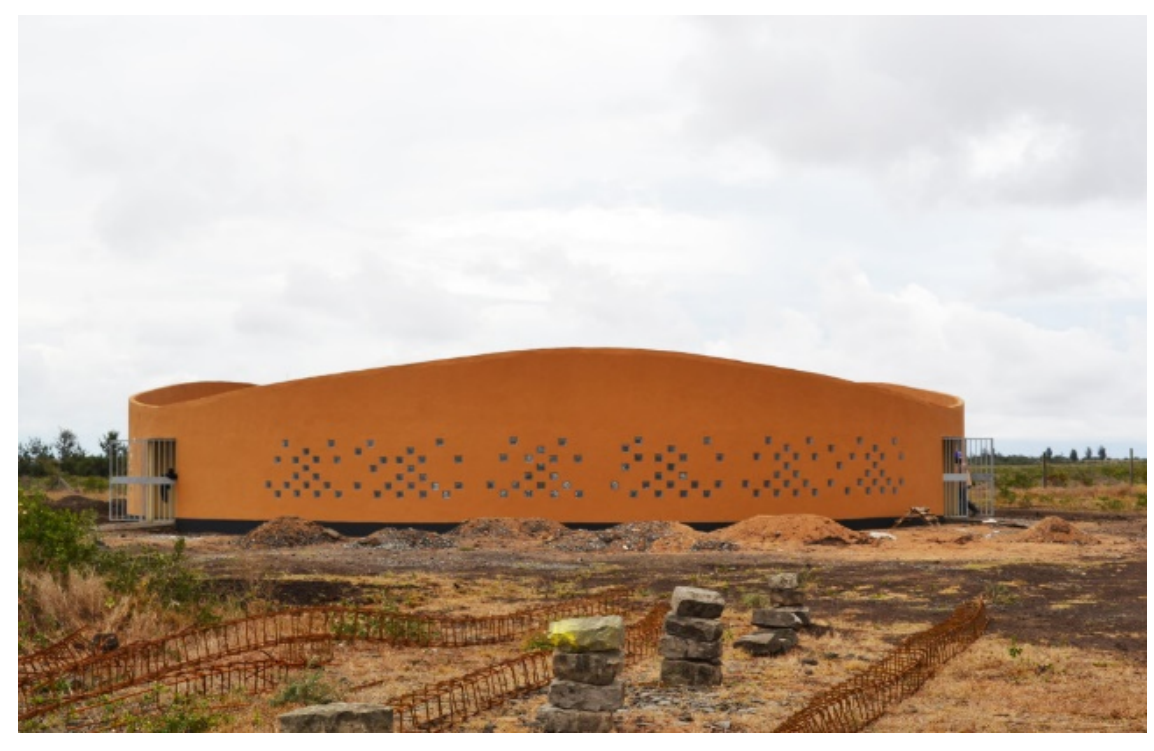

Exhibit 30. Waterbanks School

Source: Waterbanks, 2004.

\subsubsection{Hand Pump Wells: Engage Now Africa}

Hand pump wells offer the opportunity to strategically provide an improved drinking water source to communities in need. While these wells are more often installed in rural communities, individual communities within Lagos at the bottom of the economic pyramid could benefit greatly from this technology if the situation is approached the right way. If the aquifer system can be accessed appropriately, potable water can be produced, and the demand gap among this population can be decreased. The selection of these communities, however, would require a systematic suitability analysis to ensure that the hand pump well will have long-term success. For this reason, it is recommended that a non-profit organization come to Lagos to team up with a local well-installation company to address this problem with the assistance of the funding suggested here. 


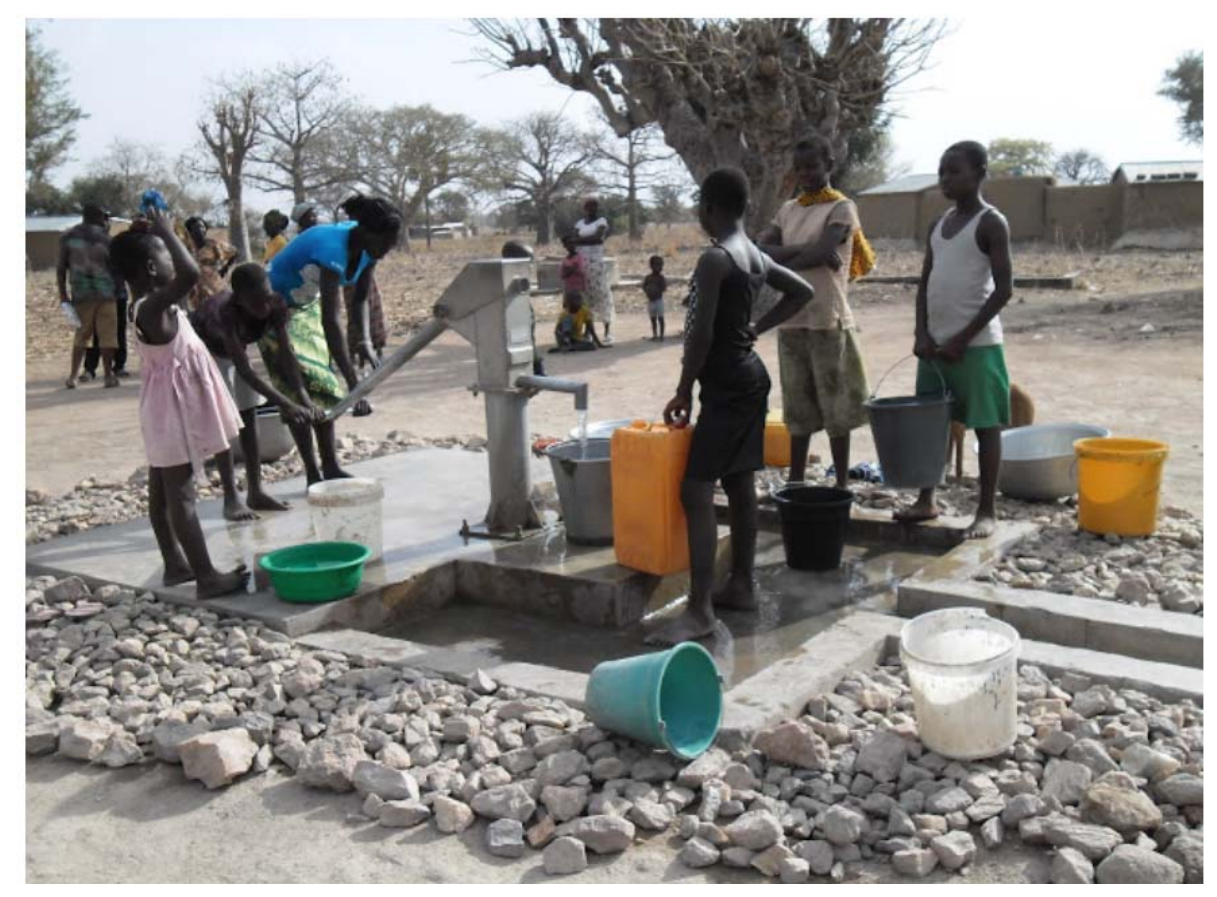

\section{Exhibit 31. Engage Now Africa Hand Pump Well in Ghana}

Source: Engage Now Africa, 2013.

\subsection{Justification of Selected Projects}

\subsubsection{Rainwater Harvesting}

Lagos has 2 rainy seasons that significantly affect its residents. The first season lasts from March to the end of July and the second starts in early September and ends mid-October (Akinloye, 2012). During these periods, Lagos experiences significant flooding that causes damage to its communities, although rainwater catchment systems are able to alleviate some of the problems that occur. Some examples of the problems that could occur are the flooding of homes, and sanitation issues that arise with having flood water mix with open defecation. Another major benefit of these systems is that they can be used on homes, hospitals clinics or schools. Collecting free water will give residents, especially women, relief from work. This is because women spend a grand total of 40 billion work hours a year collecting water! This is a main reason why people are unable to escape poverty. With the help of rainwater catchment systems, women and children will have more time to focus on other activities, such as education and working to support their families.

Specifically choosing to go with the Waterbanks program would be an investment in the community itself. Its main goal as an organization is to provide a high-yield rainwater harvesting system that also provides a curriculum to teach children how to live well in their own communities. The schools will be a teaching tool and community gathering space for residents to use for future education, hopefully decreasing poverty in the area in the long-run. PITCHAfrica's Waterbanks system has low construction costs and is easy to maintain once 
put in place. The system is simple to construct, and the use of local construction techniques and supplies bring down the cost significantly as well. The most beneficial aspect of building the Waterbanks schools in Lagos is that when a clean surface is used, the rainwater is drinkable almost immediately upon falling. Another benefit of the Waterbanks program would be the schools themselves. While providing a clean water supply for the children and local residents, an education to the children in the community will also be provided. Educating the community is how programs like this one will continue to grow, and how the future of the city will be more prosperous.

\subsubsection{Hand Pump Wells}

Engage Now Africa (ENA) is proposed here as the non-profit organization to shape this model. ENA works with a local drilling company to install high quality wells in areas with limited access to potable water. The organization's projects are funded by small donations and large private donors. In 2013, ENA successfully installed 9 wells in Ghana with the leadership of a local drilling company. The hired drilling company is typically well-vetted and trained in order to ensure high-quality well installation practices that result in a high yield and a long life-span. The ultimate long-term success of each well, however, is up to the community. The organization heavily focuses on implementing community caretaker committees to encourage maintenance and communication with the local drilling company for appropriate maintenance and repairs. Water samples are taken throughout the installation and maintenance processes, and tested by a lab hand-picked by ENA to ensure that each well is producing water that is potable. The installed wells typically produce 500-600 gallons per day, but can have a higher yield depending on the hand pump selected and frequency of usage. The selection process of specific sites for well construction is directly dependent on a suitability analysis of conditions that directly affect the resulting yield.

Such an analysis is critical to the selection process of each site because a well that supplies contaminated water or a low yield to an area in desperate need of potable water is not a wise investment. Wells typically found in Lagos are of low quality and are not capable of maintaining their high yield or potable quality for a variety of reasons (Longe, 2011). Factors that contribute to this limited success include the complex structure of Lagos' aquifer system and vulnerability to contamination by industrial and human/animal effluents. As a result, the suitability analysis is directly aimed at avoiding these complications and locating communities that could benefit most from these wells. Thus, 6 slums are identified as the communities receiving wells: Ijora/Badia, Oworonshode, Ilaje/Bariga, Shomolu, Mushin, and Makoko, and are used in the model, which follows.

\subsubsection{Model}

The goal in this section of the paper is to maintain ENA's working model while applying it to the urban environment. This is done by expanding the working structure of ENA to establish a more dependent relationship with a local construction company and create 6 working subgroups that will work closely with the selected communities. This requires ENA and a local drilling company to embark on a long-term joint venture. To guide this establishment, a local well-drilling company is chosen, a hand pump selected, installation practices adopted, 
and the engagement of care-taker committees undertaken.

The local Sannati Group of Companies was identified as a prime candidate to provide construction and continued maintenance to these wells. This company is based in Lagos and manages smaller branches. Thus, it has high potential for further expansion. The company has thorough experience with well construction and offers a wide selection of hand pumps. In consideration of the complex aquifer system, the common, durable, user friendly and consistent Afridev Handpump was selected as the ideal pump (Chave, P. et al., 2011).

ENA typically trains the construction teams to ensure a high quality installation and high yield of each well. Thus, ENA should send in trainers that focus on implementing critical construction techniques, like well logging prior to casing and screening of wells. In addition, the individual who will engage the communities on a personal level should be trained and sent in by ENA, as this role is critical to the empowerment of the community and ultimate success of each project. These committees will be responsible for communicating with the respective subgroup for required maintenance and repairs. The committee will also preserve a wellhead protection zone that is "directly adjacent to the site of the well to prevent rapid ingress of contaminants or damage to the wellhead (Ibid.)." To ensure this wellhead protection zone, there can be no open defecation or waste that could seep into the wellhead.

Overall, the joint venture will focus on hiring and training local skilled workers to construct the wells as part of a subgroup; 6 subgroups will be created and will each focus on a slum. They will pin-point where the well will be drilled, engage the community to take part in the project, establish a caretaker committee for each well, and test the water quality and production of each well. These subgroups will each drill 9 wells for 3 years, resulting in a total of 27 wells by each subgroup and a total of 162 wells from 2018-2020. This will require thorough communication between ENA and Sannati, as well as oversight and support, throughout the 2 years of organization and 3years of construction.

\subsection{Operation and Maintenance Plan}

\subsubsection{Rainwater Harvesting}

Operation and maintenance (O\&M) of these schools and their filtration systems will be the responsibility of the Lagos State Government. PITCHAfrica and its team will establish a training program that will then be given to the Lagos State Government for future use. The community liaison and project management team for the Waterbanks model is The Zeitz Foundation for Intercultural Ecosphere Safety. Its job is to integrate the community into projects put in place to ensure their success. It will also be the foundation's job to keep the Lagos State Government up to date with the project in order for it to take over the schools and provide the funding for upkeep. The government will also be in charge of hiring trained operations workers to keep up with the O\&M of the schools and their systems.

\subsubsection{Hand Pump Wells}

The operation and maintenance of this plan requires continued operations by ENA and Sannati. This includes continued training and support to subgroups and its workers, 
communication with caretaker committees, and testing of water quality and production of wells after 2020. The subgroups will be responsible for all necessary well repairs. This requires that ENA continue training protocols to ensure that appropriate techniques are being used to identify and address hardware issues. Continued communication between caretaker committees and subgroups must be conserved to ensure that the wells are repaired when broken. To make sure that the wells are working appropriately and that the community is thoroughly engaged with the project, each subgroup will visit each well annually for 4 years after construction to test water quality and production. There will also be a general cleanliness analysis of the wellhead protection zone to check that the caretaker committees are protecting the wellhead from contamination. There are further concerns for project implementation that should be noted at this point.

The goal is for the wells to have a long life span. However, the heavy initial usage that these wells may experience could be damaging and result in necessary immediate repairs. This may be more of a concern for the wells installed the first year. Parts of the well could also be stolen by someone not dependent on the water supply from that specific well. Unsanitary practices in the wellhead protection zone could easily result in wellhead contamination and further jeopardize the quality of the water supply. It is essential for the caretaker committee to be engaged with the community to prevent misuse, theft and contamination that could easily halt water production. Thorough communication and transparency with the corresponding subgroup is also vital to ensure the engagement of the surrounding community.

\subsection{Capital Costs}

\subsubsection{Rainwater Harvesting}

PITCHAfrica has launched WATERBANKS OS, an operating manual available online, on request starting January 2015. With the cost of the schools being the same as the average rural school in Africa, capital costs are minimal. The cost of one of these schools is $\$ 60,000$ (Milshtein, 2014). There will be a total of 4 schools built from 2016 to 2019 for a total of $\$ 240,000$ in initial costs, with operation and maintenance costs covered by government expenditures related to education. The initial costs of the schools are completely funded by the Guernsey Overseas Aid Fund, leaving minimal capital costs for the government to provide.

\subsubsection{Hand Pump Wells}

Once the joint venture of ENA and Sannati proposed here is well established, it will be responsible for expansion, construction and repair costs, as well as continual water quality and recovery tests. The specific costs are listed below in Exhibit 32. 


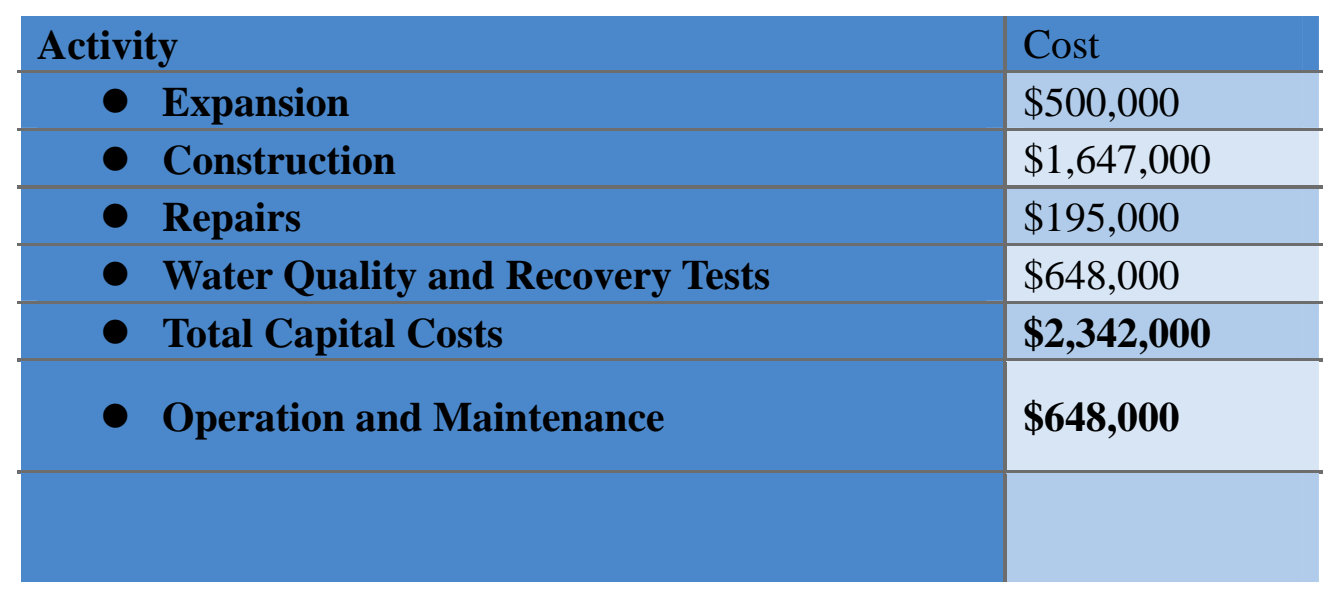

Exhibit 32. Cost Breakdown

Source: Chapter authors.

Specifically, the expansion cost considers hiring immediate staff and obtaining a work space, training professionals, and appropriate permits. The construction cost accounts for sinking 162 wells at a cost of \$8,000 each, based on the construction of a 50 meter well in Villa El Carmen, Nicaragua, which has a geology and aquifer system similar to Lagos, by CrossWay International in 2012 (Chollar, 2012). A 15\% contingency was added to the budget in case further material and energy costs are necessary to complete the wells. The repairs cost is based on the assumption that each well's repairs over 30 years will not exceed $\$ 1,200$, the cost of the actual hand pump. The water quality and recovery tests item is estimated based on the amount of tests that each well will receive for 30 years. Each well will be tested annually for 5 years and once every 5 years after that for 30 years - a total of 10 times, each time costing around $\$ 400$. It should be noted that the O\&M cost does not include costs for employees of ENA and Sannati, which includes subgroup staff, as well as the training of professionals and other non-profit employees. This was not estimated as each non-profit establishes its own structure for compensation of its employees, varying by skill and degree. It is also expected that some of these positions will be filled by interns and volunteers. Thus, the total capital cost figure to be financed by ENA's combination of small donations and large private donors is $\$ 2,342,000$, and the joint venture of ENA and Sannati will assume the O\&M cost of $\$ 648,000$ once construction is completed.

\subsection{Timeline}

\subsubsection{Rainwater Harvesting}

The first year will consists of studies and site selection for 4 Waterbanks schools to be built in a 5 year time period. Sites will be evaluated and accessed for feasibility and need for new schools in the area. The slum areas to be focused on are Iwaya, Sari Iganmu/Orile, Amukoko and Ajegunle. The timeline for the construction of a Waterbanks school is 1 calendar year. In 2015, sites will be selected and donors will be secured. Starting in 2016, one Waterbanks school will be constructed per year for the next 4 years of the 30 year master plan. After the 
construction of a school, it will be handed over to the Lagos State Government and operated and maintained from there.

\subsubsection{Hand Pump Wells}

\subsubsection{The 5-Year Plan}

The 5-Year Plan identifies specific actions that must take place starting in 2015 to construct 162 wells by 2020, as shown in Exhibit 33 below.

\begin{tabular}{|c|c|c|c|c|c|}
\hline Year & $\begin{array}{l}\text { Year 1- } \\
2015\end{array}$ & $\begin{array}{l}\text { Year 2- } \\
2016\end{array}$ & $\begin{array}{l}\text { Year 3- } \\
2017\end{array}$ & $\begin{array}{l}\text { Year } \\
4-2018\end{array}$ & $\begin{array}{l}\text { Year } \\
5-2019\end{array}$ \\
\hline \multirow{5}{*}{ Activity } & \multirow{2}{*}{$\begin{array}{l}\text { Organize } \\
\text { ENA and } \\
\text { Sannati Joint } \\
\text { Venture }\end{array}$} & $\begin{array}{l}\text { Subgroups train } \\
\text { and plan for } 9 \\
\text { wells for Year } 3\end{array}$ & $\begin{array}{l}\text { Subgroups } \\
\text { drill } 9 \text { wells }\end{array}$ & $\begin{array}{l}\text { Subgroups } \\
\text { drill } 9 \\
\text { wells }\end{array}$ & $\begin{array}{l}\text { Subgroups } \\
\text { drill } 9 \\
\text { wells }\end{array}$ \\
\hline & & $\begin{array}{l}\text { ENA \& } \\
\text { subgroups } \\
\text { pin-point sites }\end{array}$ & $\begin{array}{l}\text { Subgroups } \\
\text { plan for } 9 \\
\text { wells for } \\
\text { Year } 4\end{array}$ & $\begin{array}{l}\text { Subgroups } \\
\text { plan for } 9 \\
\text { wells }\end{array}$ & $\begin{array}{l}\text { Subgroups } \\
\text { visit Year } 3 \\
\text { \& Year } 4 \\
\text { wells }\end{array}$ \\
\hline & $\begin{array}{l}\text { Create } 6 \\
\text { subgroups }\end{array}$ & $\begin{array}{l}\text { Subgroups } \\
\text { gather } \\
\text { community } \\
\text { support }\end{array}$ & $\begin{array}{l}\text { Perform } \\
\text { repairs, as } \\
\text { requested }\end{array}$ & $\begin{array}{l}\text { Subgroups } \\
\text { visit Year } \\
3 \text { wells }\end{array}$ & \\
\hline & $\begin{array}{l}\text { Allocate } \\
\text { professional } \\
\text { trainers }\end{array}$ & $\begin{array}{l}\text { Acquire stable } \\
\text { material sources }\end{array}$ & & & \\
\hline & $\begin{array}{l}\text { Subgroups } \\
\text { begin } \\
\text { training }\end{array}$ & $\begin{array}{l}\text { Find and secure } \\
\text { stable energy } \\
\text { source }\end{array}$ & & & \\
\hline
\end{tabular}

Exhibit 33. 5-Year Plan by Activity

Source: Chapter authors.

Although construction ends in 2019, activities must continue to ensure that the wells are receiving appropriate attention. This includes visiting 2017 wells annually for another 3 years, visiting 2018 wells annually for another 4 years, visiting 2019 wells annually for another 5 years, and visiting all wells every 5 years after annual check-ups are completed for 25 years. It is necessary to begin planning and organizational activities immediately, allowing for 2 years of implementation before construction is scheduled to begin in 2017 to meet the 2020 deadline. 


\section{FINANCE}

\subsection{Urban Development Challenges for Developing Countries}

Developing countries are in a constant struggle with constraints to development. These consist of high economic poverty, hunger, high mortality rates, unsafe water supplies, poor educational systems, corrupt governments, war and poor sanitation. Moving past these constraints is difficult and is only possible when putting in place consistent, long-term policies. Consequently, the World Bank offers, "6 areas of policy to improve chances of development: investment in education and health, increasing productivity of small farms, improving infrastructure (for example, roads), developing an industrial policy to promote manufacturing, promoting democracy and human rights, and ensuring environmental protection (Globalization, 2014).” The World Bank believes developing countries need to pursue these 6 areas of policy in order to promote outside financing and investment to promote growth. Developing countries need more than just government support; they need direct foreign investment and outside loans. Although it is a challenge to attract foreign investment, it is essential to promote community growth and health in the area. The finance sector thus plays a major role in developing countries.

\subsection{Financing Urban Environmental Management in Lagos}

The financial sector has long been recognized as playing a crucial role in the economic development of a country, but the global financial system has experienced rapid growth and substantial structural change during the last ten years leading to globalization of financial markets. The integration of financial markets has increased the rapid flow of capital across borders as well as magnified the contagious effects of a financial crisis with wide implications for transmission of financial policies on the domestic economy and internationally, which is evident in Nigeria’s financial system (Ogujiuba \& Obiechina, 2011).

Nigeria is currently experiencing rapid economic growth as a mixed economy with an emerging market. Developed countries are heavily investing in it, with the United States being the largest investor. Previously, economic development had been hindered by years of military rule, corruption and mismanagement. The restoration of democracy, and subsequent economic reforms, has successfully put Nigeria back on track towards achieving its full economic potential. Nigeria is expected to have the highest average GDP growth in the world between 2010 and 2050, although this might be constrained if oil prices remain at the low level of early 2015. Nevertheless, strong economic conditions have led to a spillover effect on fast-paced urbanization in the country. High migration to cities along with population expansion is putting intense pressure on the urban environments in Nigeria (Asomani-Boateng, 2013).

This is especially true of Lagos, which is Nigeria's economic focal point, and generates a significant portion of the country's GDP. Most commercial and financial business is carried out in its central business district. This is also where most of the country's commercial banks, financial institutions, and major corporations are headquartered, thus making it the ideal location for large investments from private and public sectors alike. However, its growth and 
expansion have overburdened the existing urban management systems. Hence the 5-year plan that has been prepared in this paper focuses on such issues with a practical approach and implementable strategies. One of the essentials in implementing such a plan, of course, is finance. It is critical that enough funding is available for every project to be completed within the 5 year extent of the plan. Therefore, the finance group had a crucial role to play, that is, to ensure the availability of funding for all projects proposed by the 6 other sectoral working groups (i.e., poverty alleviation, industry, sewage and solid waste, transportation, energy and water) comprising the project team.

\subsection{Work Plan of the Finance Group}

The objective here was to identify potential sources of funding, calculate the amounts that could be acquired from each of them, and then allocate those funds to each sectoral working group. Each of the 6 sectoral groups was requested to prioritize its projects based on need, urgency and significance of the implementation of a particular project. The teams were allowed to develop their own financing strategies if they wished. The finance team created a database of funding that would be available to each working group for each of their projects over a period of 5 years (2015-2019). The funding would or would not be utilized by the sectoral working groups depending on whether or not they already had a funding strategy in place for any of their projects.

\subsection{Methodology}

The process was divided into 3 phases. The first phase involved exploring potential sources and amounts of funding that could be expected from each source for any environmental sector. The second phase involved interaction with other groups to understand the significance and priorities of their proposed projects, to help them determine which of these projects would be adopted and in what order of priority they would be implemented. The third phase involved creating a database of available funding by organizing and totaling the funds projected from the identified sources and then distributing them among the groups' projects.

\subsection{Identification of Sources of Funding}

The first step was research to find the right sources of funding. After analyzing similar case studies of urban development in other developing countries, it was determined that there are 2 major players in funding urban environmental projects that ensure efficient implementation: foreign aid and foreign direct investment. However, it was also necessary to involve the government in finance, because the government is normally the only authority that is constitutionally obligated to manage the urban environment in a country.

\subsection{Research Process for Foreign Aid Opportunities}

In order to ensure that appropriate nations would be solicited for project funds, it was first determined what exactly constituted foreign aid. The primary source of foreign aid is Official Development Assistance (ODA). It is defined as development assistance in areas of need such as food aid, emergency relief, peacekeeping, infrastructure improvement, poverty alleviation, etc. (OECD, 2011). It was then determined which countries and international organizations 
contributed the most foreign aid to Nigeria in the past 5 years. Exhibit 34 lists the top donor organizations and countries with their respective foreign aid provided to Nigeria in 2012.

\begin{tabular}{|l|l|l|l|}
\hline Sr. No. & Source & Aid (US\$ Million) & \% Contribution \\
\hline 1 & IDA & 479.32 & $23.71 \%$ \\
\hline 2 & United States & 419.11 & $20.73 \%$ \\
\hline 3 & United Kingdom & 312.7 & $15.47 \%$ \\
\hline 4 & Global Fund & 213.54 & $10.56 \%$ \\
\hline 5 & EU Institutions & 121.61 & $6.02 \%$ \\
\hline 6 & Bill \& Melinda & 109.19 & $5.40 \%$ \\
\hline 7 & Gates Foundation & 53.56 & $2.65 \%$ \\
\hline 8 & UNICEF & 48.12 & $2.38 \%$ \\
\hline 9 & Japan & 45.31 & $2.24 \%$ \\
\hline 10 & AfDF & 44.2 & $2.19 \%$ \\
\hline & GAVI & 1846.66 & $91.35 \%$ \\
\hline
\end{tabular}

Exhibit 34. ODA Assistance to Nigeria (2012) Source: Aidflows, 2014.

Next, it was necessary to project the amounts of foreign aid that could be received over next 5 years, and the aid flows of countries from the past 5 years were used to determine the yearly aid flow to Nigeria. The trend was determined by linear extrapolation assuming a constant growth rate. Exhibit 35 shows the expected yearly aid to Nigeria using this technique:

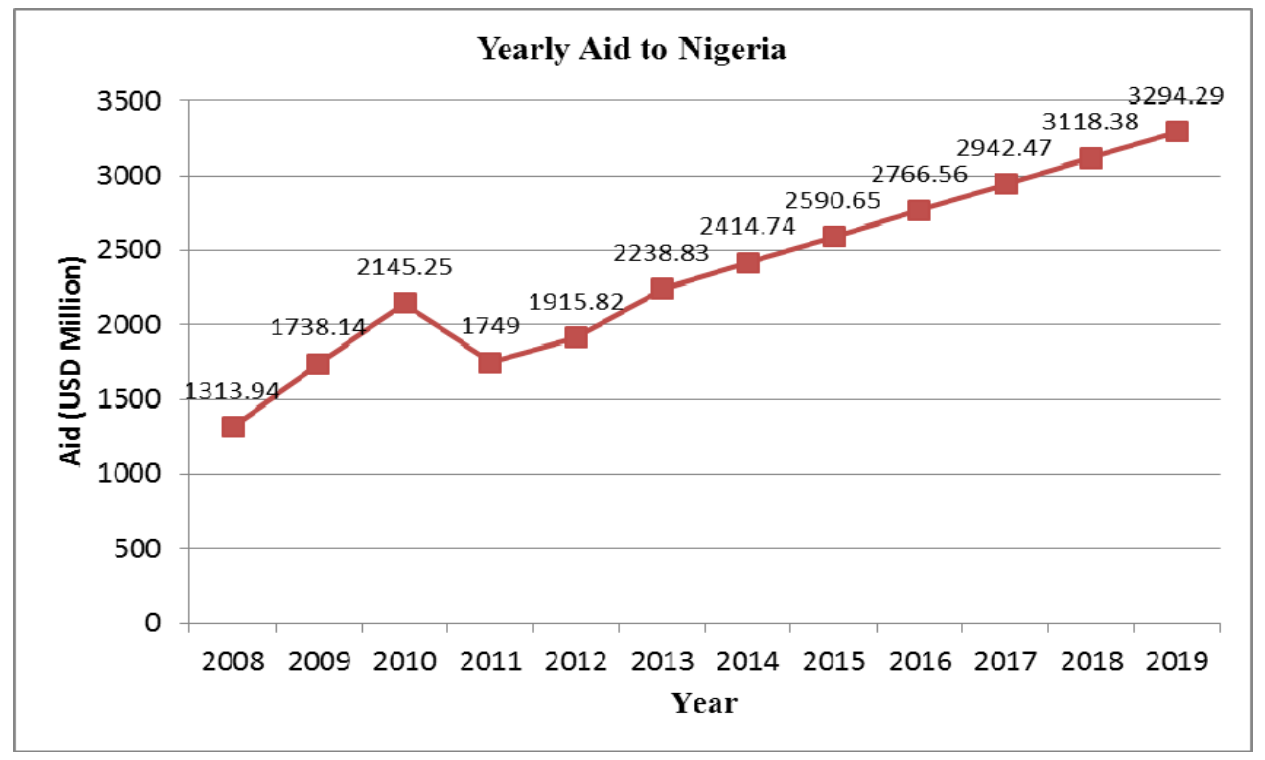

Exhibit 35. Projected Foreign Aid for the Plan

Source: Chapter authors. 
Finally, based on these projections, the expected aid over next 5 years was divided among the donor countries using the same percentage distribution as in year 2012 as is presented in Exhibit 36 below.

\begin{tabular}{|c|c|c|c|c|c|c|c|c|}
\hline \multirow[t]{2}{*}{ Source } & \multicolumn{7}{|c|}{ US\$ million } & \multirow{2}{*}{$\begin{array}{l}\% \\
\text { Contri-b } \\
\text { ution }\end{array}$} \\
\hline & 2014 & 2015 & 2016 & 2017 & 2018 & 2019 & $\begin{array}{l}\text { Total } \\
(2015-2019)\end{array}$ & \\
\hline IDA & 572.57 & 614.28 & 655.99 & 697.70 & 739.41 & 781.12 & 3488.51 & 23.71 \\
\hline $\begin{array}{l}\text { United } \\
\text { States }\end{array}$ & 500.65 & 537.12 & 573.59 & 610.06 & 646.53 & 683.00 & 3050.30 & 20.73 \\
\hline $\begin{array}{l}\text { United } \\
\text { Kingdom }\end{array}$ & 373.53 & 400.75 & 427.96 & 455.17 & 482.38 & 509.59 & 2275.84 & 15.47 \\
\hline $\begin{array}{l}\text { Global } \\
\text { Fund }\end{array}$ & 255.08 & 273.67 & 292.25 & 310.83 & 329.41 & 348.00 & 1554.15 & 10.56 \\
\hline $\begin{array}{l}\text { EU } \\
\text { Institutions }\end{array}$ & 145.27 & 155.85 & 166.43 & 177.02 & 187.60 & 198.18 & 885.08 & 6.02 \\
\hline $\begin{array}{l}\text { Gates } \\
\text { Foundation }\end{array}$ & 130.43 & 139.93 & 149.44 & 158.94 & 168.44 & 177.94 & 794.69 & 5.40 \\
\hline UNICEF & 63.98 & 68.64 & 73.30 & 77.96 & 82.62 & 87.28 & 389.81 & 2.65 \\
\hline Japan & 57.48 & 61.67 & 65.86 & 70.04 & 74.23 & 78.42 & 350.22 & 2.38 \\
\hline AfDF & 54.12 & 58.07 & 62.01 & 65.95 & 69.90 & 73.84 & 329.77 & 2.24 \\
\hline GAVI & 52.80 & 56.65 & 60.49 & 64.34 & 68.18 & 72.03 & 321.69 & 2.19 \\
\hline
\end{tabular}

Exhibit 36. Top Donors of Foreign Aid to Nigeria

Source: Aidflows, 2014.

The next challenge was to investigate the sectors to which each country contributed aid. This was crucial because only then could the finance group assess which sectoral group could receive funding from a particular country. For this purpose, an in-depth exploration of the data released by the funding agencies of donor countries or organizations was undertaken. Each donor country had its own sectoral distribution of aid. One country offered more aid to one particular sector than to other sectors, or sometimes only to a select few sectors (OECD, 2011; USAID, 2014; Nigeria, 2014).

In addition, to estimate the aid that would be available for Lagos in the urban environmental sectors of this study, it was necessary to make an assumption for each donor country or agency of the percentage that would be received by Lagos out of the total amount of aid received by Nigeria. In order to reach that assumption, the population proportion of Lagos State out of the total population of Nigeria was taken into consideration. According to census data, the current population of Lagos comprises about $6.4 \%$ of the total population of Nigeria. Therefore, it was assumed that Lagos would receive $6.4 \%$ of the total foreign aid for Nigeria 
(Government, 2014). Thus, a database was created for each donor country that contained the sectoral percentage distribution of the projected aid figures from that country. As an example, Exhibit 37 below shows the data generated for sectoral foreign aid to be received by Lagos from one donor country (US) and one donor organization (World Bank). It is distributed over the 5 years of the plan period (USAID, 2014; Lagos, 2014).

\begin{tabular}{|l|l|l|l|l|l|l|}
\hline USAID & $\mathbf{2 0 1 5}$ & $\mathbf{2 0 1 6}$ & $\mathbf{2 0 1 7}$ & $\mathbf{2 0 1 8}$ & $\mathbf{2 0 1 9}$ & Total \\
\hline Energy & $1,375,021$ & $1,468,388$ & $1,561,754$ & $1,655,121$ & $1,748,487$ & $7,808,772$ \\
\hline Industry & 687,511 & 734,194 & 780,877 & 827,560 & 874,244 & $3,904,386$ \\
\hline $\begin{array}{l}\text { Poverty } \\
\text { Alleviation }\end{array}$ & $1,031,266$ & $1,101,291$ & $1,171,316$ & $1,241,341$ & $1,311,366$ & $5,856,579$ \\
\hline $\begin{array}{l}\text { Water } \\
\text { Supply }\end{array}$ & $8,593,883$ & $9,177,424$ & $9,760,965$ & $10,344,506$ & $10,928,046$ & $48,804,824$ \\
\hline Transport & 343,755 & 367,097 & 390,439 & 413,780 & 437,122 & $1,952,193$ \\
\hline Sanitation & $8,593,883$ & $9,177,424$ & $9,760,965$ & $10,344,506$ & $10,928,046$ & $48,804,824$ \\
\hline
\end{tabular}

\begin{tabular}{|l|l|l|l|l|l|l|}
\hline World Bank & $\mathbf{2 0 1 5}$ & $\mathbf{2 0 1 6}$ & $\mathbf{2 0 1 7}$ & $\mathbf{2 0 1 8}$ & $\mathbf{2 0 1 9}$ & Total \\
\hline Energy & $2,359,040$ & $2,519,040$ & $2,679,040$ & $2,839,040$ & $2,999,680$ & $13,395,840$ \\
\hline Industry & $1,612,160$ & $1,721,600$ & $1,831,040$ & $1,940,480$ & $2,049,920$ & $9,155,200$ \\
\hline $\begin{array}{l}\text { Poverty } \\
\text { Alleviation }\end{array}$ & $3,184,640$ & $3,400,960$ & $3,616,640$ & $3,832,960$ & $4,049,280$ & $18,084,480$ \\
\hline Water Supply & $1,965,440$ & $2,099,200$ & $2,232,960$ & $2,366,080$ & $2,499,840$ & $11,163,520$ \\
\hline Transport & $4,560,640$ & $4,870,400$ & $5,179,520$ & $5,489,280$ & $5,799,040$ & $25,898,880$ \\
\hline Sanitation & $1,965,440$ & $2,099,200$ & $2,232,960$ & $2,366,080$ & $2,499,840$ & $11,163,520$ \\
\hline
\end{tabular}

Exhibit 37. Estimated Yearly Aid from Foreign Agencies (US\$)

Source: Chapter authors.

This database served as a reference for the entire project team regarding potential foreign aid sources and how much funding might be available from these sources.

\subsection{Process to Determine Funding Requirements}

A grant application was provided to each group to identify the appropriate funds needed and the estimated completion time for each. The purpose of the application was to prioritize all the projects by sectoral group and allow the financial group to determine the money available to all of the urban environmental projects. In the application, it was required to explain the benefits for each of the projects. In addition, each sectoral working group listed on the application the possible funds it anticipated receiving without the need of the financial group. Furthermore, each team was required to identify case studies that had been implemented elsewhere in Nigeria or in other developing countries. Finally, because the state budget and 
foreign aid agencies show the allocation of funds though differently defined sectors than in this study, each group was further required to analyze how their projects would fit in with these sectors, which would allow them to possibly receive more financial assistance. In essence, the grant application prioritized every project proposed by each of the sectorial groups to help provide financing for all projects. Exhibit 38 shows the annual project costs.

\begin{tabular}{|c|c|c|c|c|c|c|}
\hline Group & Project & Year 1 & Year 2 & Year 3 & Year 4 & Year 5 \\
\hline Energy & $\begin{array}{l}\text { Independent Power } \\
\text { Plants }\end{array}$ & 25.5 & .2 & 25.5 & 25.5 & 0 \\
\hline Energy & $\begin{array}{l}\text { Landfill Gas Energy } \\
\text { and Solar Panels }\end{array}$ & .3996 & .286 & .05 & .72 & .72 \\
\hline Energy & $\begin{array}{l}\text { Solar Panels for } \\
\text { Small Business }\end{array}$ & 4.56 & 4.56 & 4.56 & 4.56 & 4.56 \\
\hline Energy & $\begin{array}{l}\text { Promotion of Energy } \\
\text { Efficient Lighting }\end{array}$ & .295 & .045 & .045 & .0 .45 & .25 \\
\hline Industry & $\begin{array}{l}\text { Update } \\
\text { Pharmaceutical } \\
\text { Industry }\end{array}$ & 12 & 0 & 0 & 0 & 0 \\
\hline Industry & $\begin{array}{l}\text { Build Petrochemical } \\
\text { Industry }\end{array}$ & 280 & 280 & 140 & 0 & 0 \\
\hline Industry & $\begin{array}{l}\text { Agriculture-Construct } \\
\text { Palm Oil Processing } \\
\text { Plant }\end{array}$ & 20 & 60 & 40 & 10 & 0 \\
\hline Industry & \begin{tabular}{|l|} 
Job Training and \\
Trade Skill Education \\
\end{tabular} & 1.5 & 1.5 & 1.5 & 1.5 & 1.5 \\
\hline $\begin{array}{l}\text { Poverty } \\
\text { Alleviation }\end{array}$ & Land Titling Program & 2 & .75 & .75 & .75 & .75 \\
\hline $\begin{array}{l}\text { Poverty } \\
\text { Alleviation }\end{array}$ & Tiny Abod Homes & 20 & 20 & 20 & 20 & 15 \\
\hline $\begin{array}{l}\text { Poverty } \\
\text { Alleviation }\end{array}$ & $\begin{array}{l}\text { Build Change } \\
\text { Resilient Structures }\end{array}$ & 1 & .25 & .25 & .25 & .25 \\
\hline $\begin{array}{l}\text { Poverty } \\
\text { Alleviation }\end{array}$ & $\begin{array}{l}\text { Microfinance } \\
\text { Institution }\end{array}$ & 3 & 2 & 1 & 1 & 1 \\
\hline $\begin{array}{l}\text { Sewage and } \\
\text { Waste }\end{array}$ & $\begin{array}{l}\text { Construct } 6 \\
\text { Communal Waste } \\
\text { Collection Facilities }\end{array}$ & .093 & .093 & .093 & .093 & .187 \\
\hline $\begin{array}{l}\text { Sewage and } \\
\text { Waste }\end{array}$ & \begin{tabular}{|l|} 
Expand Local \\
Recycling Collection \\
Services
\end{tabular} & .0148 & .006 & .0148 & .006 & .008 \\
\hline $\begin{array}{l}\text { Sewage and } \\
\text { Waste }\end{array}$ & $\begin{array}{l}\text { Public Awareness, } \\
\text { Education, and } \\
\text { Acceptance }\end{array}$ & .01 & .01 & .01 & .01 & .02 \\
\hline
\end{tabular}




\begin{tabular}{|l|l|l|l|l|l|l|}
\hline & Campaigns & & & & & \\
\hline Transportation & $\begin{array}{l}\text { Ferry Boats and } \\
\text { Stations }\end{array}$ & .49 & .34 & .45 & .17 & 0 \\
\hline Transportation & Bus Stops & .002 & .002 & .002 & 0 & 0 \\
\hline Water & $\begin{array}{l}\text { Rainwater } \\
\text { Harvesting-Schools }\end{array}$ & 0 & .06 & .06 & .060 & .06 \\
\hline Water & Hand Pump Wells & .25 & .25 & .624 & .624 & 624 \\
\hline
\end{tabular}

Exhibit 38. Yearly Project Costs (US\$ million)

Source: Compiled by chapter authors.

Finally, the analysis of the grant applications helped establish the amount of funding that was actually required by the sectoral groups. The teams had formed their own strategies to finance their projects, which are shown by the amounts presented in the fourth column of Exhibit 39 which follows.

\begin{tabular}{|l|l|l|l|l|}
\hline Project & Group & Project Cost & $\begin{array}{l}\text { Funding from } \\
\text { the Group } \\
\text { Strategies }\end{array}$ & $\begin{array}{l}\text { Additional } \\
\text { Funding } \\
\text { Needed }\end{array}$ \\
\hline $\begin{array}{l}\text { Independent Power } \\
\text { Plants }\end{array}$ & Energy & $76,700,000$ & $76,700,000$ & 0 \\
\hline $\begin{array}{l}\text { Landfill Gas Energy \& } \\
\text { Solar Panels }\end{array}$ & Energy & $2,127,200$ & $1,000,000$ & $1,127,200$ \\
\hline $\begin{array}{l}\text { Solar Panels for Small } \\
\text { Businesses }\end{array}$ & Energy & $22,800,000$ & 0 & $22,800,000$ \\
\hline $\begin{array}{l}\text { Promotion of Energy } \\
\text { Efficient Lighting }\end{array}$ & Energy & 680,000 & 0 & 680,000 \\
\hline $\begin{array}{l}\text { Rainwater } \\
\text { Harvesting-School }\end{array}$ & Water & 300,000 & 60,000 & 240,000 \\
\hline Hand Pump Wells & Water & $2,371,100$ & 0 & $2,371,100$ \\
\hline Land Titling Program & $\begin{array}{l}\text { Poverty } \\
\text { Alleviation }\end{array}$ & $5,000,000$ & $20,000,000$ & 0 \\
\hline Tiny Abod Homes & $\begin{array}{l}\text { Poverty } \\
\text { Alleviation }\end{array}$ & $95,000,000$ & $90,000,000$ & $5,000,000$ \\
\hline $\begin{array}{l}\text { Build Change Resilient } \\
\text { Structures }\end{array}$ & $\begin{array}{l}\text { Poverty } \\
\text { Alleviation }\end{array}$ & $2,000,000$ & 82,000 & $1,918,000$ \\
\hline Microfinance Institution & $\begin{array}{l}\text { Poverty } \\
\text { Alleviation }\end{array}$ & $8,000,000$ & $15,000,000$ & 0 \\
\hline $\begin{array}{l}\text { Construct 6 Communal } \\
\text { Waste Collection }\end{array}$ & $\begin{array}{l}\text { Sewage and } \\
\text { Solid Waste }\end{array}$ & 560,000 & 0 & 560,000 \\
\hline
\end{tabular}




\section{Macrothink}

\begin{tabular}{|l|l|l|l|l|}
\hline Facilities & & & & \\
\hline $\begin{array}{l}\text { Expand Local Recycling } \\
\text { Collection Services }\end{array}$ & $\begin{array}{l}\text { Sewage and } \\
\text { Solid Waste }\end{array}$ & 50,000 & 0 & 50,000 \\
\hline $\begin{array}{l}\text { Public Awareness, } \\
\text { Education \& Acceptance } \\
\text { Campaigns }\end{array}$ & $\begin{array}{l}\text { Sewage and } \\
\text { Solid Waste }\end{array}$ & 60,000 & 0 & 60,000 \\
\hline Ferry Boats \& Stations & Transportation & $1,040,000$ & 400,000 & 640,000 \\
\hline Bus Stops & Transportation & 7,000 & 0 & 7,000 \\
\hline $\begin{array}{l}\text { Update Pharmaceutical } \\
\text { Technology }\end{array}$ & Industry & $12,000,000$ & $11,271,000$ & 729,000 \\
\hline $\begin{array}{l}\text { Build Petrochemical } \\
\text { Plant }\end{array}$ & Industry & $700,000,000$ & $9,042,000,000$ & 0 \\
\hline $\begin{array}{l}\text { Agriculture-Construct } \\
\text { Palm Process }\end{array}$ & Industry & $130,000,000$ & $1,000,000,000$ & $\$ 0$ \\
\hline $\begin{array}{l}\text { Job Training \& Trade } \\
\text { Skills Education }\end{array}$ & Industry & $10,000,000$ & $1,000,000,000$ & 0 \\
\hline
\end{tabular}

Exhibit 39. Project Funding Requirements (US\$)

Source: Compiled by chapter authors.

\subsection{Availability of FDI}

Foreign direct investment (FDI) is described as an investment made by a company or entity based in one country, into a company or entity based in another country (Trading Economics, 2014). The top contributing countries are the United States, South Africa, UK, India, and France (OECD, 2011). The largest sectors for investment in Lagos are technology, media and telecommunications, retail consumer products, business services, financial services, coal, oil and natural gas, real estate, hospitality, and construction (Ibid.). However, not every country invests in every sector. These data were critical to identifying the potential private sources of funding. Exhibit 40 below shows the amount of investment for each country and the sectors in which they have invested. 


\section{Macrothink

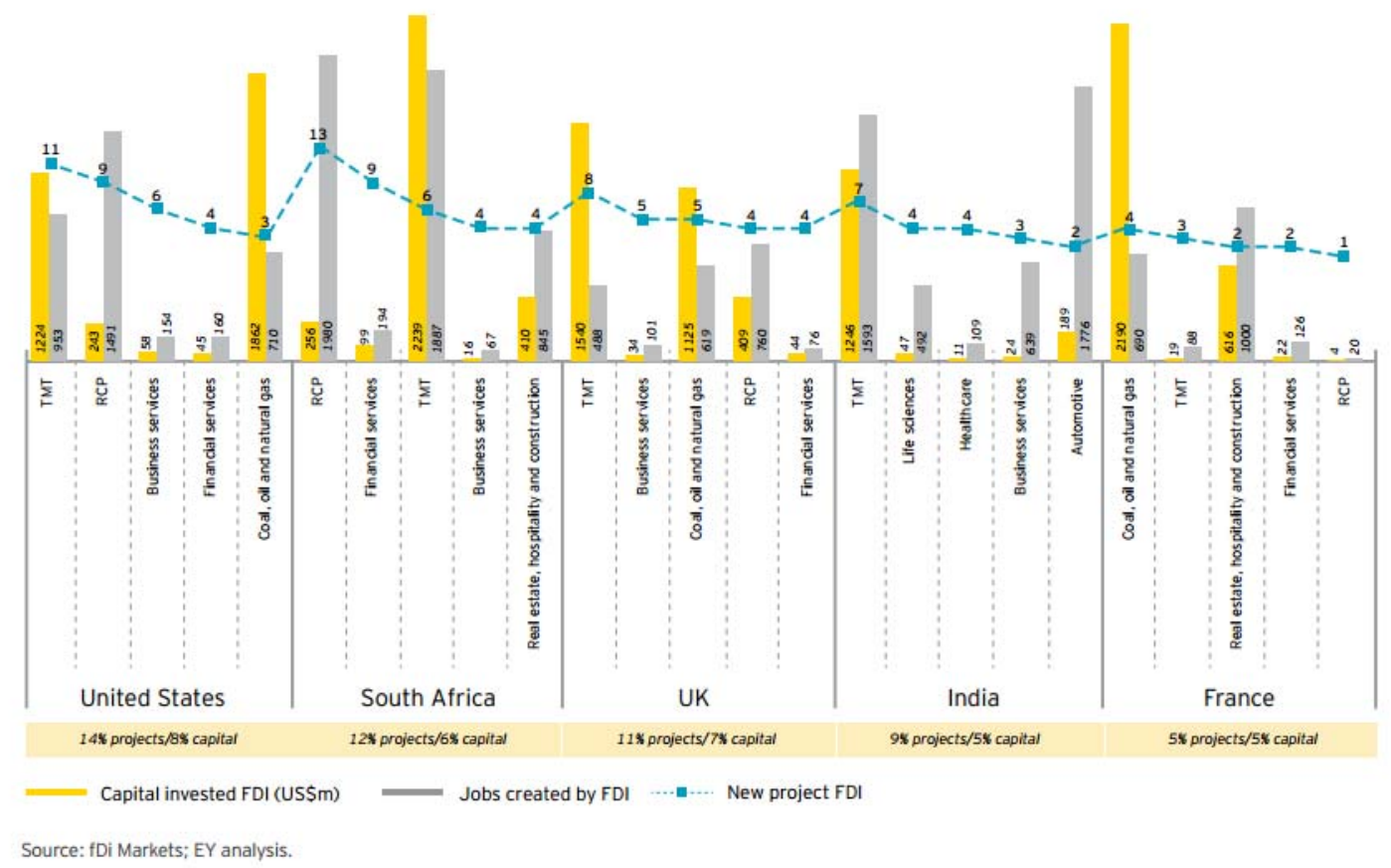

Exhibit 40. FDI Sources

Source: Government, 2014.

\subsection{Funding from Lagos State}

The Lagos State Government was considered to be the fallback funding source if there were any funding deficiencies after soliciting funds from foreign direct investment and foreign aid. However, the state government was also considered the last available choice to support additional financing because it could be risky and unreliable to depend on state administration. The Lagos State proposed Budget for 2014 contains a total of \$2,720,502,176 (San, 2013). The proposed budget also has recurrent expenditures of $\$ 1,303,695,487$ and capital expenditures of \$1,416,806,689 (Ibid.). In addition, the budget of 2014 "established a zero deficit financing requirement (Lagos, 2014)." The budget is subdivided into sectors, and a certain portion of this money would be utilized to maintain, develop or reinstate urban development projects for the State of Lagos. These sectors are: general public service, public order and safety, economic affairs, environmental protection, housing and community amenities, health, recreation, culture and religion, education and social protection (San, 2013). The largest portion of the budget was allocated to economic affairs with $32.68 \%$ of the proposed 2014 budget. The smallest percentage of the budget went to social protection which was $0.5 \%$ of the proposed budget (San, 2013; Lagos, 2014). As was noted previously, the study team's urban environmental sectors did not exactly match the budget's sectors. Hence, it was discussed among the entire Lagos urban environmental management project team what sectoral group projects fall under which sectors of the Lagos budget. Finally, the funds from the budget were distributed among the sectoral groups by analyzing the groups' additional 


\section{Macrothink}

financial needs from the grant applications and the available sectoral financing for each of them from the budget.

\subsection{Analyzing Lagos State Budget Data}

The sectoral groups were asked to identify their projects and connect them to corresponding sectors that were present in the 2014 proposed budget of Lagos, so that the teams would be able to utilize those funds for the additional amounts needed for their respective projects. Most of the groups were able to formulate their financial strategy by soliciting funds from foreign aid agencies and foundations and, therefore, could refer to the foreign aid database for any verification of possible funding. Additionally, it was decided that only $2 \%$ of the money allocated to each sector in the 2014 budget could be allocated to the proposed projects, because the entire state budget would not be completely dedicated to urban environmental management. This conclusion was reached by studying the budgetary allocation of American states. For example, the state of Ohio had a 2014 budget of \$121 billion, out of which $\$ 2.4$ billion was utilized for undertaking new development projects in the state (Office of Budget and Management, 2015).

Therefore, the amount of money allocated to each sectoral group was calculated by taking $2 \%$ of the amounts allocated to the corresponding sectors in the budget. This money was then split up among the individual projects according to their respective funding deficiencies as specified in the grant applications.

After the calculation of the amount of additional funds needed by each group from the grant application analysis, the next step was to generate the amount of funds available from the Lagos State budget over the 5 years of the plan. It was assumed that the budget would remain nearly constant throughout the plan time period. As stated previously, only $2 \%$ of the sectoral amounts in the budget were taken into consideration for calculating the availability of funds for each project from the state budget. These figures are shown in the third column of Exhibit 41 below. 


\begin{tabular}{|l|l|l|l|l|l|}
\hline Budget & $\begin{array}{l}\text { Amount } \\
\text { Allocated }\end{array}$ & $\begin{array}{l}\text { Funds } \\
\text { Available }\end{array}$ & $\begin{array}{l}\text { Available } \\
\text { Amount/ } \\
\text { Project/ } \\
\text { Year }\end{array}$ & $\begin{array}{l}\text { Corresponding } \\
\text { Sectoral } \\
\text { Groups }\end{array}$ & $\begin{array}{l}\text { Total Funding } \\
\text { Available }\end{array}$ \\
\hline $\begin{array}{l}\text { General Public } \\
\text { Service }\end{array}$ & $554,445,184$ & $11,088,904$ & $\$ 246,420$ & Energy & $1,968,406$ \\
\hline $\begin{array}{l}\text { Public Order \& } \\
\text { Safety }\end{array}$ & $99,459,851$ & $1,989,197$ & 66,306 & Water & $1,704,192$ \\
\hline $\begin{array}{l}\text { Economic } \\
\text { Affairs }\end{array}$ & $885,457,462$ & $17,709,149$ & $1,180,609$ & $\begin{array}{l}\text { Poverty } \\
\text { Alleviation }\end{array}$ & $2,317,699$ \\
\hline $\begin{array}{l}\text { Environmental } \\
\text { Protection }\end{array}$ & $219,793,700$ & $4,395,874$ & 175,834 & $\begin{array}{l}\text { Sewage and } \\
\text { Solid Waste }\end{array}$ & $2,934,520$ \\
\hline $\begin{array}{l}\text { Housing \& } \\
\text { Community } \\
\text { Amenities }\end{array}$ & $279,597,245$ & $5,591,945$ & 159,769 & Transportation & 676,825 \\
\hline Health & $209,198,081$ & $4,183,962$ & 139,465 & Industry & $1,320,075$ \\
\hline $\begin{array}{l}\text { Recreation } \\
\text { Culture \& } \\
\text { Religion }\end{array}$ & $19,264,630$ & 385,293 & $25,686.17$ & & \\
\hline Education & $428,347,595$ & $8,566,952$ & 571,130 & & \\
\hline $\begin{array}{l}\text { Social } \\
\text { Protection }\end{array}$ & $13,644,868$ & 272,897 & 0 & & \\
\hline Total & $2,709,208,615$ & $54,184,172$ & & & \\
\hline
\end{tabular}

\section{Exhibit 41: Available Funds from the Lagos State (US\$)}

Source: Compiled by chapter authors.

\subsection{Final Results}

The final results obtained through the calculations were analyzed to ensure that all the financial demands of the projects were met, and it was concluded that there was enough funding available from Lagos State to meet the additional funding requirements (See Exhibit 42 below). The sectoral groups had formulated their funding strategies well by soliciting most of the funding from private corporations and foreign aid, so that they would not have to depend heavily on the government for funding, in order to avoid risks of ineffective implementation. 


\begin{tabular}{|c|c|c|c|c|c|c|}
\hline Sectoral Groups & Year 1 & Year 2 & Year 3 & Year 4 & Year 5 & Total \\
\hline \begin{tabular}{|l|l|} 
Energy Need & \\
\end{tabular} & $2,078,612$ & 340,544 & 315,942 & 385,317 & $1,801,023$ & $4,921,440$ \\
\hline $\begin{array}{l}\text { Available State } \\
\text { Funds }\end{array}$ & $1,968,406$ & $1,968,406$ & $1,968,406$ & $1,968,406$ & $1,968,406$ & $9,842,033$ \\
\hline $\begin{array}{l}\text { Industry } \\
\text { Need }\end{array}$ & 145,800 & 0 & 0 & 0 & 0 & 145,800 \\
\hline $\begin{array}{l}\text { Available State } \\
\text { Funds }\end{array}$ & $1,320,075$ & 0 & 0 & 0 & 0 & $1,320,075$ \\
\hline $\begin{array}{l}\text { Poverty } \\
\text { Alleviation } \\
\text { Need }\end{array}$ & 402,326 & 258,476 & 258,476 & 258,476 & 205,844 & $1,383,600$ \\
\hline $\begin{array}{l}\text { Available State } \\
\text { Funds }\end{array}$ & $2,317,699$ & $2,317,699$ & $2,317,699$ & $2,317,699$ & $2,317,699$ & $11,588,499$ \\
\hline $\begin{array}{l}\text { Sewage and } \\
\text { Waste Need }\end{array}$ & 23,621 & 21,928 & 23,621 & 21,928 & 42,900 & 134,000 \\
\hline $\begin{array}{l}\text { Available State } \\
\text { Funds }\end{array}$ & $2,934,520$ & $2,934,520$ & $2,934,520$ & $2,934,520$ & $2,934,520$ & $14,672,603$ \\
\hline $\begin{array}{l}\text { Transportation } \\
\text { Need }\end{array}$ & 43,721 & 30,480 & 40,190 & 15,006 & 0 & $129,400.00$ \\
\hline $\begin{array}{l}\text { Available State } \\
\text { Funds } \\
\end{array}$ & 676,825 & 676,825 & 676,825 & 676,825 & 676,825 & $3,384,128$ \\
\hline Water Need & 50,000 & 62,000 & 136,740 & 136,740 & 136,740 & 522,220 \\
\hline $\begin{array}{l}\text { Available State } \\
\text { Funds }\end{array}$ & $1,704,192$ & $1,704,192$ & $1,704,192$ & $1,704,192$ & $1,704,192$ & $8,520,960$ \\
\hline
\end{tabular}

Exhibit 42: Funding Availability and Requirements Comparison

Source: Compiled by chapter authors.

Although financing development has become easier since the onset of globalization, it is critical to understand which sectors are to be prioritized for financing urban development, especially urban environmental management, in order to safeguard public welfare. Lagos, like the rest of Nigeria, is in need of a controlled flow of finances to achieve success in the various sectors of urban development. The role of the financial group in this study team was to find as much financing available for a 5-year period through foreign and domestic sources. The group thus successfully identified these sources by in-depth research of foreign aid opportunities and budgetary constraints along with the potential of FDI. However, the research was based on a set of assumptions that required each sectoral group to anticipate a certain level of foreign direct investment and foreign aid based on how much each sector received in the past 5 years. 


\section{Conclusion}

The intent of this project was to bring the contemporary thinking and practice of Urban Environmental Management to the solution of real problems in a major city in a developing country of Africa. The exercise, then, was to replicate as much as possible the conditions under which a team of expatriate consultants would operate in this context so that they could develop solutions that fit the circumstances they would likely find as professional planners working on such projects for international development banks (e.g., the World Bank, the Asian Development Bank, the Inter-American Development Bank or the African Development Bank), multilateral donors in the United Nations system such as the United Nations Development Program, or the numerous bilateral donors of the developed countries, which are primarily known by the alphabet soup of their initials. Major donor countries include the United States, Japan, Canada, Australia, United Kingdom, Germany, France, the Netherlands, Switzerland, Sweden, Denmark, Norway, Finland, Italy, Belgium and Spain. Consulting firms operating internationally on projects these institutions and countries fund come not only from the donor countries named, but increasingly from countries such as Brazil and India as well, and the staffs of experts they provide often come from a number of the countries named (Edelman, 2014).

In this working environment, it was instructive for the students to formulate a 5-year plan of solutions to the environmental problems and issues they faced rather than to be told how to solve them. This expanded their analytical skills and taught them how to utilize the limited knowledge and resources available to come up with implementable solutions for the benefit of the population of Mysore. They learned that such skills are transferable to other projects, and they gained a greater appreciation of the skill set that they are developing as planners. Bringing the reality of development to the classroom and asking students to confront it gives them an appreciation of professional practice that the study of theory alone does not. Thus, this project has attempted not only to expand the education of planning graduate students, but also to provide a meaningful contribution to planning pedagogy (Edelman, 2015).

\section{References}

Adejare, Q. A., Nwilp, P. C., Olusina, J. O., \& Opaluwa, Y. D. (2011). A study of ferry service route network in Lagos Lagoon-Nigeria using graph theory. Journal of Geography and Regional Planning, 4(6), 326-337

Adelere, E.A, Adetinuke, A., Omolaraeni, O. (2014). Performance characteristics of pollutants along the longitudinal profile of a subsurface flow constructed wetland domestic sewage treatment plant in the University of Lagos, Nigeria. Journal of Water Resource and Protection, 6, 104-113.

Adenikinju, A., Abiola, A., Saheed, O. (2013, May 29). Future Electricity Outlook for Lagos State [PowerPoint Slides], Retrieved December 9, 2014, from http://www.naee.org.ng/files/Akande\%20and\%20saheed.ppt

African Development Bank Group. (2014). Nigeria. Retrieved from http://www.afdb.org/en/countries/west-africa/nigeria/ 
Again, Fidelity Bank Partners Lagos on Power Project. (2013, Nov 4). Retrieved December 9, 2014 from http://www.thisdaylive.com/articles/again-fidelity-bank-partners-lagos-on-power-project/163 434/

Aidflows. (n. d.). Retrieved November 2, 2014 from http://www.aidflows.org/

Akabueze, M. B. (2014, July). Y2014 BUDGET 2nd Quarter Preformance. Retrieved October 4, 2014 from, Lagos http://www.lagosstate.gov.ng/mepb/LAGOS_Y2014_Q2_Budget\%20Appraisal.pdf

Akinloye, Lagun. "Nigeria: The Need to Prepare for a Rainy Day." Think Africa Press. N. p., 18 Oct. 2012. Retrieved December 11, 2014.

Akute Power Limited. (n. d.). Retrieved December 9, 2014, from http://www.oandoplc.com/oando-gas-and-power/subsidiaries/akute-power-limited/

Aliyu, A. (2013, November 1). Nigeria electricity crisis: Power generation capacity expansion and environmental ramifications. Energy (Oxford), 61, 354-367.

Asomani-Boateng, R. (2011). Borrowing from the past to sustain the present and the future: indigenous African urban forms, architecture, and sustainable urban development in contemporary Africa. Journal of Urbanism, 4(3), 239-262.

Bassey, J. (2014, July 3). 14mw power to become available to Lagos as two new IPPs come on stream. Retrieved December 9, 2014, from http://businessdayonline.com/2014/07/14mw-power-to-become-available-to-lagos-as-two-ne w-ipps-come-on-stream/\#.VIeJgb5rEbg

Build Change Philippines Reconnaissance Report, 2014.

Business Day. (2009, December 29). Manufacturer's Need 2,000 MW of Electricity to Stay Afloat - $\quad$ MAN. Retrieved December 9, 2014, from http://justalternativepower.com/news/detail.php?news=11.

Business Day. Revamping Nigeria’s auto industry. January 2014.Web. 1 December 2014. <http://businessdayonline.com/2014/01/revamping-nigerias-auto-industry/\#.VIkj9IfvamE>.

Campbell, John. “This is Africa’s New Biggest City: Lagos, Nigeria, Population 21 Million,” from The Atlantic. Retrieved December 15, 2014, from http://www.theatlantic.com/international/archive/2012/07/this-is-africas-new-biggest-city-lag os-nigeria-population-25-million/259611

Chave, P., Howard, G., Schijven, J., Appleyard, S., Fladerer, F., \& Schimon, W. (2011). Groundwater Protection Zones. Water Sanitation Health, 17. Retrieved October 15, 2014, from http://www.sannati.com/SGC-Engineering-Goods-Brochure(V92012).pdf

Chiejina, Alexander. Nigeria’s Pharma imports to $\$ 789 \mathrm{~m}$ by 2018. Health \& Science. October 2014. Retrieved 1 December, 2014, from http://businessdayonline.com/2014/10/nigerias-pharma-imports-to-hit-789m-by-2018/\#VIkiio 
fvamE>

Chollar, D. (2012). Water Well Support Request from CrossWay International. CrossWay International, $\quad$ Retrieved $\quad$ October $11, \quad 2014, \quad$ from http://gocrossway.org/wp-content/uploads/2010/04/CWI-Water-Well-Support-Request.pdf

CHS Consulting Group. (2007, September). Port of Redwood city ferry terminal. Retrieved November 1, 2014, from http://www.redwoodcityport.com/Reports/Final_Report.pdf

CNBC Africa. (2014, September 1). Unlocking Nigeria's infrastructure plan [Video file], Retrieved November 8, 2014, from http://www.cnbcafrica.com/video/?bctid=3761505769001

Cooperative for Assistance and Relief Everywhere. (2012). Sustainable Solutions to Poverty, Retrieved November 18, 2014, from http://www.care.org/work/economic-development

COUNTRIES/AFRICAEXT/0. contentMDK:22692743 menuPK:258659 pagePK:2865106 piPK:2865128 theSitePK:258644,00.html

CSG. (2014). Time, speed and distance calculator. Retrieved October 21, 2014 from http://www.csgnetwork.com/csgtsd.html

De Comarmond, C. (2014, January 1). Lagos gets on its bike with recycling 'loyalty' scheme,

Department of Environment and Natural Resources, Philippines (2009). Land Administration and Management Project Phase 2. Retrieved October 22, 2014, http://lamp.denr.gov.ph/index.html

Desmond-Hellman, Susan. The Cost Of Creating A New Drug Now \$5 Billion, Pushing Big Pharma To Change. Pharma \& Healthcare. August 2013. Web. Retrieved December 1, 2014, from

http://www.forbes.com/sites/matthewherper/2013/08/11/how-the-staggering-cost-of-inventin g-new-drugs-is-shaping-the-future-of-medicine/ > .

Edelman, D (2014). Managing the Urban Environment - Mysore, India. Saarbrücken: LAP LAMBERT Academic Publishing.

Edelman, D. (2015). Managing the Urban Environment - Lagos, Nigeria. Saarbrücken: LAP LAMBERT Academic Publishing.

Eko rail's trains begin journey to Lagos. (2011, September 27). Retrieved October15, 2014, from

http://www.prnewswire.com/news-releases/eko-rails-trains-begin-journey-to-lagos-13062741 8.html

Editor. “Towards a private oil refinery market in Nigeria” Businessdayonline.com. Business Day, 8 July 2014. Retrieved November 5, 2014, from http://businessdayonline.com/2014/07/towards-a-private-oil-refinery-market-in-nigeria/

$\begin{array}{llll}\text { Encyclopedia } & \text { Britannica. } & \text { (2014). } & \text { Retrieved }\end{array}$ http://www.britannica.com/EBchecked/topic/327849/Lagos 
Enjoli Liston. (2014). Hello Nollywood: how Nigeria became Africa's biggest economy overnight, accessed $\quad$ December $\quad 5, \quad 2014$ from http://www.theguardian.com/world/2014/apr/10/nigeria-africa-biggest-economy-nollywood

Eteghe, Daniel. “Agric Yes Program: Over 300 youths empowered in Lagos.” Vanguardngr.com. Vanguard, 27 September 2012. Web. 18 November 2014 from http://www.vanguardngr.com/2012/09/agric-yes-program-over-300-youths-empowered-in-lag os/ $>$.

FAPA. (n.d.). African development bank: African carbon suppose programme [PowerPoint slides, $\quad$ accessed $\quad$ October $\quad 15, \quad 2014$ from http://www.afdb.org/fileadmin/uploads/afdb/Documents/Generic-Documents/AfDB\%20Afric an\%20Carbon\%20Support\%20Programme.pdf

Galeria - Cinema e Arquitetura: (n. d.), accessed December 11, 2014 from http://www.archdaily.com.br/br/01-40720/cinema-e-arquitetura-lagos-koolhaas/40720_40818

Globalizatation. (2014). Problems of Development Today, accessed December 1, 2014 from Globalization101: www.globilization101.org/problems-of-development-today/

Government, L. S. (n.d.). Lagos State Government. Retrieved September 19, 2014, from Ministry of Finance, Lagos State Government: http://www.lagosstate.gov.ng/entities.php?k=241

Grameen Foundation (2013). Best Practices in Mobile Microfinance, accessed November 4, 2014 from http://www.grameenfoundation.org/resource/best-practices-mobile-microfinance

Grameen Foundation (2013). Building Sustainable Business Models for Providing Financial Services to the Poor, accessed November 4, 2014 from http://www.grameenfoundation.org/resource/building-sustainable-business-models-providing -financial-services-poor

GRID - Arendal, 2011.

Habitation for the Planet, accessed November 10, 2014 from www.habitation for the planet.org

Hammer, D. A. (1989). Constructed wetlands for wastewater treatment, municipal, industrial, and agricultural. Chelsea, MI: Lewis Publishers, 39, 646-656.

http://wwwwds.worldbank.org/external/default/WDSContentServer/WDSP/IB/2014/07/23/00 0333037_20140723120936/Rendered/PDF/896130INSP0P0700Box0385286B00OUO090.pd f , accessed November 21, 2014.

Heinrich Boll Foundation, Al-Zubaidi, L., \& Luckscheiter, J. (Eds.). Perspectives: political analysis and commentary from Africa [PowerPoint slides], accessed December 11, 2014 from http://ke.boell.org/sites/default/files/perspectives_cities_3.12_web.pdf

Hejelmgaard, Kim. "Who Wins, Who Loses in World Economy," USA - The Enquirer, December 17, 2014, p. 6B. 
http://images.businessweek.com/ss/09/03/0304_difficult_cities/2.ht, accessed December 15, 2014.

HexGEAR. (2014). [Live traffic map of Lagos, Nigeria], accessed November 14, 2014 from the Traffic Chief NG website: http://www.trafficchiefng.com/fullScreenMap_page.php

Ibeh, Nnenna. “Over-dependence on oil revenue hurting Nigeria - Okonjo-Iweala.” Premium Times Nigeria. Premium Times Nigeria, 4 November 2014. Web. 15 November 2014. $<$ http://www.premiumtimesng.com/business/170573-over-dependence-on-oil-revenue-hurting -nigeria-okonjo-iweala.html>

Ibiwoye, D. (2014, February 4). Lagos jetties, abundant yet under-developed, accessed November $7, \quad 2014$ from http://www.vanguardngr.com/2014/02/lagos-jetties-abundant-yet-developed/

International Bank for Reconstruction and Development. (1970). Appraisal of Third Bangkok Port Project, Thailand. World Bank Transportation Projects Department, (46a), 1-60.

International Monetary Fund Country Report: Nigeria. Washington, D.C.: International Monetary Fund, April 2014 <http://www.imf.org/external/pubs/ft/scr/2014/cr14103.pdf>

Johnson, O., Odekoya, A., Umeh, O. (2012). Factors Influencing the Usage of Compact Fluorescent Lamps in Existing Residual Building in Lagos, Nigeria. International Journal of Energy Economics and Policy, 2(2) (63-70), accessed December 9, 2014 from www.econjournals.com/index.php/ijeep/article/download/122/101.

Kermeliotis, T., \& Ellis, J. (2014, May 30). The custom-made tricycles driving Lagos's slum waste revolution, accessed October 24, 2014, from http://edition.cnn.com/2014/05/29/business/custom-made-tricycles-lagos-waste-revolution/in dex.html?iref=allsearch.

Kopec, D.A. Ohio Environmental Protection Agency. (2007). Small subsurface flow constructed wetlands with soil dispersal system. Division of surface water. Guidance document. EPA Reference rule; OAC 3745-42.

Kriscenski, A. (2007). BITUBLOCK: Building blocks made from compressed rubbish! http://inhabitat.com/bitublock-concrete-will-be-obsolete, accessed October 17, 2014.

Labour Threatens Lagos Govt Over Opposition To Minimum Wage. (2014, May 5), accessed October 24, 2014 from http://bizwatchnigeria.ng/labour-threatens-lagos-govt-opposition-minimum-wage/

Lagos. (2012). In the Columbia Electronic Encyclopedia (6th edition.). Columbia University Press.< http://www.infoplease.com/encyclopedia/world/lagos-city-nigeria.html>

Lagos cable transit, accessed October 11, 2014 from http://www.trico-capital.com/assets/files/Trico_Slide.png

Lagos metro draws on international expertise. (2013 June), accessed November 20, 2014 from 
http://www.ekorail.net/wp-content/uploads/2012/04/IRJ-June-2013-Lagos-Metro-for-web1.p df

Lagos State Waterways Authority. (2014). Information regarding water travel in Lagos, accessed December 1, 2014 from http://web.laswa-ng.com/

Lagos. Lagos Summary of Finance, accessed December 11, 2014 from Lagos State: http://www.lagosstate.gov.ng/mepb/LAGOS_Y2014_BUDGET/037\%20Y2014\%20SUMMA RY\%20OF\%20FINANCING\%20(SOURCES).pdf

“Lagos Water Supply Master Plan” (2010). Lagos Water Corporation, accessed September 5, 2014 from http://lagoswater.org/lwc_pdf/Lagos-Water-Master-Plan.pdf

LAMATA. (2014). [Description of transportation projects currently happening in Lagos], accessed December 1, 2014 from Lagos Metropolitan Area Transport Authority website: http://www.lamata-ng.com/index.php

Laylin, Tiflin. In Habitat. "Tiny Abod Shelters Provide Humane Housing for Slum Dwellers in Just One Day”. March 2013.

Longe, E. (2011). "Groundwater Resources Potential in the Coastal Plain Sands Aquifers, Lagos, Nigeria.” Research Journal of Environmental and Earth Sciences, accessed October 12, 2014 from http://maxwellsci.com/print/rjees/v3-1-7.pdf

Makoko Floating School. Publication. Lagos: NLÉ, 2013. Makoko Floating School Project Description. NLÉ, 1 Aug. 2013. Web. 11 Nov. 2014.

Map of Lagos major road network [Image]. (n. d.), accessed November 12, 2014 from http://upload.wikimedia.org/wikipedia/commons/d/d0/Location_map_Nigeria_Lagos.png

Milshtein, Amy. "Interface Teams with the Buckminster Fuller Institute and PITCHAfrica to Bring Water to a Thirsty World, One School at a Time. | Interface Blog | Design with Purpose." Interface Blog Design With Purpose. N. p., 6 Mar. 2014, accessed December 11, 2014.

Ministry of Energy and Mineral Resources/Lagos State Electricity Board (MEMR/LSEB). (2013, September). Lagos State Government: Energy Sector Projects, accessed December 9, 2014 from http://www.lseb.gov.ng/sites/default/files/LAGOS\%20STATE\%20GOVERNMENT\%20ENE RGY\%20DEVELOPMENT\%20PROJECTS\%2015.09.13.pdf.

Mobereola, D. (2009, September). Africa's first bus rapid transit scheme, accessed October 12 , 2014 from http://siteresources.worldbank.org/EXTAFRSUBSAHTRA/Resources/DP09-Lagos-BRT.pdf

Msimire. "CCDI, AAP Scheme Seeks to Generate Power from Waste." EnviroNews Nigeria (29 July 2013): n. page. EnviroNews Nigeria. MS \& Associates, accessed December 11, 2014.

Msimire. "Lagos to Produce Gas from Dump Sites." EnviroNews Nigeria 23 Aug. 2012: n. 
page. Print.

MTR. (2014). [Hong Kong's public transportation], accessed October 28, 2014 from http://www.mtr.com.hk/en/customer/tourist/index.php

Nairaland (Ed.). (2014). Ideas for solving traffic congestion in Lagos, accessed December 1, 2014 from

Nairaland

Forum:

http://www.nairaland.com/1102572/ideas-solving-traffic-congestion-lagos

National Population Commission (NPC), \& ICF International. (2013). Nigeria demographic and health survey [PowerPoint slides], accessed December 1, 2014 from http://dhsprogram.com/pubs/pdf/FR293/FR293.pdf

NBC reassures on waste recovery, recycling, accessed October 14, 2014, from http://dailyindependentnig.com/2014/03/nbc-reassures-on-waste-recovery-recycling/

National Planning Commission (2004) National Economic Empowerment and Development $\begin{array}{llll}\text { Strategy, } & \text { accessed } & \text { October } & 10,\end{array}$ http://web.ng.undp.org/documents/NEEDS/NEEDS.pdf

Nigeria, D. i. (n.d.). UKAid, accessed November 11, 2014 from www.gov.uk

OECD. (2011). Country Programmable Aid, accessed December 5, 2014 from www.oecd.org.

"NLE's Floating School Casts Anchor in Lagos Lagoon." Dezeen NLEs Floating School Casts Anchor in Lagos Lagoon Comments. Dezeen, 25 Mar. 2014. Web.

NLE. Lagos water communities’ project, 2012. http://nleworks.com, accessed December 11, 2014.

Obi E, Agbasi PU, Ezejiofor NA, Maduagwuna C, and Orisakwe OE. Safety warnings and first aid instructions on Nigerian traditional herbal remedies: are they adequate. World Journal Medicine Science (2006); 1:108-111.

Office of Budget and Management. State of Ohio Budgets at http://www.obm.ohio.gov/Budget/ accessed January 14, 2014.

Ogujiuba, K., and Obiechina, M. E. (2011). Financial Sector Reforms in Nigeria: Issues and Challenges. International Journal of Business and Management.

Oketola, A.A. and Osibanjo, O. (2009). Estimating sectoral pollution load in Lagos by industrial pollution projection system (IPPS): Employment versus output. Toxicol. Environ. Chem., 91, 799-818.

Oshikoya KA, Senbanjo IO, Njokanma OF, and Soipe A. Use of complementary and alternative medicines for children with chronic health conditions in Lagos, Nigeria. BMC Complement Altern Medicine (2008) 8:66

Otitoju, T. Individual Attitude of Recycling of Municipal Solid Waste in Lagos, Nigeria. American Journal of Engineering Research (AJER), 3 (7), 78-88, accessed October 21, 2014, from http://www.ajer.org/papers/v3(7)/L0377888.pdf 
Our Mission. (2014, January 1), accessed December 5, 2014 from http://wecyclers.com/?page_id=20

Pharmaceutical Business Review. Julphar breaks ground on \$32m Algerian facility. May 2012. Web. 11 December 2014. $<$ http://manufacturing.pharmaceutical-business-review.com/news/julphar-breaks-ground-on-3 2m-algerian-facility-150512>.

"Press Release: Unilever's first oil processing plant will drive fully traceable sustainable palm oil.” Press.unilever.com. Unilever, 3 July 2013. Web. 10 November 2014. $<$ http://www.unilever.co.id/media-centre/pressreleases/2013/Unilever-To-Build-New-Indones ian-Palm-Oil-Processing-Plant.aspx $>$

Projects, accessed October 24, 2014 from http://www.serac.org/projects\}

Recycling as a Ramification Business in Lagos. (2012, November 5), accessed October 24, 2014 from http://makerfaireafrica.com/2012/11/05/recycling-as-a-gamification-business-in-lagos/.

SAN, M. B. (2013, October 30). Y 2014 Approved Budget Summary Position - Expenditure Concept. Retrieved from Lagos State Goverment: http://www.lagosstate.gov.ng/mepb/LAGOS_Y2014_BUDGET/002\%20Y2014\%20BUDGE T\%20SPEECH\%20OF\%20H.E.pdf, accessed October 21, 2014.

Schouten, M.A.C., Mathenge, R.W. (2010). Communal sanitation alternatives for slums: A case study of Kibera, Kenya. Physics and Chemistry of the Earth. 35, 815-822.

Scruton Marine Services. (2014, November 12). Ferry boats, accessed December 8, 2014 from http://www.scrutonmarine.com/Ferry\%20Boats.htm

Selvanavagam, R. (2012). Lagos, Nigeria - Base of the Pyramid Housing Research. Habitation for the Planet, accessed October 17, 2014. http://www.habitationfortheplanet.org/blog/2012/05/lagos-nigeria-base-of-the-pyramid-housi ng-research/

Standard Tariff for Waste Collection and Disposal Services. (2011, January 1), accessed October 24, 2014 from http://www.lawma.gov.ng/Psp Data/Tariff for Waste Collection.pdf

Streets and address map of Lagos [Map]. (n.d.) accessed December 8, 2014 from http://gis.lagosstate.gov.ng/streetmap/

Suzuki, Wataru. "Unilever targets palm oil transparency in Indonesia.” Asia.nikkei.com. Nikkei Asian Review, 9 June 2014. Web. 5 November 2014.<http://asia.nikkei.com/Business/Asean-Business-File/Unilever-targets-palm-oil-transpa rency-in-Indonesia>

Taiwan Railways Administration, MOTC. (2014 November 13). [Taiwan's public transportation], accessed November 28, 2014 from http://www.railway.gov.tw/en/

Taiwo, O. (n.d.). Challenges of Transportation in Lagos [PowerPoint slides], accessed 
November

1 ,

2014

from

http://www.unep.org/transport/pcfv/PDF/cba_june/CBA_PublicTransportationLagos.pdf

The editors of Encyclopedia Britannica. (2013, April 4). Lagos. In Encyclopedia Britannica, accessed October 2, 2014 from http://www.britannica.com/EBchecked/topic/327849/Lagos

The World Bank Group. (2014). Projects \& Operations, accessed October 27, 2024 from The World Bank website: http://www.worldbank.org/projects/P112956/lagos-urban-transport-project-2?lang=en

ThisDayLive. Nigeria’s Auto Industry Slipping away from Toyota’s Grip? May 2014. Web 1 December 2014. $<$ http://www.thisdaylive.com/articles/nigerias-auto-industry-slipping-away-from-toyotas-grip $-/ 178913 />$.

TinyHouseTalk, 2012.

Trading Economics. (n.d.), accessed December 1, 2014 from http://www.tradingeconomics.com/nigeria/foreign-direct-investment

Ugbodad, Kazeem. Dangote Invents N1.5trn in Lagos Petro-Chemical Plant. Business, Business News. $\quad$ February 2014. http://www.pmnewsnigeria.com/2014/02/10/dangote-invests-n1-5trn-in-lagos-petro-chemical -plant/.pdf.

United Nations (2014). http://www.un.org, accessed November 5, 2014.

USAID. (n. d.), accessed November 10, 2014 from www.usaid.gov.in.

USEPA. (2000). Manual. Constructed wetlands treatment of municipal wastewaters. EPA/625/R-99/010, United States Environment Protection Agency, Office of Research and Development, Cincinnati, Ohio.

Vanguard. Fashola to flag off Lagos Motor show and Auto part Expo. April 2014. Web. 1 December 2014. <http://www.vanguardngr.com/2014/04/fashola-flag-lagos-motor-show-auto-part-expo/>.

VConnect Global Services Limited (Ed.). (2014). List of ferries in Lagos, accessed October 14, 2014 from http://www.vconnect.com/lagos/list-of-ferries_c572

Wall Street Journal Online (2010). http://www.wallstreetjournalonline.org, accessed November 10, 2014.

Walt, V. (2014, June 12). Lagos, Nigeria: Africa's Big Apple, accessed October 2, 2014 from the Fortune website: http:/fortune.com/2014/06/12/lagos-nigeria-big-apple/

Water and Sanitation for the Urban Poor (WSUP). (2011). http://www.wsscc.org/sites/default/files/publications/wsup_topicbrieficommunalpublictoilets _2011.pdf, accessed November 7, 2014.

"Waterbanks |by PITCHAfrica." Waterbanks | Waterbanks by PITCHAfrica. N. p., 2004, 
accessed December 11, 2014.

Wecyclers, accessed December 5, 2014 from http://cchubnigeria.com/ventures/wecyclers/

Work on Nigeria's first urban cable car network in Lagos to begin in November. (2014, August 5), accessed December 11, 2014 from Nigerian Watch website: http://www.nigerianwatch.com/news/5010-work-on-nigerias-first-urban-cable-car-network-in -lagos-to-begin-in-november-

World Bank. (1998). Nigeria - Lagos Drainage and Sanitation Project: Report and Recommendation on Request for Inspection. http://go.worldbank.org/LQJCMUY8N, accessed November 21, 2014.

World Bank. (2010, September 2). Compact Fluorescent Light Bulbs Save Ethiopia's Rural Households Money and Energy, accessed December 9, 2014 from http://web.worldbank.org/WBSITE/EXTERNAL/

World Bank (2013) Philippines: Demographic and Health Survey, accessed October 21, 2014. http://worldbank.org/en/news/philippines-demographic-health-survey

World Bank (2013). Philippines: Land Titling Made Easy, accessed October 21, 2014. http://www.worldbank.org/en/news/feature/2011/07/20/philippines-land-titling-made-easy

World Health Organization. The Africa Malaria Report 2003. WHO/CDS/MAL/2003. 1093, WHO/UNICEF. 2003.

World Health Organization. WHO traditional medicine strategy 2002-2005. WHO, Geneva; 2002

Zhang, T., Xu, D., He, F., Zhang, Y., \& Wu, Z. (2012). Application of constructed wetland for water pollution control in China during 1990-2010. Ecological Engineering, 47, 1.

\section{Copyright Disclaimer}

Copyright for this article is retained by the author(s), with first publication rights granted to the journal.

This is an open-access article distributed under the terms and conditions of the Creative Commons Attribution license (http://creativecommons.org/licenses/by/3.0/). 